\title{
Renewable Energy Opportunities at Yuma Proving Ground, Arizona
}

AC Orrell

AR Kora

BJ Russo

JL Williamson

MR Weimar

WJ Gorrissen

DR Dixon, Program Manager

June 2010
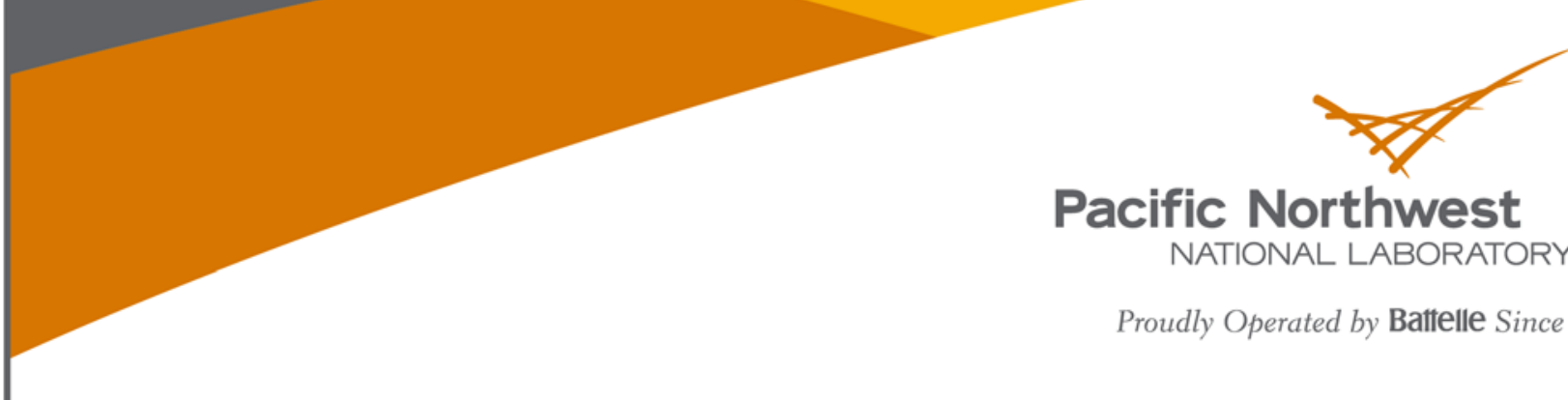

Pacific Northwest

NATIONAL LABORATORY

Proudly Operated by Battelle Since 1965 


\title{
DISCLAIMER
}

This report was prepared as an account of work sponsored by an agency of the United States Government. Neither the United States Government nor any agency thereof, nor Battelle Memorial Institute, nor any of their employees, makes any warranty, express or implied, or assumes any legal liability or responsibility for the accuracy, completeness, or usefulness of any information, apparatus, product, or process disclosed, or represents that its use would not infringe privately owned rights. Reference herein to any specific commercial product, process, or service by trade name, trademark, manufacturer, or otherwise does not necessarily constitute or imply its endorsement, recommendation, or favoring by the United States Government or any agency thereof, or Battelle Memorial Institute. The views and opinions of authors expressed herein do not necessarily state or reflect those of the United States Government or any agency thereof.

\author{
PACIFIC NORTHWEST NATIONAL LABORATORY \\ operated by \\ BATTELLE \\ for the \\ UNITED STATES DEPARTMENT OF ENERGY \\ under Contract DE-AC05-76RL01830
}

Printed in the United States of America

Available to DOE and DOE contractors from the

Office of Scientific and Technical Information,

P.O. Box 62, Oak Ridge, TN 37831-0062;

ph: (865) 576-8401

fax: (865) 576-5728

email: reports@adonis.osti.gov

\footnotetext{
Available to the public from the National Technical Information Service, U.S. Department of Commerce, 5285 Port Royal Rd., Springfield, VA 22161 ph: (800) 553-6847 fax: (703) 605-6900 email: orders@ntis.fedworld.gov online ordering: http://www.ntis.gov/ordering.htm
} 
PNNL-19543

\title{
Renewable Energy Opportunities at Yuma Proving Ground, Arizona
}

\author{
AC Orrell \\ AR Kora \\ BJ Russo \\ JL Williamson \\ MR Weimar \\ WJ Gorrissen \\ DR Dixon, Program Manager
}

June 2010

Prepared for the U.S. Army Installation Management Command Headquarters under Contract DE-AC05-76RL01830 Related Services

Pacific Northwest National Laboratory

Richland, Washington 99352 



\section{Executive Summary}

This document provides an overview of renewable resource potential at Yuma Proving Ground, based primarily upon analysis of secondary data sources supplemented with limited on-site evaluations. This effort focuses on grid-connected generation of electricity from renewable energy sources and ground source heat pumps (GSHPs). The effort was funded by the U.S. Army Installation Management Command (IMCOM) as follow-on to the 2005 Department of Defense (DoD) Renewables Assessment. The site visit to Yuma Proving Ground took place on March 25 ${ }^{\text {th }}$ and $26^{\text {th }}, 2009$.

At this time, a few renewable technologies may show some economic potential at Yuma Proving Ground. Project feasibility is based on installation-specific energy costs and projections based on accepted life-cycle cost methods (Appendix A). The most feasible opportunities are solar photovoltaics (PV) with renewable energy credit (REC) sales, and GSHPs for a narrow subset of building types. Renewable energy development at the site will require further investigation into the relationships between Yuma Proving Ground and the local utilities (Arizona Public Services (APS), Western Area Power Administration, and the Wellton-Mohawk Drainage and Irrigation District), because of complicated contractual and regulatory issues. The existence of a renewable portfolio standard (RPS) that requires a portion of the renewable energy to originate from distributed generation (DG) may allow certain renewable technologies to be feasible. However, only APS is required to satisfy the DG requirements of the RPS, and APS only serves about $2 \%$ of Yuma Proving Ground's total energy consumption (in $\mathrm{kWh}$ ) and less than $1 \%$ of the average power (in $\mathrm{MW}$ ) demand. Therefore, only certain technologies are likely to be practical at leveraging the DG market for Yuma Proving Ground.

\section{Solar}

Solar photovoltaics (PV) were not found to be cost-effective without additional incentives. The presence of a RPS that features a DG clause creates a REC market that may allow PV systems to be economically feasible under certain conditions. The most economic solar project potential is for axis-tracking PV arrays as well as lower cost roof membrane arrays. A number of appropriate buildings for membrane arrays were identified, although a more thorough study should be conducted to explicitly identify candidate buildings. In short, although Yuma Proving Ground has some of the best solar resources of all Department of Defense locations, the access to very low cost power hampers the economic viability of these systems unless RECs sales can be leveraged. Details are given in Appendix E.

\section{Ground Source Heat Pumps}

Retrofitting existing heating, ventilating, and air conditioning (HVAC) systems with GSHPs at Yuma Proving Ground was found to be economically feasible for a limited number of buildings and GSHP configurations. Moreover, GSHPs are eligible technologies for the DG REC market. To be eligible for the DG REC market, these GSHPs will need to displace APS power. The cost-effective building types identified need to be evaluated against the projected APS load requirements, before determining the total potential of GSHPs. Detailed results are provided in Appendix D.

Other renewable technologies did not prove to be cost-effective or worthwhile to develop with current conditions and assumptions. Yuma Proving Ground does not have the necessary geothermal resources in proximity to develop economic geothermal power projects (Appendix C). In addition, 
the proposed plant size would be excessive given Yuma Proving Ground's average load. The wasteto-energy projects evaluated at Yuma Proving Ground represent marginal potential. Given Yuma Proving Ground's relatively small waste generation quantity and the low population of the surrounding area, a waste-to-energy project will be challenging unless the REC market is leveraged to improve the overall project economics. However, because the majority of Yuma Proving Ground's energy is provided by a utility not governed by the RPS and small scale waste-to-energy projects (less than $1 \mathrm{MW}$ ) are generally not feasible, waste-to-energy projects, including landfill gas, are not recommended (Appendix B). Biomass projects suffer from similar constraints regarding feedstock quantity, proper sizing, and issues surrounding access to the DG REC market (Appendix B). Lastly, the wind resource was not sufficient to justify large or small scale wind projects even when reasonable REC sales were considered (Appendix F). Table 1 summarizes these findings below.

Increasing use of renewable energy makes sense for the Army. The goal of this report is to help Army personnel make sense of renewable energy at Yuma Proving Ground.

Table 1: Summary of Promising Renewable Energy Projects at Yuma Proving Ground

\begin{tabular}{|c|c|c|c|c|c|c|c|c|}
\hline & \begin{tabular}{|c|} 
Renewable \\
Resource and \\
Technology \\
\end{tabular} & $\begin{array}{l}\text { Resource } \\
\text { Estimate }\end{array}$ & $\begin{array}{r}\text { Earliest } \\
\text { Output }\end{array}$ & Figures of Merit & \begin{tabular}{|c|}
$\begin{array}{c}\text { Financing } \\
\text { Mechanisms } \\
\text { Evaluated }\end{array}$ \\
\end{tabular} & Location--Requirements & Key Assumptions & $\begin{array}{l}\text { Next Steps } \\
\text { Comments }\end{array}$ \\
\hline 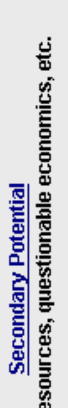 & $\begin{array}{l}\text { Utility-Grade } \\
\text { Solar Electric } \\
\text { Power Plant }\end{array}$ & $\begin{array}{c}100 \mathrm{KW}-1 \mathrm{MW} \\
\text { (or more if } \\
\text { space is } \\
\text { available) }\end{array}$ & 2011 & $\begin{array}{l}10 \% \text { IPP (Independent } \\
\text { Power Producer) } \\
\text { scenarios }=30.5- \\
35.0 \phi / \text { Wh w/ 19.8- } \\
28.2 \% \text { capacity factor } \\
\text { ECIP (Energy } \\
\text { Conservation } \\
\text { Investment Program) } \\
\text { scenarios w/ } \\
4.68 \phi / K W h=\text { negative } \\
\text { IRR, } 0.0-0.2 \text { SIR } \\
\text { (saving-to-investment } \\
\text { ratio), } 63.5-278 \text { year } \\
\text { payback }\end{array}$ & $\begin{array}{l}\text { ECIP } \\
\text { IPP }\end{array}$ & $\begin{array}{l}\text { Small scale: rooftops } \\
\text { (especially when } \\
\text { replacing rooftops), open } \\
\text { ground areas with } \\
\text { minimal shading or } \\
\text { concerns over } \\
\text { vandalism. } \\
\text { Large scale: near high } \\
\text { voltage transmission } \\
\text { lines, adequate open } \\
\text { space for array and } \\
\text { inverter system }\end{array}$ & $\begin{array}{l}\text { Proposed project will } \\
\text { not interfere with any } \\
\text { on-site systems. } \\
\text { RECs are not included } \\
\text { in analysis, but could } \\
\text { help make a project } \\
\text { economically feasible. } \\
\text { CSP (concentrating } \\
\text { solar power) } \\
\text { technologies are } \\
\text { practical to install } \\
\text { despite pre- } \\
\text { commercial status. }\end{array}$ & $\begin{array}{l}\text { PV via an ECIP is not } \\
\text { viable. Investigate } \\
\text { REC (Renewable } \\
\text { Energy Credit) } \\
\text { incentive in a PPA } \\
\text { (Purchase Power } \\
\text { Agreement) scenario. }\end{array}$ \\
\hline 高 & $\begin{array}{l}\text { Ground } \\
\text { Source Heat } \\
\text { Pump } \\
\text { (Thermal } \\
\text { Energy) }\end{array}$ & $\begin{array}{l}\text { TED (likely } \\
\text { small) }\end{array}$ & 2011 & $\begin{array}{c}1.0-2.0 \mathrm{SIR}, 7.4-14.0 \\
\text { year payback }\end{array}$ & $\begin{array}{c}\text { ECIP } \\
\text { IPP } \\
\text { UESC (Utility } \\
\text { Energy } \\
\text { Service } \\
\text { Contract) }\end{array}$ & $\begin{array}{c}\text { Adequate heat sources } \\
\text { and sinks proximate to } \\
\text { ground source heat pumps }\end{array}$ & $\begin{array}{l}\text { There are buildings } \\
\text { that require heating } \\
\text { and potentially cooling. } \\
\text { Suitable land area and } \\
\text { soil characteristics for } \\
\text { closed loop GSHPs. }\end{array}$ & $\begin{array}{l}\text { Suite surveys to } \\
\text { determine whether } \\
\text { suitable heat sinks } \\
\text { and sources exist, } \\
\text { and to provide the } \\
\text { detailed soil } \\
\text { characterization to } \\
\text { base system design. }\end{array}$ \\
\hline
\end{tabular}




\section{Table of Contents}

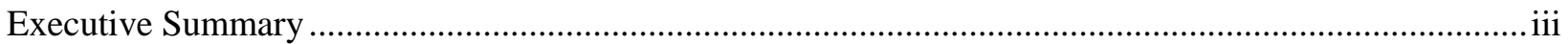

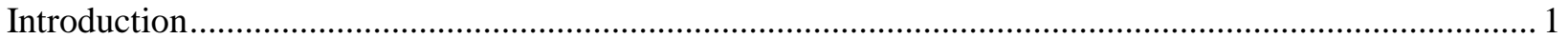

Overview of Federal and DoD Renewable Requirements ...................................................................... 3

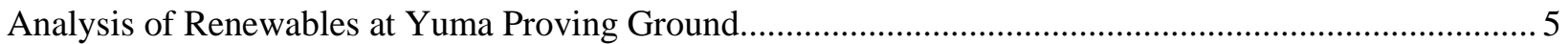

Approach for Identifying, Analyzing, and Implementing Renewable Energy Projects................... 5

Importance of Financing Mechanisms for Project Feasibility ..................................................... 6

The Political and Economic Environment for Renewables at Yuma Proving Ground.................... 7

Yuma Proving Ground Energy Characterization ................................................................ 7

State Incentives for Renewable Project Development...................................................... 8

Federal Incentives for Renewable Project Development .................................................. 9

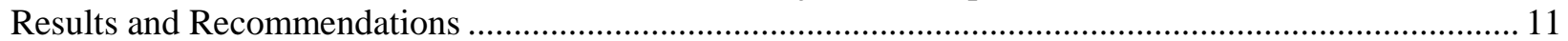

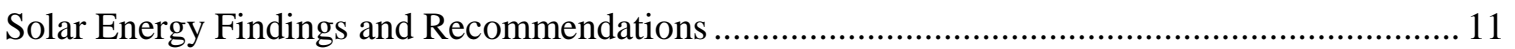

Wind Energy Findings and Recommendations........................................................................... 13

Ground Source Heat Pump Findings and Recommendations .................................................. 14

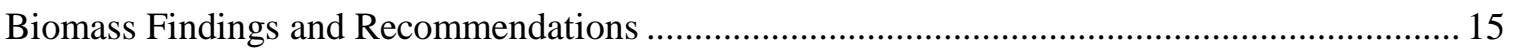

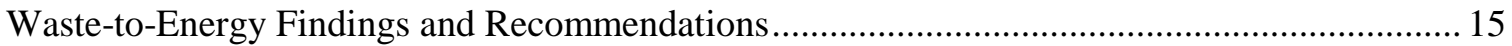

Geothermal Power Plant Findings and Recommendations ......................................................... 15

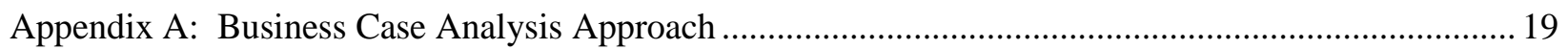

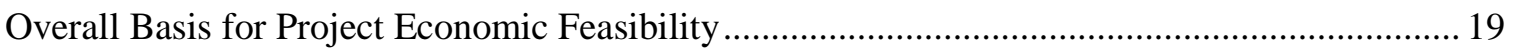

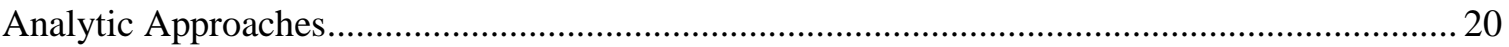

Independent Power Producer Assumptions ............................................................................ 21

Federal Incentives for Renewable Energy ………........................................................... 21

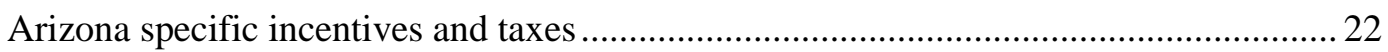

Other Independent Power Producer Assumptions ........................................................... 23

Energy Conservation Investment Projects ................................................................................ 24

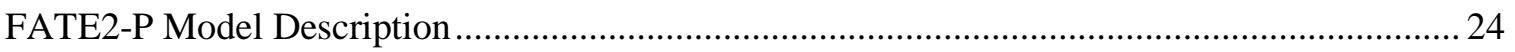

Private Ownership Rate of Return Methodology........................................................... 25

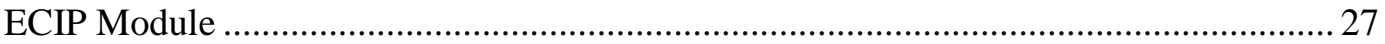

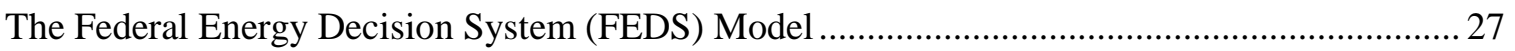

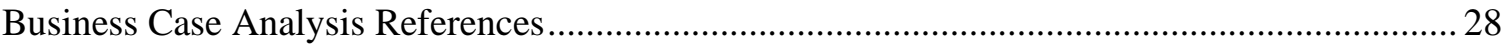

Appendix B: Analysis of Biomass and Waste-to-Energy Opportunities ................................................ 31

Biomass and Waste-to-Energy Technology ............................................................................... 31

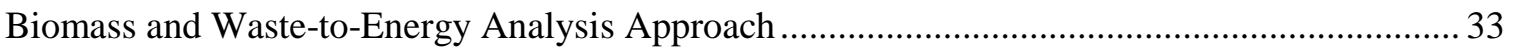

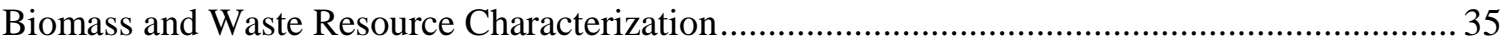

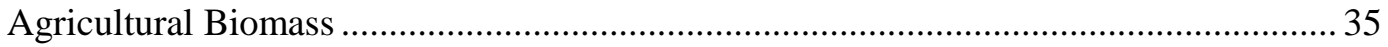




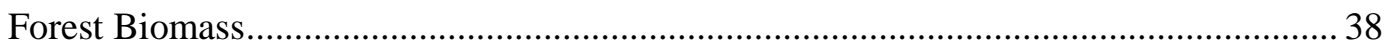

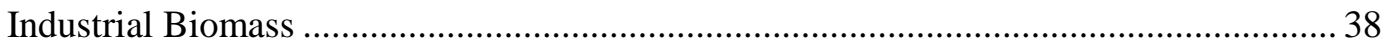

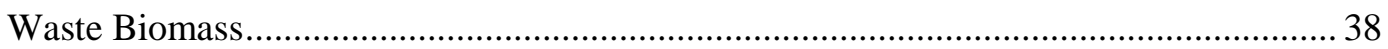

Biomass and Waste-to-Energy: Economic and Other Analysis Parameters ................................. 40

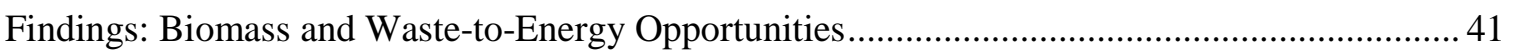

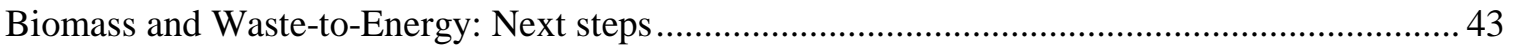

Biomass and Waste-to-Energy Sources of Information.............................................................. 43

Appendix C: Analysis of Geothermal Power Plant Opportunities............................................................ 47

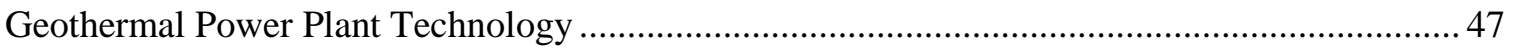

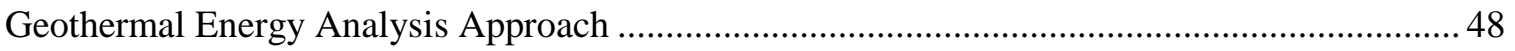

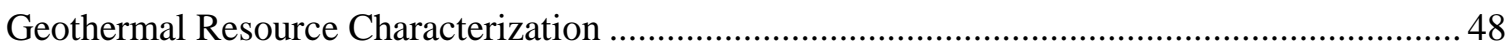

Geothermal Power Plants: Economic and Other Analysis Parameters ......................................... 51

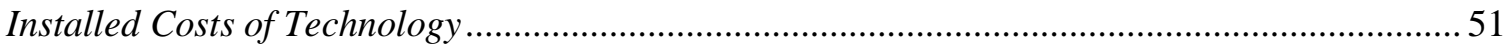

Findings: Geothermal Power Plant Opportunities ..................................................................... 52

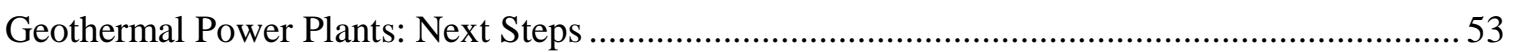

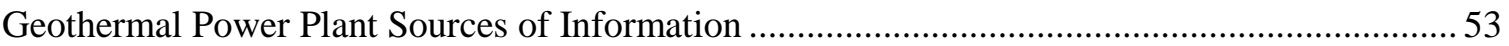

Appendix D: Analysis of Ground Source Heat Pump Opportunities....................................................... 59

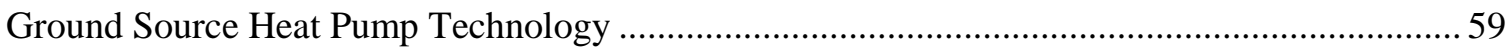

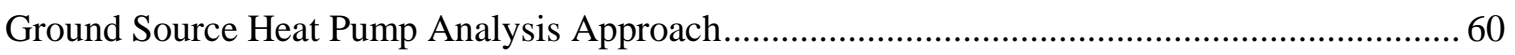

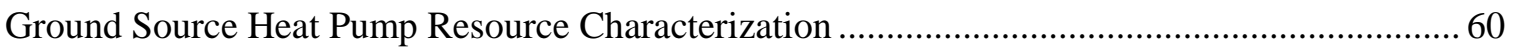

Ground Source Heat Pumps: Economic and Other Analysis Parameters ..................................... 62

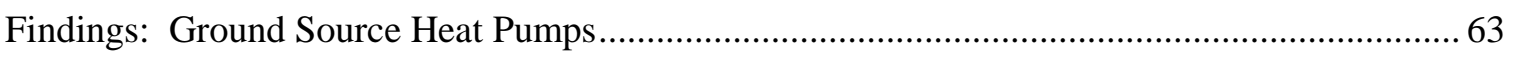

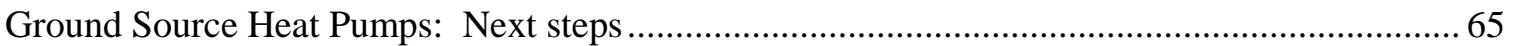

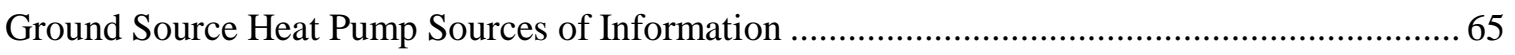

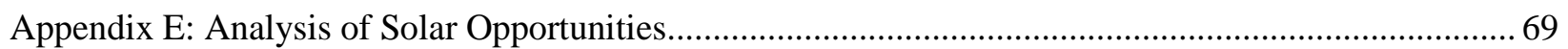

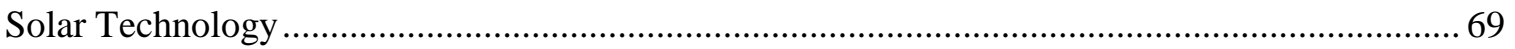

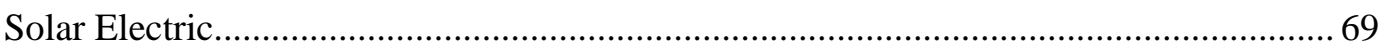

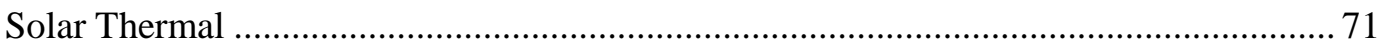

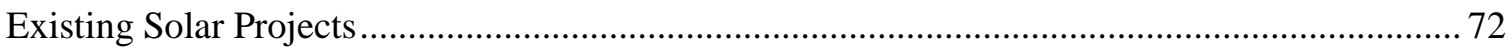

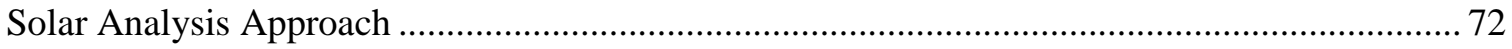

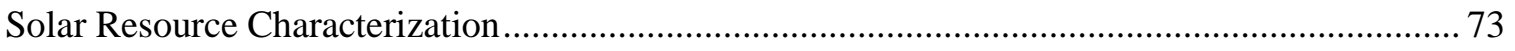

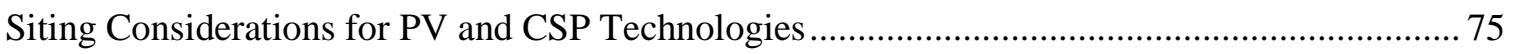

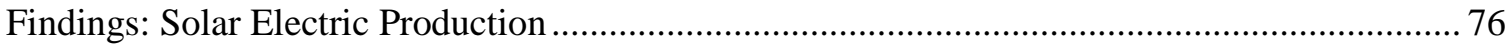

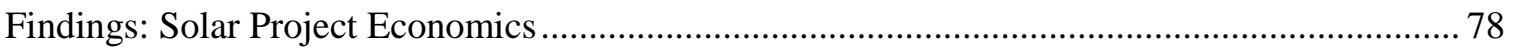

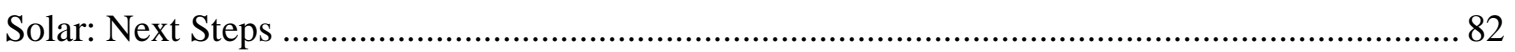

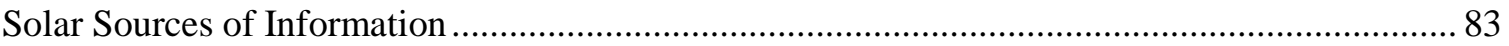

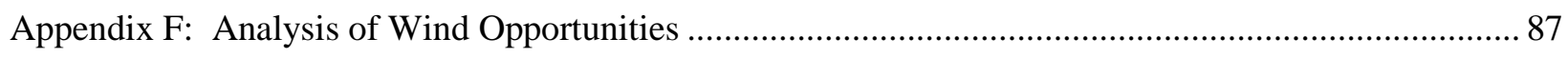

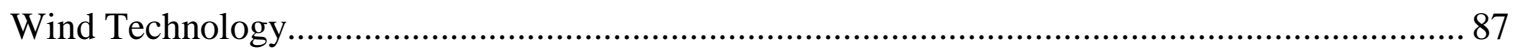




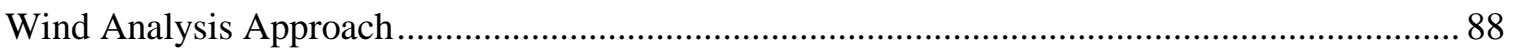

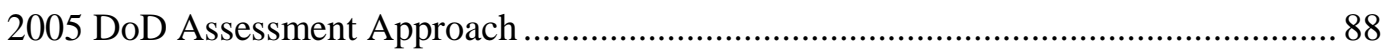

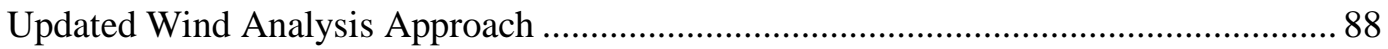

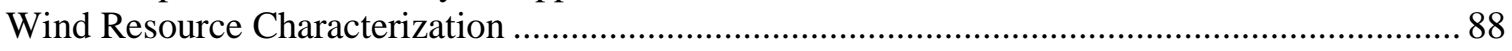

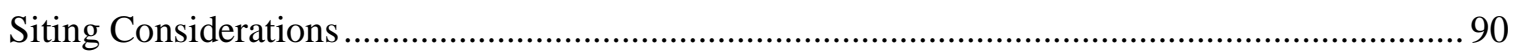

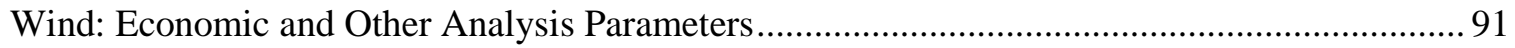

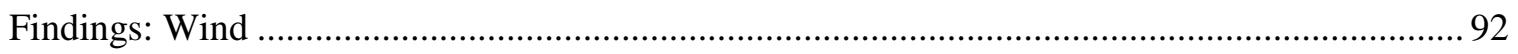

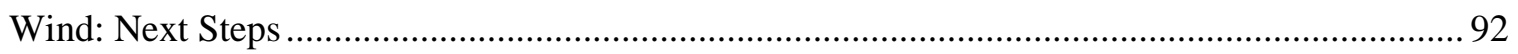

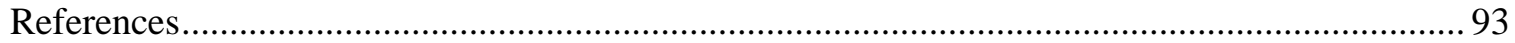




\section{Figures}

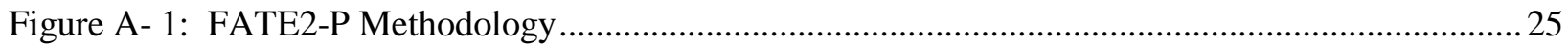

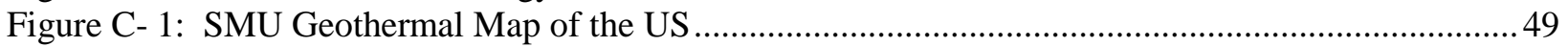

Figure C- 2: Geothermal Temperatures from the DOD Geothermal Assessment (ITSI 2003) ................. 50

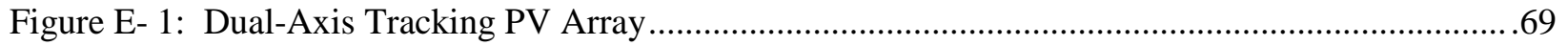

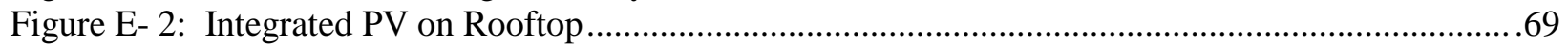

Figure E- 3: Fort Huachuca Stirling Engine Solar Dish .............................................................. 70

Figure E- 4: Transpired Solar Collector at Fort Drum..........................................................................71

Figure E- 5: Daylighting fixtures at Yakima Training Center ..............................................................71

Figure E- 6: Solar Insolation Levels for the South East Region, 3Tier FirstLook Solar Resource Map ...73

Figure E- 7: Average Daily Insolation at Yuma Proving Ground ..........................................................75

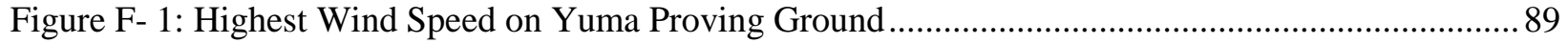




\section{Tables}

Table 1: Summary of Promising Renewable Energy Projects at Yuma Proving Ground...........................iv

Table 2: Legislated Renewable Energy Targets for DoD ................................................................. 4

Table 3: Summary of Yuma Proving Ground Renewable Energy Opportunities...................................... 11

Table 4: Economic Results for Solar PV Technologies at Yuma Proving Ground ................................. 13

Table A- 1: MACRS Depreciation Rates for Renewable Energy Projects ................................................ 22

Table A- 2: Discount Rate Assumptions in the ECIP model .............................................................. 24

Table B- 1: Crops and Biomass Production near Yuma Proving Ground ............................................... 36

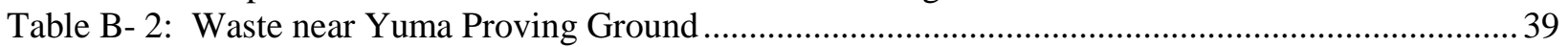

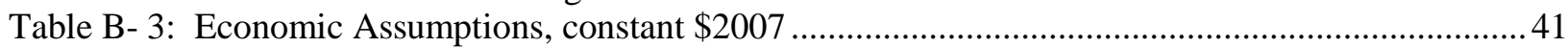

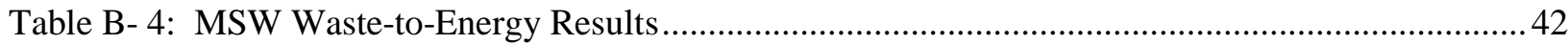

Table C- 1: Performance, Cost, and Economic Characteristics............................................................... 52

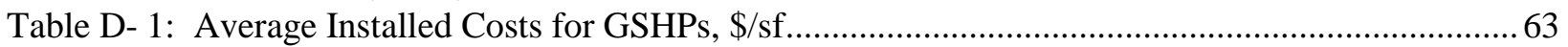

Table D- 2 : Yuma Proving Ground GSHP Opportunities ........................................................................ 64

Table E- 1: Monthly Averaged Insolation Incident on an Equator-Pointed Tilted Surface at Yuma

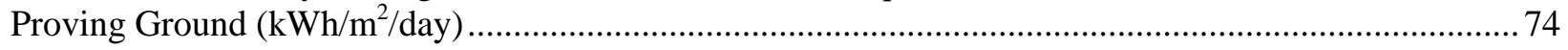

Table E- 2: Roof-Integrated Membrane PV Analysis at Yuma Proving Ground ..................................... 77

Table E- 3: Solar Electric Production by System Type at Yuma Proving Ground................................... 77

Table E- 4: Economic Results for Solar Technologies at Yuma Proving Ground.................................... 79

Table E- 5: Economic Results for Solar Technologies at Yuma Proving Ground when Displacing APS

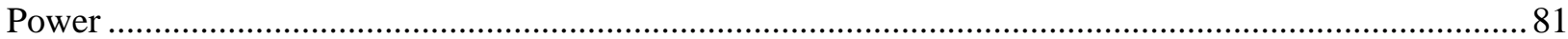

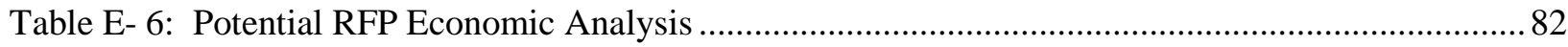

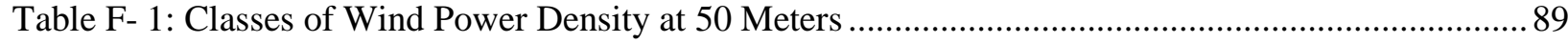

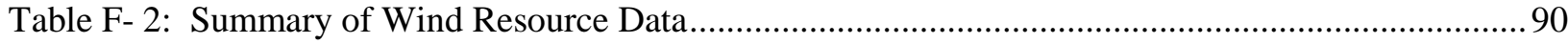

Table F- 3: Performance, Cost, and Economic Characteristics............................................................... 92

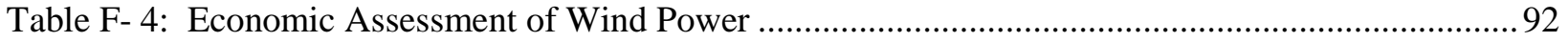




\section{Introduction}

Pacific Northwest National Laboratory (PNNL) has been directed by the U.S. Army Installation Management Command (IMCOM) to conduct detailed analyses of the potential for electricity generation at selected U.S. Army installations. The goal of the analyses is to identify economically feasible opportunities for generation of electricity from renewable resources-generation that is significant enough to warrant connection to the grid and/or to contribute in a meaningful way to the aggressive renewable energy goals of the Army and the Department of Defense (DoD).

In 2005, PNNL completed a study to identify utility-scale electricity generation opportunities at DoD installations. That study focused on solar, wind, and geothermal. A limited number of attractive large-scale commercial opportunities were identified and their implementation is now being pursued. The study also identified a number of potential smaller opportunities that needed to be investigated further before project implementation decisions could be made.

This analysis of opportunities at Yuma Proving Ground is one of a suite of analyses being conducted at Army installations as follow-on to the 2005 study. Its goal is to revisit potential renewable opportunities, updating the analysis for changes in economics, incentives, knowledge about the available renewable resource, and other factors. In addition, IMCOM has directed PNNL to evaluate the potential for biomass, waste-to-energy, and retrofitting heating and cooling systems in existing buildings with ground source heat pumps (GSHPs). Retrofitting with GSHPs is obviously not an electricity generation opportunity, but it is an opportunity for energy savings and replacement of fossil fuels across DoD. As part of the analysis, IMCOM has directed PNNL to lay out the steps necessary to implement the project opportunities that are identified.

The overall findings of this analysis are summarized in the main body of the report. The business case approach that underlies the analysis of each renewable technology is documented in Appendix A. Appendix B describes the analysis conducted on biomass and waste-to-energy technologies. Appendix C describes the geothermal power analysis; Appendix D, the GSHP analysis; Appendix E, the solar analysis; and Appendix F, the wind energy analysis. 


\section{Overview of Federal and DoD Renewable Requirements}

The Army needs to satisfy multiple goals and constraints while securing its energy suppliesfocusing upon procurement of the lowest-cost energy that meets high reliability standards and minimum vulnerability to interruption from natural or intentional causes. Overlaid on this challenge is the need to comply with a series of somewhat contradictory statutes and policies, as laid out in Table 2. These include:

- Energy Policy Act of 2005 (EPAct) Section 203. This law mandates the minimum contribution of renewable electricity to an installation's total electricity consumption. The target fractions are 3\% for FY 2007 through FY 2009, 5\% through FY 2012, and not less than 7.5\% beginning in FY 2013.

- Executive Order (EO) 13423. The Executive Order reiterates the EPAct goals; however, it uses a different basis than EPAct for measuring and crediting progress. For example, renewable thermal energy counts toward the renewable goal.

- National Defense Authorization Act (NDAA). The NDAA codifies DoD's voluntary goal of $25 \%$ by 2025 , but does not include any interim targets. Renewable thermal energy counts toward the renewable goal.

- Energy Independence and Security Act of 2007 (EISA) Section 433. EISA established two additional renewable goals for new buildings and retrofits. One requires $30 \%$ of domestic hot water to be supplied from solar energy, and the other requires all fossil fuels used in buildings to be displaced by 2030. This is not a generation goal like the others, but is important to note.

- $\quad$ Executive Order (EO) 13514. This order expands on the environmental goals of E.O. 13423 by focusing on reduction of greenhouse gas emissions. It requires Federal agencies to report greenhouse gas emissions and work with the Council on Environmental Quality (CEQ) to set reduction targets relative to a FY 2008 baseline. Implementing renewable energy technologies, which are typically less greenhouse gas intensive than traditional forms of energy production, is one strategy that sites could implement to meet the requirements outlined by this order. 
Table 2: Legislated Renewable Energy Targets for DoD

\begin{tabular}{|c|c|c|c|c|c|}
\hline & $\begin{array}{l}\text { EPAct } 2005 \\
\text { Section } 203\end{array}$ & $\begin{array}{c}\text { Executive Order } \\
13423\end{array}$ & $\begin{array}{c}\text { National } \\
\text { Defense } \\
\text { Authorization } \\
\text { Act }\end{array}$ & $\begin{array}{c}\text { Energy } \\
\text { Independence } \\
\text { and Security } \\
\text { Act }\end{array}$ & $\begin{array}{c}\text { Executive } \\
\text { Order (EO) } \\
13514\end{array}$ \\
\hline Target / Goal & $\begin{array}{l}\text { Increasing targets } \\
\text { reaching } 7.5 \% \text { of } \\
\text { electric energy from } \\
\text { renewables }\end{array}$ & $\begin{array}{c}\text { 7.5\% of electric } \\
\text { energy from } \\
\text { renewables; } 50 \% \\
\text { from new (post-1998) } \\
\text { sources }\end{array}$ & $\begin{array}{l}\text { Equivalent of } \\
25 \% \text { of electric } \\
\text { energy from } \\
\text { renewables }\end{array}$ & $\begin{array}{l}30 \% \text { of hot } \\
\text { water demand } \\
\text { from solar }\end{array}$ & $\begin{array}{l}\text { Reduction of } \\
\text { greenhouse gas } \\
\text { emissions }\end{array}$ \\
\hline Target Dates & 2013 & 2013 & 2025 & $\begin{array}{c}\text { All new } \\
\text { construction / } \\
\text { major } \\
\text { renovations } \\
\end{array}$ & 2020 \\
\hline Mandatory? & Yes & Yes & No & Yes & Yes \\
\hline $\begin{array}{l}\text { Considers thermal } \\
\text { energy "renewable"? }\end{array}$ & No & Yes & Yes & N/A & N/A \\
\hline
\end{tabular}

This assessment is primarily for renewable energy provision and retrofit applications in existing buildings. Accordingly, potential in new building construction is mentioned only in passing. The Department of Energy (DOE) is responsible for developing guidance for EPAct and EO 13423. DOE's guidelines for EO compliance, unlike EPAct, allow credit for renewable energy that reduces electricity use from thermal sources; however, it adds a requirement that at least $50 \%$ of renewable energy must come from "new” resources, those put into service after January 1, 1999.

Congress did not provide a definition of "renewable" in the NDAA language, and DOE is not responsible for establishing DoD or Army policies to achieve the goals in the NDAA. The current Army energy strategy and associated draft renewable policy takes an expansive view of renewables that encompasses thermal energy from renewable sources. As a result, the Army needs to proceed in a way that makes sense for the Army in a good faith effort to satisfy Congressional, Administration, and Pentagon mandates and directives. The expectation is that the Army will meet the stricter definitions of EPAct on its way to meeting the much higher renewable goals of the NDAA. 


\section{Analysis of Renewables at Yuma Proving Ground}

The goal of this analysis is to revisit the full suite of renewable alternatives at Yuma Proving Ground, updating the 2005 DoD analyses to reflect changes in economics, incentives, local knowledge about the renewable resources, and other factors. This study contrasts with the DoD assessment in that the latter focused on "utility-scale" renewable generating projects from wind, geothermal, and solar resources. The current study encompasses the full range of renewable energy options listed in EPAct, focused on any size project greater than $1 \mathrm{MW}$ (except for building-integrated technologies, which are much smaller). The most significant additions are assessments for biomass and waste-toenergy (WTE) resources and for use of GSHPs.

The site visits to Yuma Proving Ground took place March 25 through 26, 2009 with Doug Dixon in attendance for PNNL. Yuma Proving Ground personnel involved in the visit included Doug Waters (Chief, Master Planning), and Bryn Butler (Engineering Technician).

\section{Approach for Identifying, Analyzing, and Implementing Renewable Energy Projects}

Renewable energy resources are unlike conventional resources because the "fuel" is essentially free. However, harnessing this free resource requires substantial investment in resource exploration, characterization, and collection; project development; and ongoing maintenance and operation. A renewable resource is like purchasing a new car with a lifetime of fuel as part of the purchase agreement. First costs are much higher, but total cost may be (should be) lower over the long run.

Economic development of renewable energy depends upon:

- $\quad$ Access to a renewable resource

- Development resources

- $\quad$ Financing that is economically attractive and allowed by Federal and DoD regulations.

Each of these is critically important.

Obviously, a renewable resource has to be available and accessible to be developed. The best resources are those with the greatest potential for displacing conventional fuels or power supplies. Development cost, however, is the great equalizer, and a project based upon an excellent resource that is located many miles away may be inferior to a project based upon a lesser resource nearby. For example, an excellent wind resource far from an adequate transmission line may be less attractive than an inferior resource adjacent to a transmission line. Similarly, waste resources that could be used in a central plant may not be economic, even if they are "free," if the transportation, handling, and storage costs are greater than the cost of continued use of conventional heating fuels.

Development costs are relatively comparable for similar size projects. This is why the quality of the resource is so important—namely for the same investment, you get more out of a high quality resource than a lower quality one. But, development costs also include access to transmission capacity for shipping power for uses on-site, or over commercial networks to the site or other retail customers. The latter is a critical difference, because power shipped to other customers has to compete against the prevailing wholesale price for power from conventional resources. Typically, renewables are not competitive in these markets unless a buyer specifically demands renewable power. On the other hand, if the power can be used on-site to displace power purchased from the 
local utility, it competes against that customer's retail power price or utility rate. Because retail power prices include costs for transmission, distribution, and administrative costs, they are higher than wholesale power prices and make competing renewable projects more attractive economically.

It is important that economic analyses of renewable energy opportunities use realistic data on avoided energy costs, project costs, and available incentive funds, if any. A common analytic mistake is the use of average cost per kWh-the so-called "blended" rate. Using the blended rate will lead to inaccurate results when the renewable resource is intermittent (like wind and solar) because intermittent resources cannot be guaranteed to reduce peak demand. Even non-intermittent resources may not result in reduced peak demand because of periodic maintenance shutdowns and unscheduled outages. The economic analyses in this report use only the energy component of the power bill to evaluate intermittent resources, which is admittedly conservative. The blended rate is used for analysis of base-load resources.

Additionally, the installation's utility may impose a standby or other fee in the face of a major on-site generation project that needs to be reflected in the project's cost calculation. The analyses conducted here make no assumptions regarding standby charges, because those are typically assessed on a project-by-project basis.

The economic analyses in this report used two perspectives: Energy Conservation Investment Program (ECIP) funding and third-party financing. Use of appropriated funds via ECIP is the leastcost project finance option. However, incentives available to private owners of renewables can offset this advantage. As a result, these two evaluations effectively bracket reasonable project development costs and resulting power prices. Under the third-party arrangement, power is sold through a contract that is commonly called a power purchase agreement or PPA. This analysis assumed that an internal rate of return (IRR) of $10 \%$ is the minimum required to attract a third-party developer. The ECIP analyses assumed projects were not cost-effective if the savings-to-investment ratio (SIR) was less than 1.0.

\section{Importance of Financing Mechanisms for Project Feasibility}

Financing is a critical determinant of development costs because the high first costs are sensitive to financial factors such as incentive payments, tax breaks, and interest rates. Incentive payments and tax breaks reduce first costs, lowering both the overall project cost and interest costs. Because financing is so critical, project economics (payback rates, life-cycle costs, etc.) constitute the best initial screen for project potential. This screen needs to reflect various financing alternatives, which in turn helps energy managers decide on the best project development approach.

The 2005 DoD Renewables Assessment focused on wind, solar and geothermal power production under the assumption these were the lowest-cost and most available resources on DoD lands. The study was also focused on "utility-scale" projects on the premise that if a good renewable resource exists at a site, it should be developed to its maximum potential. This study also focuses on developing resources to their maximum potential, and does not typically analyze projects smaller than $1 \mathrm{MW}$. These large projects typically exceed any realistic expectation for appropriated funding, so the assessments focused on commercial (third-party) development of projects. Besides funding limitations, there are other reasons that these large projects should be implemented by third-party investors - under current DoD philosophy, energy resource development, ownership, operation, and maintenance is not a core DoD mission and should be left to the private sector. In addition, private developers value renewable energy credits (RECs) more highly than the Army does. As a result, 
letting the developers retain the RECs will reduce the cost of energy to the installation if the developer is selling power from the project to the site.

\section{The Political and Economic Environment for Renewables at Yuma Proving Ground}

\section{Yuma Proving Ground Energy Characterization}

Yuma Proving Ground obtains its electricity from two sources: Arizona Public Service Company (APS) and the Western Area Power Administration (WAPA) via the Wellton-Mohawk Irrigation Drainage District (WMIDD). The Western Area Power Administration (WAPA) is a Federal power marketing administration (PMA) that sells power from Federally-financed hydropower projects via an allocation process. Yuma Proving Ground has a WAPA allocation that provides the installation with a fixed amount of power (the allocation) at a set price, while the WMIDD distributes that power. Typically, power from PMAs is low-cost, as is the case with power from WAPA. The low cost power Yuma Proving Ground receives through some of its allocations with WAPA do not provide for all of Yuma Proving Ground's electricity needs. As a result, it has to obtain so-called "supplemental" power from WAPA via the WMIDD and, to a lesser extent, APS (Arizona Public Services). This supplemental power is typically priced at wholesale power rates, and thus, is much more expensive. In terms of energy savings and electricity displacement, reducing purchases of this supplemental power are much more economic than displacing power derived from WAPA allocations or other long-term supply contracts. Because WAPA allocations result in low-cost power purchases, it should be a goal to preserve this low-cost power and focus principally on the more expensive supplemental power.

The bills from WMIDD, which contain the WAPA contracted power, contained charges from three different contracts. The majority of Yuma Proving Ground's electricity, 52\%, originated from the Parker Davis Project contract and had a rate of $0.3 \$ / \mathrm{kWh}$. The "other power" contract, which is a contract between WAPA and both Yuma Proving Ground and the WMIDD, provided 40\% of Yuma Proving Ground's electricity needs and had a rate of $4.7 \$ / \mathrm{kWh}$. The CRSP (Colorado River Storage Project) contract provided 6\% of Yuma Proving Ground's electricity needs. The energy charge from this contract varied from a high of $13 \mathbb{\$} / \mathrm{kWh}$ to a low of $3 \mathbb{\$} / \mathrm{kWh}$.

In 2008, APS provided about 2\% (930 MWh during FY08) of Yuma Proving Ground's energy needs for a group of buildings in the northern portion of the ground's territory. The average rate for the electricity provided by APS varied as a function of the net quantity of energy purchased from APS. However, the average charge for the APS energy is approximately $6.8 \mathrm{c} / \mathrm{kWh}$. The annual average

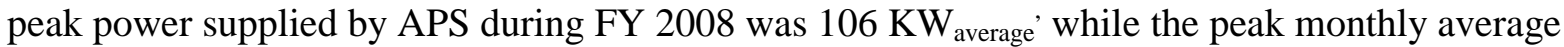
was $142 \mathrm{KW}_{\text {average }}$ in July.

In total, Yuma Proving Ground (YPG) consumed 47,870 MWh (3.9 MW average) in FY 2008 from all its utilities. Yuma Proving Ground is a summer peaking facility, with a 2008 peak consumption of 5,460 MWh and demand of 7.3 $\mathrm{MW}_{\text {average }}$ in July. The total electric bill in FY 2008 was \$1.4 million. Lastly, between 2003 and 2008, Yuma Proving Ground’s electricity consumption increased by 23\%.

FY 2008 blended electric costs averaged about 2.9\$/kWh, which is a remarkably low rate. This average value was used for base-load renewable energy resources, which are not intermittent. These resources include biomass, waste-to-energy, and geothermal power. Solar and wind are intermittent resources, and their avoided cost was calculated as the weighted average cost of electricity (not 
demand) during the year. The marginal value of solar derived energy was $4.7 \$ / \mathrm{kWh}$ for the WAPA derived energy and $6.8 \$ / \mathrm{kWh}$ for APS derived energy. The avoided cost for wind was determined to be equivalent to that of solar energy.

Lastly, YPG is in close proximity to Luke Air Force Base and the Marine Corps Air Station. Because of this arrangement, there may be potential for joint development of renewable resources that could be used to participate in the APS DG or other programs or to share power from a larger scale generating project. That option may be worth exploring if:

- The sites all purchase relatively expensive APS power and may be able to aggregate their consumption to justify a larger scale project such as a wind or solar array.

- The sites can combine resources (e.g., biomass or municipal waste) to allow for the construction of a larger power plant that might otherwise be uneconomic to construct.

- The sites can leverage purchasing economies of scale and make bulk purchases of renewable energy generation equipment (e.g., PV panels), as well as potential contracting and construction discounts.

\section{State Incentives for Renewable Project Development}

Arizona incentives are primarily in the form of avoided taxes. Arizona incentives include an investment tax credit for solar and wind; a reduction in property tax assessments for renewable energy production assets, except solar, which is totally exempt; and an exemption from sales tax for solar and wind.

The Arizona investment tax credit for solar and wind is limited to $10 \%$ of the installed value and $\$ 25,000$ per building or a total $\$ 50,000$ per year for two buildings. The tax incentive is currently available through 2012. The property tax exemption applies only to solar, which is completely exempt from property tax. Other renewable energy resources such as wind, waste-to-energy and geothermal are only assessed at $20 \%$ of the depreciated value to which the property tax rate is then applied annually. For the purposes of this analysis, the property tax rate was assumed to be $1 \%$. Wind and solar energy production facilities are exempt from the sales tax during construction of the facilities. Local sales tax may be exempted for these resources as well, but because it is a local option, it was not reduced in our analysis (DSIRE 2008b).

The state also has a renewable portfolio standard that may provide independent power producers with additional revenue depending on the value of the renewable energy credit (REC). The final rules require the $15 \%$ of electricity to be produced by renewable energy resources by 2025 . Of this total, $30 \%$ must come from distributed energy resources, one-half of which must be derived from residential, non-utility resources. Utilities in Arizona must purchase bundled RECs to meet the requirements of their state's RPS. Bundling means that a utility cannot simply purchase unbundled RECs, it must participate in the renewable energy project. Moreover, the purchased energy associated with the RECs must be deliverable to the Arizona grid.

Because the RECs are bundled and not sold separately in Arizona, the market value is not publicly known, and the economic analysis calculations do not include the potential sale of RECs. Most transactions are two-party, confidential deals. But the sale of RECs could provide another revenue stream for renewable energy projects in addition to the price received (or cost avoided) for the actual electricity. If RECs could be sold, they would further increase the value of the energy produced. Lastly, because of the unique nature of Arizona's distributed generation RPS requirement, RPS 
governed Arizona utilities must purchase RECs produced from within their service area. Moreover, the distributed generation RECs are a specialized REC. As a result, they are likely to be valued at a rate higher than standard RECs. Consequently, several utilities, including APS, have put forth a request for proposals for distributed generation projects to help satisfy the RPS requirements. This has created several opportunities for local renewable energy project development, which otherwise might not have of occurred. Yuma Proving Ground may be well positioned to potentially take advantage of such opportunities.

\section{Federal Incentives for Renewable Project Development}

Federal incentives for renewable energy include investment tax credits (ITC) for corporations, significantly accelerated depreciation of equipment, and production tax credits (PTC). Depreciation for most renewable energy equipment qualifies for accelerated depreciation. Available tax incentives reduce the first-year costs of qualified renewable projects. The lower first cost also reduces the amount of money that must be borrowed to develop a project and thus, the associated interest and carrying costs. The combination reduces the delivered cost of power if developed by a private party with a tax obligation. Government-owned projects do not benefit from tax-based incentives. All of the PPA analyses conducted in this report assume that the PTC and other tax credits will be available when the equipment is placed in service.

A 30\% ITC is available for photovoltaic (PV) projects, and $10 \%$ for geothermal and biomass electricity projects, with no incentive limits. The credits may be taken on equipment placed in service prior to January 1, 2017. The renewable energy PTC, originally established in 1992, provides a tax credit for each $\mathrm{kWh}$ of electricity produced. The PTC is $2.1 \mathrm{\&} / \mathrm{kWh}$ in 2007 for wind, geothermal and closed-loop biomass (biomass that is grown with the sole purpose of being used to generate energy), and can be taken for 10 years. The PTC is $1.0 \$ / \mathrm{kWh}$ for electricity produced from open-loop biomass and municipal solid waste resources, and can be taken for 5 years. Solar electricity generation has been excluded for equipment placed in service after December 2005, because of the inclusion under the investment tax credit. The PTC has been allowed to lapse and then been renewed several times. The tax basis for depreciation must be reduced by the amount of any Federal subsidy used in the financing of the eligible equipment. For solar, wind, and geothermal, the modified accelerated cost recovery system (MACRS) provides for 5-year recovery of the cost of equipment. The 5-year recovery period does not apply to biomass or WTE equipment. 


\section{Results and Recommendations}

A summary of analysis results is presented in Table 3 for Yuma Proving Ground, broken down into economically feasible (green), less favorable (yellow), or nonviable/uneconomic (red) projects. Note that for Yuma Proving Ground, no independent project was determined to be economically feasible (green) because of the low average cost of electricity and the quantity of available resources relative to the capital cost of the related renewable energy technology. Solar PV and GSHP were determined to only have secondary potential because of their dependence on REC sales, in the case of PV, or data uncertainties, in the case of GSHPs. The underlying analyses and recommendations for each of these technologies and potential projects are provided in the following subsections.

\section{Solar Energy Findings and Recommendations}

Yuma Proving Ground is blessed with a relatively high level of solar insolation (i.e., the amount of available solar radiation). However, the high capital cost of solar power technology coupled with the site's exceptionally low electricity rate makes solar energy only marginally economic. With current electricity prices, solar photovoltaic (PV) projects did not prove economic unless RECs can be sold. For the WAPA derived power, the possibility of DG REC sales is unlikely and ground-mounted fixed-grid PV, axis-tracking PV, and building-integrated / roof-mounted PV were all far too expensive for the amount of energy that could be produced. Of the technologies evaluated, axistracking PV proved to be the most economic option. See Table 4 for details. 
Table 3: Summary of Yuma Proving Ground Renewable Energy Opportunities

\begin{tabular}{|c|c|c|c|c|c|c|c|c|}
\hline & $\begin{array}{c}\text { Renewable } \\
\text { Resource and } \\
\text { Technology } \\
\end{array}$ & $\begin{array}{l}\text { Resource } \\
\text { Estimate }\end{array}$ & $\begin{array}{c}\text { Earliest } \\
\text { Output }\end{array}$ & Figures of Merit & \begin{tabular}{|c|} 
Financing \\
Mechanisms \\
Evaluated \\
\end{tabular} & Location--Requirements & Key Assumptions & $\begin{array}{l}\text { Next Steps } \\
\text { Comments }\end{array}$ \\
\hline \multirow{2}{*}{ 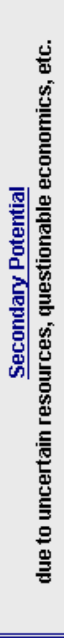 } & $\begin{array}{l}\text { Utility-Grade } \\
\text { Solar Electric } \\
\text { Power Plant }\end{array}$ & $\begin{array}{c}100 \mathrm{KW}-1 \mathrm{MW} \\
\text { (or more if } \\
\text { space is } \\
\text { available) }\end{array}$ & 2011 & $\begin{array}{l}10 \% \text { IPP (Independent } \\
\text { Power Producer) } \\
\text { scenarios }=30.5- \\
35.0 \phi / k W h \text { wi } 19.8- \\
28.2 \% \text { capacity factor } \\
\text { ECIP (Energy } \\
\text { Conservation } \\
\text { Investment Program) } \\
\text { scenarios w' } \\
4.68 \phi i k \text { h }=\text { negative } \\
\text { IRR, } 0.0-0.2 \text { SIR } \\
\text { (saving-to-investment } \\
\text { ratio), } 63.5-278 \text { year } \\
\text { payback }\end{array}$ & $\begin{array}{l}\text { ECIP } \\
\text { IPP }\end{array}$ & $\begin{array}{l}\text { Small scale: rooftops } \\
\text { (especially when } \\
\text { replacing rooftops), open } \\
\text { ground areas with } \\
\text { minimal shading or } \\
\text { concerns over } \\
\text { vandalism. } \\
\text { Large scale: near high } \\
\text { voltage transmission } \\
\text { lines, adequate open } \\
\text { space for array and } \\
\text { inverter system }\end{array}$ & $\begin{array}{l}\text { Proposed project will } \\
\text { not interfere with any } \\
\text { on-site systems. } \\
\text { RECs are not included } \\
\text { in analysis, but could } \\
\text { help make a project } \\
\text { economically feasible. } \\
\text { CSP (concentrating } \\
\text { solar power) } \\
\text { technologies are } \\
\text { practical to install } \\
\text { despite pre- } \\
\text { commercial status. }\end{array}$ & $\begin{array}{l}\text { PVvia an ECIP is not } \\
\text { viable. Investigate } \\
\text { REC (Renewable } \\
\text { Energy Credit) } \\
\text { incentive in a PPA } \\
\text { (Purchase Power } \\
\text { Agreement) scenario. }\end{array}$ \\
\hline & $\begin{array}{l}\text { Ground } \\
\text { Source Heat } \\
\text { Pump } \\
\text { (Thermal } \\
\text { Energy) }\end{array}$ & $\begin{array}{l}\text { TBD (likely } \\
\text { small) }\end{array}$ & 2011 & $\mid \begin{array}{c}1.0-2.0 \mathrm{SIR}, 7.4-14.0 \\
\text { year payback }\end{array}$ & $\begin{array}{c}\text { ECIP } \\
\text { IPP } \\
\text { UESC (Utility } \\
\text { Energy } \\
\text { Service } \\
\text { Contract) }\end{array}$ & $\begin{array}{c}\text { Adequate heat sources } \\
\text { and sinks proximate to } \\
\text { GSHPS }\end{array}$ & $\begin{array}{l}\text { There are buildings } \\
\text { that require heating } \\
\text { and potentially cooling. } \\
\text { Suitable land area and } \\
\text { soil characteristics for } \\
\text { closed loop GSHPs. }\end{array}$ & $\begin{array}{l}\text { Suite surveys to } \\
\text { determine whether } \\
\text { suitable heat sinks } \\
\text { and sources exist, } \\
\text { and to provide the } \\
\text { detailed soil } \\
\text { characterization to } \\
\text { base system design. }\end{array}$ \\
\hline \multirow{4}{*}{ 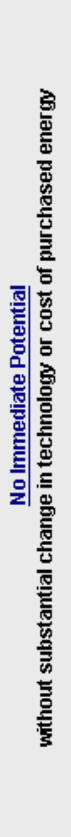 } & $\begin{array}{l}\text { Biomass } \\
\text { Generation } \\
\text { Plant }\end{array}$ & $\begin{array}{c}9.6 \text { MW installed } \\
\text { capacity at } 85 \% \\
\text { capacity factor }\end{array}$ & 2011 & $\begin{array}{c}\text { Produces electricity at } \\
12.4 \text { \$ } / \mathrm{WWh}\end{array}$ & $\begin{array}{l}\text { Appropriated } \\
\text { funds }\end{array}$ & $\begin{array}{l}\text { A } 5 \text {-acre site near major } \\
\text { rods, a utility substation, } \\
\text { water, sewage, and an } \\
\text { appropriate industrial } \\
\text { infrastructure, plus } \\
\text { feedstock storage space }\end{array}$ & $\begin{array}{l}\text { Off-site crops will be } \\
\text { available for } \$ 20 \text { per } \\
\text { ton, sufficient on-site } \\
\text { storage is available }\end{array}$ & $\begin{array}{l}\text { Verify the quantity and } \\
\text { value of crop residue } \\
\text { and the availability of } \\
\text { a suitable location for } \\
\text { the plant and } \\
\text { feedstock storage. }\end{array}$ \\
\hline & $\begin{array}{l}\text { Utility Grade } \\
\text { Wind Farm \& } \\
\text { Small Scale } \\
\text { Wind }\end{array}$ & $\begin{array}{l}1.5 \mathrm{MW} \text { installed } \\
\text { capacity at } 24 \%\end{array}$ & 2011 & $\begin{array}{c}10 \% \text { IPP scenarios }= \\
14.9 \phi / k W h \text { w/ } 24 \% \\
\text { capacity factor } \\
\\
\text { ECIP scenarios } w / \\
4.68 \% / K W h: \text { W } 24 \%= \\
\text { negative IRR, } 0.17 \\
\text { SIR, } 69 \text { year payback }\end{array}$ & $\begin{array}{l}\text { ECIP } \\
\text { IPP }\end{array}$ & $\begin{array}{l}\text { The highest annual } \\
\text { average wind speed was } \\
\text { found in the Castle } \\
\text { Dome area of the } \\
\text { installation and located } \\
\text { in proximity to } 161 \text { and } \\
69 \mathrm{~K} \text { lines. }\end{array}$ & $\begin{array}{l}\text { Proposed project will } \\
\text { not interfere with any } \\
\text { on-site systems. } \\
\text { RECs are not included } \\
\text { in analysis, but could } \\
\text { help make a project } \\
\text { economically feasible. }\end{array}$ & $\begin{array}{l}\text { Recommend putting } \\
\text { met tower in Garden } \\
\text { Canyon area to verify } \\
\text { wind resource. } \\
\text { Investigate REC } \\
\text { potential. }\end{array}$ \\
\hline & $\begin{array}{l}\text { Municipal } \\
\text { Waste-to- } \\
\text { Energy Plant } \\
\text { using } \\
\text { Combustion } \\
\text { or Gasification } \\
\text { Technology }\end{array}$ & $20-26 \mathrm{MW}$ & 2012 & $\begin{array}{c}2.92 \text { d } / \mathrm{kWh}: \\
\text { Payback: } 20 \text { years } \\
\text { SIR: } 0.6\end{array}$ & $\begin{array}{l}\text { ECIP } \\
\text { IPP }\end{array}$ & $\begin{array}{l}\text { A 5-acre site on Yuma } \\
\text { Proving Ground near } \\
\text { major roads, a utility } \\
\text { substation, water, } \\
\text { sewage, and an } \\
\text { appropriate industrial } \\
\text { infrastructure }\end{array}$ & $\begin{array}{l}\text { Adequate MSW for the } \\
\text { plant sized selected. } \\
50 \% \text { of tipping fees } \\
\text { available with MSW to } \\
\text { plant. }\end{array}$ & $\begin{array}{l}\text { Confirm waste } \\
\text { availability and } \\
\text { tipping fees. } \\
\text { Economics are highly } \\
\text { dependent upon } \\
\text { tipping fee available } \\
\text { from waste providers. }\end{array}$ \\
\hline & $\begin{array}{l}\text { High } \\
\text { Temperature } \\
\text { Geothermal } \\
\text { Generation }\end{array}$ & $15 \mathrm{MW}$ & 2011 & 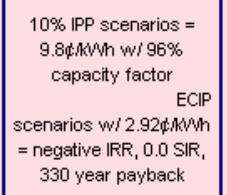 & $\begin{array}{l}\text { ECIP } \\
\text { IPP }\end{array}$ & $\begin{array}{c}\text { Temperatures }>100 \mathrm{C} \text { at } \\
\text { depths less than } 3 \mathrm{~km} \text {, hot } \\
\text { water or steam flow rates }> \\
1000 \mathrm{gpm} \text {, heat flow rates } \\
>80 \mathrm{~mW} / \mathrm{m} 2\end{array}$ & $\begin{array}{c}\text { High temperatures, fluid } \\
\text { flow, and heat flows are } \\
\text { available at economic } \\
\text { depths. }\end{array}$ & $\begin{array}{l}\text { Geothermal resource } \\
\text { may be available, but } \\
\text { verification } \\
\text { equipment is too } \\
\text { costly to risk not } \\
\text { finding a valuable } \\
\text { resource }\end{array}$ \\
\hline
\end{tabular}


Table 4: Economic Results for Solar PV Technologies at Yuma Proving Ground

\begin{tabular}{||l|c|c|c|c||}
\hline & $\begin{array}{c}\text { Ground-Mounted } \\
\text { Fixed-Tilt PV }\end{array}$ & $\begin{array}{c}\text { Ground-Mounted } \\
\text { Axis-Tracking PV }\end{array}$ & $\begin{array}{c}\text { Building-Integrated } \\
\text { Roof-Mounted PV }\end{array}$ & Solar Dish \\
\hline Analyzed System Size & Greater than $250 \mathrm{~kW}$ & Greater than 250 kW & Greater than 250 kW & $25 \mathrm{~kW}$ \\
\hline $\begin{array}{l}\text { Equipment Cost } \\
\text { Assumptions (\$/kW) }\end{array}$ & $\$ 6,450$ & $\$ 7,800$ & $\$ 5,550$ & $\$ 4,700$ \\
\hline SIR & 0.178 & 0.214 & 0.199 & 0.0 \\
\hline Simple Payback (yr) & 76.1 & 63.5 & 67.7 & 278 \\
\hline $\begin{array}{l}\text { Cost of Electricity at } \\
\mathbf{1 0 \%} \text { IRR (\$/kWh) }\end{array}$ & 35.0 & 30.5 & 31.0 & 28.0 \\
\hline $\begin{array}{l}\text { Breakeven System Cost } \\
\text { at 10\% IRR (\$/kW) }\end{array}$ & $\$ 750$ & $\$ 1,090$ & $\$ 730$ & $\$ 164$ \\
\hline Variable O\&M (4/kWh) & - & - & $\$ 12$ & 2.64 \\
\hline Fixed O\&M (\$/net kW) & $\$ 12$ & $\$ 12$ & $\$ 25$ \\
\hline
\end{tabular}

The existence of an RPS with a DG carve out does provide an avenue for solar PV projects to be explored. APS, a utility that is bound by the RPS legislation, has actively sought DG proposals for the purposes of purchasing DG RECs. Because of the higher price of APS electricity and the possibility of REC sales, a PV project could be feasible as long as it displaces the relatively expensive energy provided by APS. Displacing the lower cost energy from the WMIDD/WAPA would not likely be cost-effective unless the more expensive subset of WMIDD/WAPA power (that is the energy value at $4.67 \$ / \mathrm{kWh}$ ) was displaced and the PPA resulted in a relatively low fixed energy rate, on the order of $5 \mathrm{~d} / \mathrm{kWh}$. Also, note that the previous APS request for proposal (RFP) required that DG projects must produce no less than 1,500 MWh per year, which is less than the total quantity of energy that was purchased from APS during FY08. This stipulation would have made any proposal ineligible for the previous APS RFP. A future RFP may or may not have a similar stipulation.

Solar thermal technologies were also evaluated for Yuma Proving Ground. Given Yuma Proving Ground's relatively small load, only the solar dish technology was ultimately considered. Because of this technology's relative immaturity, the site's low cost of electricity, and the high operations and maintenance (O\&M) costs of these systems, solar dishes were not found to be economically feasible. The SIR for the solar dish was 0.0 and the payback was nearly 280 years. Concentrating PV technologies are starting to become considered for utility-grade power production, but as of now, this technology is still largely pre-commercial.

Because of the area's high solar resource, Yuma Proving Ground should continue to monitor the market conditions affecting solar energy. Advances in PV technology are expected to produce less expensive solar technology, although rising demand may negate some of these advances. Rising energy rates may do the most to tip the scales in favor of solar power. Appendix E describes the detailed analysis.

\section{Wind Energy Findings and Recommendations}

The wind resource at Yuma Proving Ground does not appear to be sufficient to provide for an economically feasible wind project unless RECs can be sold. With a wind speed of $6.0 \mathrm{~m} / \mathrm{s}$, a 
commercial energy cost of $14.9 \$ / \mathrm{kWh}$ would be required to provide a $10 \%$ IRR, which is only feasible if REC sales of $10.2 \$ / \mathrm{kWh}$ could be secured. Using ECIP funding, the SIR is 0.17 and the payback is over 69 years.

Yuma Proving Ground could consider a small-scale wind project. While small-scale turbines contribute just a small amount of electricity, they may provide other benefits. Installing a wind turbine can immediately bring attention from the community to a site's commitment to renewable energy. However, given the higher capital costs per installed watt for small-scale wind turbines as compared to large-scale turbines and the low cost of energy at Yuma Proving Ground, small scale wind would not be cost-effective unless unrealistically high RECs were offered. Lastly, to be eligible as a DG REC, this turbine would likely need be installed in the northern portion of the facility that is served by APS, a utility that is bound by the RPS. It may be possible to site the infrastructure in the southern portion of the site and wheel power to the APS grid, but this introduces complication and would require analysis beyond the scope of this assessment. Also, note that the previous APS request for proposal (RFP) required that DG projects must produce no less than 1,500 MWh per year, which is less than the total quantity of energy that was purchased from APS during FY08. This stipulation would have made any proposal ineligible for the previous APS RFP. A future RFP may or may not have a similar stipulation.

Other factors to consider when deciding on whether or not to pursue a wind power project include available incentives and future costs of energy. The political and policy situation with respect to incentives is ever-changing, and new and different incentives may be available in the future. Another important consideration is that the cost of wind power is not dependent upon the cost of fossil fuels. Even a small-scale project could be a hedge against rising energy rates. This analysis is detailed in Appendix F.

\section{Ground Source Heat Pump Findings and Recommendations}

The cost-effectiveness of retrofitting existing building on Yuma Proving Ground with GSHPs was evaluated using the Facility Energy Decision System (FEDS) building energy modeling program. Because of the lack of detailed site information, the analysis was completed using a variety of standard buildings with characteristics that match what is typically found on military installations such as Yuma Proving Ground. To limit the total number of buildings being modeled, only barracks and administration buildings were analyzed. These building types were selected based on experience with GSHP projects that has shown them to be the most likely candidates for economically feasible projects.

FEDS determined that, given the environmental and geological conditions at Yuma Proving Ground, horizontal, closed-loop GSHPs are potentially cost-effective as retrofit projects. However, only a narrow set of building types and sizes with a certain combination of existing HVAC technologies were found to be economically feasible. The analysis concluded that small $\left(500 \mathrm{ft}^{2}-5000 \mathrm{ft}^{2}\right)$ administration buildings and barracks with propane/fuel oil heating and air-cooled chillers were shown to generally have the highest SIRs. This configuration of building size, use type, and conditioning technologies is uncommon, so it is important that these options be compared with the existing buildings at Yuma Proving Ground to determine whether any such situations exist on-site. The available buildings can then be use to determine whether there is a potential for GSHPs.

The feasibility of GSHPs is influenced by many factors, including energy prices, local climactic and soil conditions, as well as the characteristics of the candidate buildings. At Yuma Proving Ground, 
the climatic conditions play the most important role in determining cost-effectiveness, but, given the marginal SIRs calculated, the variability of energy pricing between the different energy suppliers that serve the installation could play an important role. This is especially true for areas served by APS because under Arizona's RPS, GSHPs are eligible technologies for REC generation, and all RECs generated by a GSHP would be the higher valued DG REC. Detailed results are provided in Appendix D.

\section{Biomass Findings and Recommendations}

The potential biomass resources near Yuma Proving Ground are crop residue, animal waste, and methane from wastewater treatment plant sludge. At this time, dedicated energy crops are not available, but could potentially be grown. The potentially available crop residue is sufficient to support a 9.6 MW plant, although this plant would be oversized for Yuma Proving Ground's needs. The potentially available animal waste is sufficient to support a $14 \mathrm{MW}$ plant, although this plant would also be oversized for Yuma Proving Ground's needs. This assumes that the animal waste (from cattle for the Yuma Proving Ground analysis) originates from feedlots. If the cattle were not located on feedlots, the cost and viability of collecting the waste would lead to an economically unviable project. Lastly, the volume of wastewater generated at Yuma Proving Ground and the surrounding area does not produce sufficient methane for an economic project. Based on the scale of typical biomass plants and the relatively small size of Yuma Proving Ground's average electrical load, biomass plants are not economically feasible at this time. Although these technologies are eligible under the RPS, the quantity of energy provided to Yuma Proving Ground from APS, the only utility that serves Yuma Proving Ground that is bound by the RPS, is too small for these technologies. See Appendix B for more details.

\section{Waste-to-Energy Findings and Recommendations}

There is one active landfill on Yuma Proving Ground in addition to two additional landfills approximately 30 miles off-site. Combined, these plants could supply 240,000 tons of waste per year, which is equivalent to $26 \mathrm{MW}$ of potential power. Typical waste-to-energy plants are on the order of tens of MW, which is well in excess of Yuma Proving Ground's average load. All waste in the area was evaluated for economic feasibility as a combustion, gasification, or plasma melting WTE project. Only combustion WTE projects were found to be economic. The smallest plant analyzed, a 21.1 MW combustion plant, was found to have an SIR of 0.6, a simple payback of 20.6 years, and an internal rate of return of 3.88\%. Projects utilizing only waste from the South Yuma Landfill showed highly unfavorable economics and thus were excluded from these results. For a worthwhile landfill gas project, the landfill must have at least 1 million tons in place, be at least 30 feet deep, receive at least 25 inches of rain annually, and be lined. Because Yuma receives only about 3 inches of precipitation per year, utilizing landfill gas as a source of renewable energy is not feasible. Detailed results are provided in Appendix B.

\section{Geothermal Power Plant Findings and Recommendations}

According to available data, Yuma Proving Ground lacks naturally occurring hot water/steam fields and elevated temperatures at economic depths (less than 3000 meters). Yuma Proving Ground also lacks sufficient heat flow rates for geothermal energy production. At this time, Yuma Proving Ground is not a candidate for utility-scale geothermal energy production. 


\section{APPENDIX A}

\section{Business Case Analysis Approach}




\section{Appendix A: Business Case Analysis Approach}

\section{Overall Basis for Project Economic Feasibility}

The renewable projects considered in this analysis need to compare favorably against the future commercial price of electricity to be purchased by the Yuma Proving Ground to be economically feasible. Yuma Proving Ground obtains its electricity from two sources: Arizona Public Service Company (APS) and the Western Area Power Administration (WAPA) via the Wellton-Mohawk Irrigation Drainage District (WMIDD). The Western Area Power Administration (WAPA) is a Federal power marketing administration (PMA) that sells power from Federally-financed hydropower projects via an allocation process. Yuma Proving Ground has a WAPA allocation, which provides the installation with a fixed amount of power (the allocation) at a set price while the WMIDD distributes that power. Typically, power from PMAs is low-cost, as is the case with power from WAPA. The low cost power Yuma Proving Ground receives through some of its allocations with WAPA do not provide for all of Yuma Proving Ground's electricity needs. As a result, it has to obtain so-called "supplemental" power from WAPA via the WMIDD and, to a lesser extent, APS (Arizona Public Services). This supplemental power is typically priced at wholesale power rates and thus, is much more expensive. In terms of energy savings and electricity displacement, reducing purchases of this supplemental power are more economic than displacing power derived from WAPA allocations or other long-term supply contracts. Because WAPA allocations result in low-cost power purchases, it should be a goal to preserve this low-cost power and focus principally on the more expensive supplemental power.

The bills from WMIDD, which contain the WAPA contracted power, contained charges from three different contracts. The CRSP (Colorado River Storage Project) contract contained two different demand charges: a seasonal CROD (contract rate of delivery) and firm transmission charge. The seasonal CROD was $\$ 4.43 / \mathrm{kW}$. The Firm Transmission charge was $\$ 1.08 / \mathrm{kW}$. In addition, there are two direct energy charges: an AHP (available hydropower) energy charge at $\$ 0.0143 / \mathrm{kWh}$ and a WRP (western replacement power) Energy charge that varied from $\$ 0.03834 / \mathrm{kWh}$ September to $\$ 0.13511 / \mathrm{kWh}$ in August. The CRSP bill ranged from \$6,000 per month to \$15,000 per month. Similarly, the Parker Davis Project Contract ranged from $\$ 6,000$ per month to $\$ 12,000$ per month. The Parker Davis Project Contract contained a demand charge of $\$ 1.45 / \mathrm{kW}$ for generation capacity and firm transmission charge of $\$ 1.08 / \mathrm{kW}$. In addition, there were two direct energy charges associated with this contract: an energy charge that was $\$ 0.00332 / \mathrm{kWh}$ and Lower Colorado River Fund Charge of $\$ 0.0045 / \mathrm{kWh}$. Although this contract had similar billing totals, the $\mathrm{kWh}$ consumed were significantly larger, ranging from just less than 1.5 million $\mathrm{kWh}$ to 3.8 million $\mathrm{kWh}$. The third contract, known as the "other power contract" contained most of the electricity charges, ranging from a low of $\$ 10,000$ in March to a high of $\$ 117,000$ in July. This contract only had a direct energy charge of $\$ 0.04686 / \mathrm{kWh}$.

The total amount of energy supplied by APS was very small (930 MWh, less than $2.0 \%$ on average) in comparison the energy supplied from WAPA via the WMIDD during FY 2008. The average rate for the electricity provided by APS varies as a function of the net quantity of energy purchased from APS. However, the average charge for the APS energy is approximately $6.8 \$ / \mathrm{kWh}$. The annual

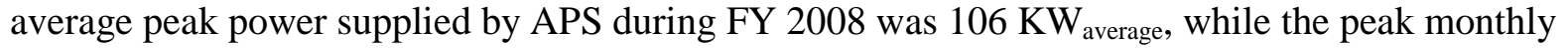
average was $142 \mathrm{KW}_{\text {average }}$ in July.

In total, Yuma Proving Ground consumed 47,870 MWh (3.9 $\mathrm{MW}_{\text {average }}$ ) in FY 2008 from all its utilities. Yuma Proving Ground is a summer peaking facility, with a 2008 peak consumption of 
5,460 MWh and demand of 7.3 $\mathrm{MW}_{\text {average }}$ in July. The total electric bill in FY 2008 was \$1.4 million. Lastly, between 2003 and 2008, Yuma Proving Ground’s electricity consumption increased by 23\%.

In summary, Yuma Proving Ground receives its electricity from a variety of contracts and providers and as a result, it has a multi-tire rate arrangement. In FY08:

- $\quad$ The AHP energy (included the CRSP contract) provided 3\% of the site's net electricity consumption at a rate of $\$ 0.0143 / \mathrm{kWh}$. AHP is the maximum amount of hydro capacity and energy that will be made available to Yuma Proving Ground on a monthly basis as determined by WAPA based on prevailing water release conditions.

- The WRP energy (also part of the CRSP contract) provided 4\% of the site's net electricity consumption at a rate of $\$ 0.03834 / \mathrm{kWh}$ in September to $\$ 0.13511 / \mathrm{kWh}$ in August. WRP is the amount of supplemental power requested by the contractor to be acquired by WAPA on behalf of Yuma Proving Ground as part of Yuma Proving Ground's CROD within a given period and paid for by Yuma Proving Ground on a pass-through-cost basis.

- The Parker Davis Project contract provided 52\% of the site's net electricity consumption at a rate of $\$ 0.00332 / \mathrm{kWh}$

- The “other power” contract provided 39\% of the site’s net electricity consumption at a rate of $\$ 0.04686 / \mathrm{kWh}$

- The APS contract provided $2 \%$ of the site's net electricity consumption at a blended rate of $\$ 0.1011 / \mathrm{kWh}$

Solar and wind renewable energy resources depend on meeting the direct energy charge, while geothermal and waste-to-energy need to compare favorably against the average avoided cost including demand charges. Solar and wind were sized to compare against the other energy charge of $\$ 0.04686 / \mathrm{kWh}$. Geothermal power and waste-to-energy needed to be sized to meet this other energy charge or accept the average avoided cost, which was $\$ 0.0292 / \mathrm{kWh}$.

All but one of the analyses was conducted using the Financial Analysis Tool for Electric Energy Projects financial analysis model (FATE2-P), described later in this appendix. The analysis for ground source heat pumps was conducted using the Federal Energy Decision System (FEDS) model, also described in this appendix.

\section{Analytic Approaches}

In assessing the economic feasibility of renewable energy projects at Yuma Proving Ground, PNNL generally evaluated two business case alternatives, (1) investment by an independent power producer (IPP), and (2) Energy Conservation Investment Project (ECIP) funding. These two funding sources have the best returns on Federal investments among the available alternatives. Two other alternatives were examined when conditions were also favorable, (3) the utility energy services contract (UESC), and (4) the energy saving performance contract (ESPC).

Under an IPP scenario, an independent power producer will generally fund, construct, and operate a renewable energy facility, selling power into the competitive marketplace and/or directly to the site that hosts the energy project. This scenario is generally economic when the third party investor can 
take advantage of substantial Federal and state incentives. The incentives depend on the type of renewable energy and may include production tax credits, investment tax credits, substantially accelerated tax depreciation of assets, reductions in sales taxes, and exemption from property tax.

The Energy Conservation Investment Program (ECIP) is one standard DoD approach for making energy efficiency and renewable energy investments using Federally appropriated funding. ECIP investment awards are made based upon savings to investment ratio (SIR) and simple payback (SPB) criteria. ECIP funding is limited, and is awarded on a competitive basis within the Army-only the most economic projects can be assured funding. The approach used in the analyses follows the federal life cycle cost methodology (LCC) and procedures in 10 CFR, Part 436, Subpart A. The LCC calculations are based on the Federal Energy Management Program (FEMP) discount rates and energy price escalation rates updated on April 1, 2008.

The utility energy services contract and the energy saving performance contract are very similar approaches, where a third party invests in an energy project on the Federal facility in return for a share of the energy savings that result. The major difference is that under an UESC, the third party is a utility_-generally the utility providing energy to the Federal facility. Under ESPC, the investment party is a non-utility, generally an engineering firm that specializes in energy projects. Under UESC and ESPC, the third party must be repaid out of each year's operational dollars, and the investment must be repaid within the lifetime of the asset. Generally, UESC is more feasible than ESPC because utilities can obtain capital less expensively than can the ESPC contractor. But not all utilities fund UESC projects and the types of projects funded may be limited, opening the door for ESPC. The UESC/ESPC cannot generally capture depreciation or tax incentives that would be afforded an independent power producer.

\section{Independent Power Producer Assumptions}

In addition to capital and operating costs, project feasibility for the independent power producer is dependent on Federal and State tax incentives, interest rates, inflation rates, and required rates of return discussed in the following sections.

\section{Federal Incentives for Renewable Energy}

Federal incentives for renewable energy include investment tax credits for corporations, significantly accelerated depreciation of equipment, and production tax credits. Combining the incentives with attractive market prices can, in certain cases, lead to feasible renewable energy projects.

\section{Tax Credits}

A 30\% business energy tax credit is available for photovoltaic projects and small-scale wind; geothermal and biomass electricity generation projects qualify for a 10\% investment tax credit (JCT 2007). Financial crisis emergency legislation lengthened the investment tax credit period by 8 years to January 1, 2017 from its previous end of December 31, 2008 (HR 1424). There are no incentive limits for solar and geothermal electric. Wind is NOT eligible for the business energy tax credit. The tax basis for depreciation must be reduced by the amount of any Federal subsidy used in the financing of the eligible equipment (26 USC $\S 48$ ). The basis of the facility is eligible for $50 \%$ of the total energy tax credit taken (JCT 2007). 


\section{Depreciation}

Most renewable energy equipment qualifies for significantly accelerated depreciation using the modified accelerated cost recovery system (MACRS). According to 168(e) (3) (B) (vi), most renewable energy production facilities would qualify for 5-year accelerated depreciation (US Treasury 2007).

Table A-1 provides the depreciation rates used in the model for 5-year property. The rates reflect the use of the 3/4-year convention. The basis is reduced by 50\% of any energy investment tax taken (JCT 2007).

Table A- 1: MACRS Depreciation Rates for Renewable Energy Projects

\begin{tabular}{|c|c|c|c|c|c|}
\hline Year 1 & Year 2 & Year 3 & Year 4 & Year 5 & Year 6 \\
\hline $35 \%$ & $26 \%$ & $15.6 \%$ & $11.01 \%$ & $11.01 \%$ & $1.38 \%$ \\
\hline
\end{tabular}

\section{Production Tax Credits}

The renewable energy production tax credit (PTC) provides a per-kWh-produced tax credit for electricity generated. The PTC is $2.1 \mathrm{k} / \mathrm{kWh}$ in 2007 for wind, geothermal, and closed-loop biomass (biomass that is grown with the sole purpose of being used to generate energy) and can be taken for 10 years. The PTC is $1.1 \mathrm{k} / \mathrm{kWh}$ for electricity produced from open-loop biomass and municipal solid waste resources and can be taken for 5 years. Solar electricity generation has been excluded for equipment placed in service after December 2005 (H.R. 6111 2006). The PTC has been allowed to lapse and then been renewed several times (DSIRE $2008 \mathrm{a}$ ). All of the analyses assume it will be available when the equipment is placed in service.

\section{Arizona specific incentives and taxes}

Arizona incentives are primarily in the form of avoided taxes. Arizona incentives include an investment tax credit for solar and wind; a reduction in property tax assessments for renewable energy production assets, except solar which is totally exempt; and an exemption from sales tax for solar and wind.

The Arizona investment tax credit for solar and wind is limited to $10 \%$ of the installed value and $\$ 25,000$ per building or a total $\$ 50,000$ per year for two buildings. The tax incentive is currently available through 2012. The property tax exemption applies only to solar, which is completely exempt from property tax. Other renewable energy resources such as wind, waste-to-energy and geothermal are only assessed at $20 \%$ of the depreciated value to which the property tax rate is then applied annually. For the purposes of this analysis, the property tax rate was assumed to be $1 \%$. Wind and solar energy production facilities are exempt from the sales tax during construction of the facilities. Local sales tax may be exempted for these resources as well, but as it is a local option, it was not reduced in our analysis (DSIRE 2008b).

Arizona has a renewable portfolio standard, which was adopted in 2006. The final rules require the $15 \%$ of electricity to be produced by renewable energy resources by 2025 . Of this total, $30 \%$ must come from distributed energy resources, one-half of which must be derived from residential, nonutility resources. Annual compliance requirements must be met. The requirements increase $1 \frac{1}{2} \%$ 
from 2\% in 2009 to 5\% in 2015 and 1\% per year thereafter until the 15\% requirement is met (DSIRE 2008b). The RPS stipulates that only utilities that are investor-owned are bound by the RPS. For Yuma Proving Ground, the RPS requirements are only applicable to APS. A RPS often creates a market for renewable energy certificates (RECs), which are also commonly known as green tags. RECs are the environmental attributes of electricity produced from renewable energy sources sold separately from the actual electricity. This is referred to as "unbundled." Consumers can buy RECs to support green power whether or not they have access to green power through their local utility and without having to switch electricity suppliers. Typically, marketers purchase RECs from renewable energy projects and sell them to consumers.

Utilities in Arizona must purchase bundled RECs to meet the requirements of their state's RPS. Bundling means that a utility cannot simply purchase unbundled RECs; it must participate in the renewable energy project. For example, TEP offers its production based incentive (PBI) to customers in exchange for the RECs they generate. Lastly, the purchased energy associated with the RECs must be deliverable to the Arizona grid. Moreover, the distributed generation REC is a specialized REC and is likely to be valued at a rate higher than that of the standard RECs the utilities must purchase. Consequently, several utilities, including APS, have put forth a request for proposals for distributed generation projects to help satisfy the RPS requirements. This has created several opportunities for local renewable energy project development which otherwise might not have of occurred. Yuma Proving Ground may be well positioned to potentially take advantage of such opportunities.

Because the RECs are bundled and not sold separately in Arizona, the market value is not publicly known, and the economic analysis calculations do not include the potential sale of RECs. Most transactions are two-party, confidential deals. But the sale of RECs could provide another revenue stream for renewable energy projects in addition to the price received (or cost avoided) for the actual electricity. If RECs could be sold, they would further increase the value of the energy produced.

The Arizona corporate tax rate is 6.968\% (AZDOR 2007). The sales tax for Yuma Proving Ground was assumed to be $7.6 \%$ (AZDOR 2008) for waste-to-energy and geothermal projects. We applied only local sales tax of $2 \%$ for solar and wind projects because it is a local option whether the sales tax is exempted. Property tax rates were assumed at $1 \%$.

\section{Other Independent Power Producer Assumptions}

The minimum after-tax internal rate of return used in the analysis of IPP opportunities was $10 \%$. The typical after-tax rate of return for most third party developers is closer to $15 \%$, but there appears to be a suite of renewable energy developers willing to accept a lower return. Both costs and prices were assumed to escalate with an inflation rate of $1.8 \%$. It should be noted that third party investors would probably need to negotiate backup power options with Yuma Proving Ground and WAPA, WMIDD,

and/or APS to assure that Yuma Proving Ground does not face substantial emergency power costs for any unplanned outages. 


\section{Energy Conservation Investment Projects}

The assumptions for ECIP are driven by the Federal Energy Management Program. Table A-2 lays out the discount rates underlying the model as of April 2008. The real and nominal rates for DOE/FEMP imply a 1.8\% inflation rate. New rates were obtained from Rushing and Lippiatt (2008).

Table A- 2: Discount Rate Assumptions in the ECIP Model

\begin{tabular}{|r|c|c|c|c|c|c||}
\hline Discount Rate & DOE FEMP & OMB 3-year & OMB 5-year & OMB 7-year & OMB 10-year & OMB 30-year \\
\hline real & $3.0 \%$ & $2.1 \%$ & $2.3 \%$ & $2.4 \%$ & $2.6 \%$ & $2.8 \%$ \\
\hline nominal & $4.9 \%$ & $3.9 \%$ & $4.1 \%$ & $4.2 \%$ & $4.4 \%$ & $4.7 \%$ \\
\hline
\end{tabular}

\section{FATE2-P Model Description}

The FATE2-P (Financial Analysis Tool for Electric Energy Projects) financial analysis model was used to evaluate the feasibility of renewable energy projects at Yuma Proving Ground. The spreadsheet model was developed by Princeton Economic Research, Inc. and the National Renewable Energy Laboratory for the U.S. Department of Energy. FATE2-P can be used to develop pro forma financial statements for a utility using a revenue requirements approach or an independent power producer using the discounted rate of return approach. Both approaches are diagrammed in Figure A-1. Other models produce very similar results given the same inputs. The revenue requirements approach follows a cost-based utility revenue requirements analysis, and the independent power producer approach uses a market-based discounted cash flow return. The FATE2-P model has been updated by PNNL to include the MILCON Energy Conservation Investment Program Module in addition to the rate of return methodology. The model has been used to model improved technology designs, resource variability, and favorable tax treatment on renewable energy products. The advantage this model over other models is that it is already suited for handling all of the renewable energy technologies in this study through one model, thus providing results on a comparable basis across all technologies. 

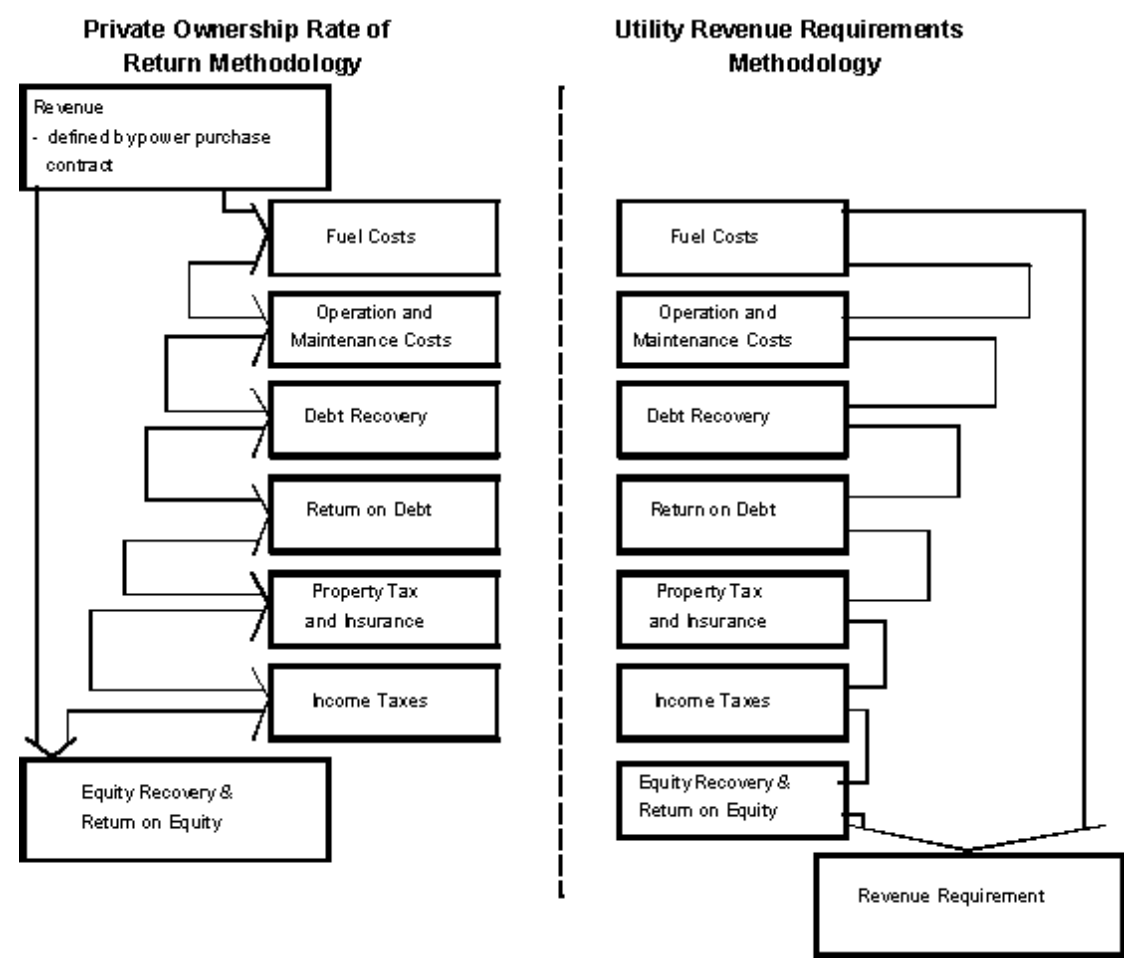

Figure A- 1: FATE2-P Methodology

\section{Private Ownership Rate of Return Methodology}

The private Ownership Rate of Return Module (independent power producer) develops an annual after-tax cash flow based on the revenues defined in the Power Purchase Contract and costs associated with constructing and operating the generation facility. The goal of this approach is to capture the relevant investment costs after-tax and compare them with the net cash flow from the investment after-tax over time. The model contains sections to capture the relevant costs of construction including the debt and equity capital accumulation to purchase the investment and the associated payback of debt and equity capital. In addition, the model has sections associated with revenue generation, cash flow, an income statement, and associated statements to calculate tax liabilities to capture after-tax cash flow. The financing section includes several pertinent sections including sources and uses, construction and debt accumulation, reserve funds requirements, debt schedule, amortization of debt fees, and debt service coverage ratios.

- The sources and uses of funds section shows the allocation of construction funds between components and sources of those funds. Uses of funds include construction cost, AFUDC (Allowances for funds used during construction), underwriters' fees for both debt and equity.

- The construction and debt accumulation statement is capable of handling a 6 year construction period starting at any date. Any construction draw schedule can be used for 1 to 6 years. An equal percentage draw schedule for each year of any given construction length is the default.

- The model contains major maintenance and debt-service reserve funds. Both types of accounts generate interest income that becomes a part of the income statement through a 
drawn-off interest calculation. The model does not currently calculate a working capital reserve account. Such an account would add interest costs to the cost statement in addition to the interest costs on the capital investment.

- The debt schedule allows three types of financing: level payment, bullet, and customized. Level payment is customary for projects that have adequate cash flow to satisfy debt coverage payments and are of short duration. Customized is required when certain years fall below the minimums set by the investment banking industry.

- Cash flow statements can be constructed for up to 30 years of revenue generation plus the 6 year construction period.

- The Revenue Module contains a variable capacity factor, which must be filled in by the analyst to capture depletion of the geothermal fields, the capacity of wind or of the other renewables' capacities. This section also allows for secondary energy by-product credits (such as for steam if it has value), and up to six different types of subsidy payments if available. The model also accepts after-tax production credits, if available, and includes any interest on reserves.

- Cash expenses statements include standard operations and maintenance costs (both fixed and variable), general and administrative expenses, insurance, and land fees. There is major maintenance expense along with a reserve fund dedicated to covering the major maintenance expense when it occurs. Up to two different fuel costs can be entered. There is also an entry for royalty fees associated with geothermal power.

- The earnings statement in this model calculates earnings and taxes based on a tax table. Operating income is calculated by subtracting cash and operating expenses from revenue as described in the section above. Taxable income is determined by subtracting cash and noncash expenses such as interest, depreciation, amortization of fees, IDC (interest during construction), and depletion allowances. Taxes paid and tax credits received are netted and after-tax book income is calculated. The net taxes paid become a part of the cash flow.

- The model includes straight-line and MACRS (modified accelerated cost recovery system) depreciation approaches, with mid-quarter convention deprecation tables. Straight-line allows for the calculation of book basis value of assets and liabilities, while MACRS allows for the taxable basis of the investment.

- The model amortizes debt related fees over 15 years and equity organizational fees over 5 years. Equity tax advice is expensed in the first year, and equity broker fees are excluded.

- The model calculates depletion allowances on geothermal power projects. The model also depletes certain AFUDC when appropriate.

- Income tax and other tax statements are prepared for Federal and State taxes paid as well as tax credits earned. Tax calculations include excise taxes, Federal, State and local taxes. Depreciation calculations used to capture after-tax cash flow can use either straight-line or 
MACRS. There is also section to incorporate local property taxes and special tax assessments.

- Assumptions: The assumptions section is fairly extensive and covers construction costs, debt acquisition, equity acquisition, capacity factors, fixed and variable O\&M inputs, financial factors such as interest rates, general and administrative expenses, real escalation in O\&M charges, unfired fuel assumptions, byproduct credits, asset life, inflation rates, tax rates, property tax rates, insurance, investment tax credits, AFUDC, local gross receipts tax, and special property tax assessments.

- Total plant cost (overnight) is divided into: sales tax; rotor, gearbox, generator; tower and civil work; controls, transformer, interconnect; design/Engineering; permitting/environmental, construction labor \& supervision; contingency; home office overhead; real escalation in construction cost; miscellaneous depreciable cost (last year of construction); sales tax on miscellaneous depreciable cost; land cost; and startup cost.

\section{ECIP Module}

The FATE2-P model includes a life cycle cost module based on the Buildings Life Cycle Cost (BLCC) model (produced by NIST) and a MILCON Energy Conservation Investment Program (ECIP) Module, which in turn fills out Form 1391. The ECIP module currently reflects 2008 forecast discount and inflation rates. The ECIP module provides first year savings, simple payback, total discounted operational savings, savings-to-investment ratio (SIR), and adjusted internal rate of return.

\section{The Federal Energy Decision System (FEDS) Model}

FEDS is a building energy modeling software developed by Pacific Northwest National Laboratory to support the economic analysis of efficiency technologies at large, multi-building sites. Building characteristics are entered into the model using as much detail as possible, and the model uses the given information to make inferences for the remaining characteristics. Multiple sets of building data can be entered into the same model, so that an entire site can be represented at once. The optimization cycle uses data about the location of the site and the energy prices entered into the model to determine cost-effective retrofits for each set of building data, and to calculate costs and savings. The suggested retrofits can range from lighting to building envelope to HVAC, covering all aspects of a building's energy use and considering interactive effects. In addition, the model can be adjusted to consider just one type of retrofit. In this renewable analysis conducted at Yuma Proving Ground, ground source heat pumps were the only technology analyzed. 


\section{Business Case Analysis References}

AZDOR-Arizona Department of Revenue. 2007. “Arizona Corporation Income Tax Return.” ADOR 91-0024 (07), Tucson, Arizona

AZDOR—Arizona Department of Revenue. August 2008. “Transaction Privilege (Sales) Tax Rate

Tables. http://www.revenue.state.az.us/TpT/tptrates/indextpt.asp Date accessed 10/14/2008.

DSIRE (a). 2008. Federal Incentive for Renewables and Efficiency: Business Energy Tax Credit. http://www.dsireusa.org/library/includes/incentive2.cfm?Incentive_Code

$=\mathrm{US} 02 \mathrm{~F} \&$ State=federal\&currentpageid=1\&ee=1\&re=1. Date visited 12/12/2008.

DSIRE 2008(b). “Arizona Incentives for Renewable Energy.”

http://www.dsireusa.org/library/includes/map2.cfm?CurrentPageID=1\&State=AZ\&RE=1\&EE=1. Date visited 8/1/2008. Last updated 5/2008.

H.R. 1424. October 2008. “Emergency Economic Stabilization Act of 2008. "Enrolled Bill.”

H.R.6111. December 2006. “Tax Relief and Health Care Act of 2006” (Enrolled as Agreed to or Passed by Both House and Senate). Section 207

Joint Committee on Taxation (JCT). October 4, 2007. "Description of the Chairman's Modification to the Provisions of the "Heartland, Habitat, Harvest and Horticulture Act of 2007," (JCX-96-07)

Rushing, Amy S., and Barbara C. Lippiatt. May 2008. "Energy Price Indices and Discount Factors for Life-Cycle Cost Analysis - April 2008: Annual Supplement to NIST Handbook 135 and NISTIR 853273-22 (Rev. 5/07). NBS Special Publication 709

United States Code. 26 USC § 48. Title 26. Internal Revenue Code. Subtitle A. Income Taxes. Chapter 1. Normal Taxes and Surtaxes. Subchapter A. Determination of Tax Liability. Part IV. Credits Against Tax. SubPart E. Rules for Computing Investment Credit.

U.S. Department of Treasury. “2007 Instructions for Form 4562: Depreciation and Amortization (Including Information on Listed Property.” Internal Revenue Service.

United States Code Service. 26 USC § 168 (2006). Title 26. Internal Revenue Code. Subtitle A. Income Taxes. Chapter 1. Normal Taxes and Surtaxes. Subchapter B. Computation of Taxable Income. Part VI. Itemized Deductions for Individuals and Corporations

United States Code Service. 16 USC § 796 (2006). Title 16. Conservation. Chapter 12—Federal Regulation and Development of Power. Subchapter 1. Regulation of the Development of Water Power and Resources. Definitions. 


\section{APPENDIX B}

\section{Analysis of Biomass and Waste-to-Energy Opportunities}




\section{Appendix B: Analysis of Biomass and Waste-to-Energy Opportunities}

\section{Biomass and Waste-to-Energy Technology}

The term "biomass" refers to renewable fuels used for power production that include agricultural waste, forest and wood processing waste, animal waste, industrial waste, dedicated biomass crops, and methane from landfills and wastewater treatment plants. Waste-to-energy (WTE) is similar, but includes municipal solid waste (MSW), construction, and demolition (C\&D) waste as fuel sources. These feedstocks qualify as renewable sources for Energy Policy Act of 1992 (EPAct) compliance purposes, but some states and alternative goals have different feedstock requirements. While biomass and WTE projects may be very different as to their sources, fuel collection modes, and fuel cost profiles, in the end, energy production often relies on similar technologies.

The primary technologies for producing electricity rely upon steam turbines, gas turbines, or combined cycle turbine generators. Generators are energized by steam produced from direct combustion of raw material, or a synthetic gas (syngas) produced through anaerobic digestion or gasification. Direct combustion and anaerobic digestion technologies are mature and have been proven commercially. Coal plants typically use combustion technologies, and biomass (typically wood) can be cofired with coal for a more simple renewable energy option. Gasification technologies are newer in the market, but are promising based on a number of successful installations. Anaerobic digestion is widely used but primarily for smaller applications in rural and municipal projects rather than large commercial installations.

The capital cost of biomass plants ranges from about $\$ 3,000$ to $\$ 10,000 / \mathrm{kW}$, depending upon scale and specific technologies used. Direct combustion technologies tend to be both larger and less capital intensive than those based on syngas. Digesters tend to have a higher unit cost, primarily because of their smaller size. Cofiring equipment is typically an order of magnitude less than a new combustion or gasification plant. Operation and maintenance (O\&M) costs for digesters are also more than with the other types, costing about $2.0 \$ / \mathrm{kWh}$, compared to about $1.0 \mathrm{q} / \mathrm{kWh}$ for combustion plants. There is little change in O\&M for cofiring, although there may be costs associated with preprocessing the wood waste. The advantage for digesters is the low cost of fuel, which is typically free local waste (i.e., sewage sludge, manure). Even a "free" feedstock such as crop wastes, which is not currently collected nor located at one site, does not guarantee a successful project, because collection, transportation, and storage costs can be, and often are, economically prohibitive. The economics of MSW projects are typically more attractive than other biomass projects because fuel is often delivered free or even accompanied by payment in the form of a tipping fee. Most landfills are operated or franchised by a local government. Many of these derive operating revenues from fees that are added to the actual operating costs of the landfill. As a result, the tipping fee may be inflated over actual costs and therefore not an accurate representation of costs that can be avoided.

Combustion (direct-fired) systems burn biomass to produce steam in a boiler, turning a turbine connected to a generator. This method of producing electricity is quite inefficient, at about 20 to $30 \%$. In direct-fired systems, combustion products tend to form deposits on the heat transfer surfaces, increasing maintenance requirements and decreasing the lifetime of these surfaces because of corrosion and erosion. Ash has to be collected and removed from the system. The variability of incoming feedstock in terms of its composition and moisture content can present problems in combustion systems, most notably with MSW and mixed feeds. Systems that use a more 
homogeneous feedstock benefit from more complete combustion, which increases efficiency and reduces combustion waste products and emissions. Various boiler designs try to address these issues.

Gasification is more efficient than combustion, but the technologies employed are not as mature or common in commercial operation. The two basic types of gasification are direct-fired (aerobic) and indirect-fired (anaerobic). Gasification uses oxygen (direct-fired systems only), steam, heat, and pressure to break down organic materials to produce syngas, which is primarily hydrogen and carbon monoxide. Syngas is cleaned to remove impurities, then is used to generate electricity in a gas turbine or fuel cell, or is used to produce transportation fuels and/or commercially valuable chemicals. The syngas resulting from direct-fired systems has a lower heating value than the syngas from indirect-fired systems, and requires significant upgrading and processing to be used as fuel. The inorganic materials are discharged as inert solids that can often be used for another purpose. There are many types of gasification designs that use different amounts of oxygen and steam at different stages and temperatures, producing different amounts of waste heat, syngas, and solids.

As mentioned, biomass can be added to replace a fraction of coal used in an existing combustion or gasification plant. This is a common practice with minimal capital cost involved, compared to standalone biomass or WTE systems. There is also less risk involved because the feedstock is mixed with a feedstock that has already been functioning well in an existing system, reducing the chances of clogging or other operational issues. However, a feedstock with similar properties to coal must be used; a consistently uniform size and heat content is important, so wood waste is typically the feedstock of choice.

Plasma melting is one gasification process just now entering the commercial market for use with MSW. Although it has a short track record, it is worth considering because of its positive attributes for use on a military facility. The plasma melter uses a plasma torch to decompose the material being gasified, resulting in a much higher temperature and more complete reaction. This new technology produces only syngas from the organics, molten metal from any metals, and a hard, glass-like substance from the other inorganics. Gaseous emissions are released and scrubbed to remove pollutants, and the solid waste can be sold and used for other commercial purposes, such as construction material. Ash collected from syngas cleaning can be fed back into the plasma melter. Hazardous materials can also be gasified in this process, sealing the toxic substances into the solid waste with no potential for leaching (EvTEC 2002).

Digesters tend to be smaller systems and are typically used exclusively for biomass. They are usually located at the biomass source, such as farms with significant amounts of animal manure and at wastewater treatment facilities. Digesters break down biomass in warm, wet environments to produce methane, which can be captured as fuel for generating electricity. Aerobic digesters are common in developing countries for production of heating and cooking fuel in rural areas. Anaerobic digesters limit the amount of oxygen in the gasification process, producing gas with a higher concentration of methane, which is better for power production. Because of the smaller size of digester systems, electricity is typically generated using fuel cells, microturbines, or reciprocating engines.

Methane is also produced through anaerobic digestion in landfills as the garbage underground breaks down. Traditionally, this methane has been left in the ground, but the risk of fire and greenhouse gas emissions has led the Environmental Protection Agency (EPA) to require landfills to remove the methane. The methane could be used in an electricity generation system if the economics are positive. The most economic opportunities for landfill methane capture and use are in cases where 
the landfill collects municipal solid waste (MSW), already has a collection system in place, is active or recently closed (methane production tapers off as landfills age), and has sufficient waste (typically at least 1 million tons) to generate a significant amount of methane. The landfill must be lined as well, to prevent water intrusion into the landfill that stifles digestion of the waste and methane production and to prevent the methane from migrating into the surrounding soil. New landfills are typically lined by regulation; many older ones are not. Methane production even from large landfills is relatively low; as a result, power facilities that use it are typically small systems located on-site using fuel cells, microturbines, or reciprocating engines.

For all of these technologies, except landfill gas, a power plant will require feedstock storage space, feedstock preparation equipment, feed equipment, processing equipment, product cleaning and collection equipment, electricity generation equipment, ash and waste storage space, water for steam and cooling, and emissions control equipment. The specific infrastructure and space required for each of these depends on the type of feedstock and process used, the amount of feedstock used, and existing site conditions. As an example, one plasma gasification project evaluated could process 250 tons of MSW per day in an 80-foot by 175 -foot area, not including storage space. However, permanent systems with infrastructure typically need up to 5 acres. Any existing electrical generation equipment may possibly be used as part of the new system, reducing site requirements, and thus requiring only space next to the existing system for the new equipment and connection lines.

Some feedstocks require year-round storage because they are only available seasonally (e.g., crop residue); some feedstocks are available almost continuously and require less storage space (e.g., MSW). In case of supply interruption, a plant will need to store enough material from a continuously available feedstock to provide fuel for about 20 days. This storage requirement could use about 40 acres of land, depending on the overall size of the plant. Some feedstocks can be compressed into uniform-sized pellets, which simplifies storage, transportation, and combustion. However, the pelletization process can increase fuel costs by up to $20 \%$. Storage areas may have to be located some distance away from the plant because of site constraints. However, nearby storage is preferred to reduce operational costs.

Emissions control requirements depend upon the process used and on regulations affecting the site. Some gasification processes (with gas scrubbers) produce no criteria pollutants, such as sulfur oxides $\left(\mathrm{SO}_{\mathrm{X}}\right)$ and nitrogen oxides $\left(\mathrm{NO}_{\mathrm{X}}\right)$. However, air emissions are inevitable if the resulting syngas is burned in a conventional power generator.

\section{Biomass and Waste-to-Energy Analysis Approach}

The critical factor in determining feasibility for biomass energy generation is feedstock availability. There are a number of potential feedstocks that were evaluated for use at Yuma Proving Ground. The following questions were asked about each feedstock:

- Does this material exist in the surrounding region within 60 miles? (30 to 60 miles is assumed to be the maximum economic transport distance.)

- How much is available within this area, on average? Is availability constant or variable, dependent on crop rotation cycles and/or other market conditions?

- How much is available for use as a feedstock? Availability is based on the feedstock being able to be collected and the lack of competing uses or markets. For example, wheat straw is 
typically left in the field to protect and rebuild the soil. If it is collected, the resulting bales may have higher value as animal bedding than as fuel, creating a competing market for what was otherwise a waste material on the ground.

- How much electricity can be produced from the available biomass? This is a function of the quantity of material available, moisture content, and its relative heat value.

In this analysis, if the capacity of a power plant using a given feedstock was less than $1 \mathrm{MW}$, it was not considered a feasible feedstock resource. The narrowed list of possible feedstocks was then evaluated on a simple economic basis. Feedstock costs were estimated based on tipping fees, collection costs, transportation costs, current market rates, and other relevant information. Other operational costs and construction costs were estimated by scaling existing plant data for the three primary technology types. Based on the amount of feedstock available and the size of plant required, a levelized cost of electricity was estimated for each.

For options that are reasonably close to being cost-effective, further economic analysis was completed, including evaluating tax credits and other incentives, different financing options, ranges of potential construction and operation costs, and ranges of feedstock costs and amounts. Risks or potential issues associated with these remaining options were noted to present all considerations surrounding an implementation decision. When possible, these were quantified. Additionally, because biomass or waste-to-energy projects typically provide baseload power, Yuma Proving Ground’s average electricity cost of 2.92\$/kWh was used for this economic analysis.

Biomass and landfill gas qualify as renewable energy sources under Arizona's Renewable Portfolio Standard (RPS). The RPS includes a distributed generation clause, which may create a market for renewable energy certificates (RECs) and result in additional funding for projects that utilize these feedstocks. This possibility was taken into account for the biomass and landfill gas analysis. MSW does not qualify as a renewable energy source and thus the potential for RECs does not apply. However, the RPS does not cover WMIDD or WAPA, the utility that provides the vast majority of Yuma Proving Ground's electricity, and the quantity of energy provided by APS is small and beyond the range of typical waste-to-energy and biomass plant range. Therefore, unless conditions change, it is unlikely that RECs could be sold for a biomass or waste-to-energy project at Yuma Proving Ground.

PNNL staff created a new tool that supports analyses of various plant sizes, costs, and fuel sources in a generic manner. This facilitates "what if" analyses where critical information about fuel source and cost is unavailable. The result is an estimate of what power from a project would cost using available data and staff assessments for missing data. It also allows staff to reverse engineer an answer given Yuma Proving Ground's energy cost. Specifically, the tool can be set up to provide an estimate of what size plant and fuel cost is needed to produce power for less than the current and projected future power rate. Data from a 2003 National Renewable Energy Laboratory (NREL) study of biomass fuels was used to initiate the analytic tool. The 2003 study costs were converted into 2007 dollars and scaled according to varying plant sizes following the methodology used in the study. Any size plant can be evaluated, and any value can be varied to test for financial feasibility. The tool was only used for preliminary screening, because it does not adequately address taxes, incentives, or other factors. These economic factors have a significant impact on project feasibility, especially if the power project is not owned and operated by the government. 
This analytic approach was used to evaluate all biomass options, without making preliminary assumptions about feedstocks or technologies. In other words, it was used to develop preliminary estimates of electric generation costs using a "What if feedstock X were available?" The results of this preliminary analysis are useful for framing a biomass or WTE strategy. If the analysis resulted in estimated costs that are highly uneconomic, the option was rejected.

Lastly, Yuma Proving Ground is located near several other military installations including Luke AFB and the Yuma Marine Corps AS. Although this analysis is beyond the scope of this study, Yuma Proving Ground could also consider combining the waste resources of these closely located facilities to increase the potential waste resource, which would allow for larger and more economic waste-toenergy projects.

\section{Biomass and Waste Resource Characterization}

The following biomass and waste types were assessed for potential as feedstocks.

- Agricultural (crop residues, animal waste, dedicated biomass crops)

- Forest (thinnings, logging slash)

- Industrial (mill residue, other industry waste)

- Waste (MSW, C\&D waste, landfill gas, biogas or biosolids from wastewater treatment plants)

\section{Agricultural Biomass}

The USDA has a database of agricultural production information by county and state. Information about corn, wheat, other crops/orchards/vineyards, and poultry, pig, and cow production was collected from this source.

\section{Crop Residue}

Crop residues are the plant remains in the field after harvest. Some crops have more residues than others; some, like hay, have no residues at all because the entire plant is harvested. A certain amount of residue left on the soil minimizes erosion and maintains soil nutrients. However, too much residue can inhibit growth of a new crop. Depending on tilling practices, climate, crop type, soil type, and slope of the land, residue may or may not be available for removal. In general, conventional till practices need more residue than no-till practices; warm wet climates need more residue than cold dry climates; corn fields need more residue than wheat fields; coarse, well-drained soils need more residue than poorly-drained, heavy clay soils; and steeper slopes need more residue than flat land. In addition, crop residue availability is dependent on competing uses, like cattle feed, and seasonal yields, which can change dramatically from year to year.

In 2007 and 2008 in counties within 60 miles of Yuma Proving Ground, the major crops harvested that left residues were wheat, barley, sorghum, and cotton. See Table B-1 for the average number of bushels and amount of residue produced over 2007 and 2008. Available residue for biomass energy generation will be somewhere between these values and zero. A rule of thumb is that about $30 \%$ of the residues can be collected. However, these numbers will have to be verified on a farm-by-farm basis for a more accurate analysis. 
Table B- 1: Crops and Biomass Production near Yuma Proving Ground

\begin{tabular}{|l|c|c|c|c||}
\hline \hline & $\begin{array}{c}\text { Bushels } \\
\text { Produced }\end{array}$ & $\begin{array}{c}\text { Tons Residue } \\
\text { Remaining }\end{array}$ & $\begin{array}{c}\text { Tons Collectable } \\
\text { Residue }\end{array}$ & $\begin{array}{c}\text { Potential Electricity } \\
\text { Generation }\end{array}$ \\
\hline Wheat & $5,989,100$ & 233,753 & 70,126 & $8.4 \mathrm{MW}$ \\
\hline Barley & 169,350 & 4,234 & 1,270 & $0.2 \mathrm{MW}$ \\
\hline Sorghum & 259,600 & 6,490 & 1,947 & $0.2 \mathrm{MW}$ \\
\hline Cotton & 74,650 (bales) & 7,465 & 6,719 & $0.8 \mathrm{MW}$ \\
\hline Total & $\mathbf{6 , 4 9 2 , 7 0 0}$ & $\mathbf{2 5 1 , 9 4 2}$ & $\mathbf{8 0 , 0 6 2}$ & $\mathbf{9 . 6}$ MW \\
\hline
\end{tabular}

It would cost about $\$ 10 /$ ton to transport the residues to the biomass plant, and about $\$ 10 /$ ton for the farmer's collection effort. Therefore, the crop residue feedstock cost is about \$20/ton. Using all crops together to gain the largest benefit from economies of scale, the most cost-effective biomass option would be combustion, producing 7.1 MW of electricity at $12.4 \$ / \mathrm{kWh}$. This is more expensive than Yuma Proving Ground's electric rate, and is not an economic option at this time. Furthermore, Yuma Proving Ground's average demand is about $5 \mathrm{MW}$, so a 7.1 MW plant could require involvement with local utilities to find a use for the supplemental generated electricity. A $5 \mathrm{MW}$ combustion plant would produce electricity at $13.1 \mathrm{\$} / \mathrm{kWh}$, which is not cost-effective compared with Yuma Proving Ground's current electric rate. However, because biomass qualifies under Arizona's RPS as a renewable energy source, if general or distributed generation RECs can be secured, the economic potential of a biomass project could increase. An additional $10.2 \$ / \mathrm{kWh}$ would be required from RECs to result in a cost-effective project.

Residue availability is dependent on competing uses, including cattle feed, which can pay almost $\$ 42 /$ ton for corn stover and over $\$ 21 /$ ton for wheat straw. The crops also compete against each other based on market demand and, because each crop yields different amounts of residue, the amount of feedstock available will vary. Availability is also dependent on seasonal yields, which can change dramatically.

Sufficient on-site storage of the residue is important to avoid incurring further costs for storage elsewhere. A significant amount of space is required to store crop residue, because it is only available twice a year, after harvest.

In conclusion, crop wastes are potentially available for use as biomass feedstock; however, the value from the electricity generated from these wastes is not competitive with commercial rates unless RECs are pursued. In addition, annual crop yield varies because of crop rotation, market conditions, and weather patterns such that the volume of crop-specific feedstock is highly variable. This increases the risk that sufficient fuel will not be available on an annual basis. Finally, there are alternative markets for the crop residue that provide intervening opportunities in terms of market access (alternative markets are closer to the source) and market price. Therefore, it is not recommended to pursue wheat, barley, sorghum, or cotton residues for electricity production.

\section{Animal Waste}

Manure from cattle, swine, and poultry farms is generally reclaimed from animal housing and feeding areas and used as fertilizer for crops. This has become a problem because of overapplication. Bad odors and groundwater contamination are forcing farmers to find other ways to dispose of manure. Furthermore, greenhouse gas emissions are now more strictly regulated, so emissions from manure must be controlled. Anaerobic digestion technologies can turn wet manure into energy, and often can be used with existing collection and treatment systems. Poultry waste can 
be used directly in combustion or gasification systems because it has a lower moisture content than cow or swine manure.

In 2008, there were 118,000 cattle on feedlots within 60 miles of Yuma Proving Ground, none of which were on-site. There were no known swine or poultry farms in the area. All of the cattle may be kept in pastures instead of feedlots, but at a minimum, beef cattle can be assumed to stay in pastures. Manure in pastures is not good feedstock material because it is not typically collected (increasing the costs and decreasing in volume as it dries in the field). Only the manure from cattle on a feedlot can be assumed to be available for electricity generation. This number would have to be verified on a farm-by-farm basis for accuracy.

If all of the cattle were assumed to be on feedlots, the manure could generate $14 \mathrm{MW}$ of power. However, using manure to generate energy at any distance from the source will not be cost-effective. Cow manure is only $12 \%$ solids as excreted, and then is typically collected with a flush system, watering it down even further. On a dry basis, manure has an energy content of about 17 MMBtu/ton, and is transportable; but wet manure has an energy content of about $2 \mathrm{MMBtu} / \mathrm{ton}$ or less. Drying the manure on-site would incur costs to the farm, and then the manure would have to be sold at a profit by the farmer. These costs would be in addition to transportation costs, which would typically be about $\$ 10 /$ ton. Transporting wet manure would increase costs (as a result of increased volume and hence increased number of trucks) beyond what is economically feasible. Because of the expenses of liquid removal, transportation, and anaerobic digestion equipment, using manure for energy generation at Yuma Proving Ground is not feasible.

\section{Dedicated Crops}

Dedicated energy crops include switchgrass, hybrid poplar, willow coppice, and other SRWC (short rotation woody crops). Jatropha and eucalyptus are more recently being considered as biomass crops. Energy crops are fast-growing plants that can be harvested for use as energy in various forms. Switchgrass is a native prairie grass that grows best in warm dry climates like the Midwest. SRWC need a lot of water and do well in colder climates like the Northeast. They need at least 16 inches of rainfall per year, or need to be located on a body of water. Using dedicated crops as biomass is an option, but they are not a readily available resource. Rather, agricultural land where the crops can be grown is the resource to be evaluated, and the feedstock cost would be based on the cost to farm that land, harvest the resource, and deliver it to the generation plant on post.

None of the traditional energy crops are suited to the region near Yuma Proving Ground. The soil and climate do not naturally favor crop growth, and irrigation or other extensive agricultural practices are cost-prohibitive. Eucalyptus, however, is said to grow well in this region. The cost to grow and harvest eucalyptus can range from \$35 to \$54 per ton, depending on planting density and length of rotation. At this cost, a plant that will meet all of Yuma Proving Ground's average energy demand (5 MW) will produce electricity at a cost of over $15 \$ / \mathrm{kWh}$, which is not an economic option.

Jatropha would also be difficult to use economically. It is an unproven resource regarding its cultivation and use with biomass technologies, and is primarily known to produce an oil that can be used for biofuels, rather than serve as plant matter for biomass. Assuming jatropha was available as a reliable biomass resource at a cost of $\$ 10 /$ ton (a conservative estimate for growing and harvesting a crop); a $5 \mathrm{MW}$ jatropha plant would generate electricity at over $14 \mathbb{\$} / \mathrm{kWh}$. Because this is an unproven resource and the economics are marginal, it is not recommended to pursue jatropha. 
Although dedicated energy crops are not a feasible biomass option under current electricity rates, if RECs are pursued as an additional funding source, utilizing energy crops as a feedstock could result in a cost-effective project.

\section{Forest Biomass}

Forest Thinnings and Logging Slash

Logging slash includes branches, stumps, and other material that is generated during logging practices but left behind because it is not useful to the loggers seeking large tree trunks. Once this slash is cut and left on the forest floor, it dries out, becoming good fuel for fires. It also can hamper the machinery used during replanting efforts. Sometimes it is gathered into small piles and burned in a controlled manner to reduce the risk of widespread forest fire, but this practice pollutes the air and may be restricted by air quality regulations. Instead, it can be collected and transported to a biomass facility where the emissions can be controlled and the wood waste can be used to generate energy.

There are no forested areas near Yuma Proving Ground. Thus, forest thinnings and slash are not available for use as biomass to generate electricity.

\section{Industrial Biomass}

Industrial biomass includes mill residue, food processing waste, textile waste, or waste from other specialized operations.

\section{Mill Residue}

There are many types of mills that use wood to produce various products, including lumber, shake and shingle, pulp, veneer and plywood, log chips, and posts, poles, and pilings. These processes generate waste in the form of sawdust and wood pieces, which are useful materials. In fact, most mill residue is currently used for fiber, fuel, or other uses.

There are no mills in the Yuma Proving Ground region because there is no forestry industry. Therefore, mill residue is not a feasible resource.

\section{Other Residue}

There are no large industrial facilities in the Yuma Proving Ground area that generate waste usable for biomass.

\section{Waste Biomass}

\section{Municipal Solid and Urban Wood Waste}

MSW and C\&D waste are being generated at greater rates each year while landfills are filling up, resulting in greater hauling distances and increasing prices for waste disposal. Recycling is one way to reduce the strain on landfills; using the waste to generate energy is another. Some recyclables, like metals, must be separated out before the waste is used for energy generation. All carbon-based materials, however, can be used to generate energy.

There is one active landfill at Yuma Proving Ground. Because specific information (including tipping fees and type and tonnage of waste collected per year) about this landfill is unknown, on-site waste was not included in this assessment. Considering the population at Yuma Proving Ground, it is unlikely that on-site waste will greatly affect the feasibility of a biomass project. Within 60 miles of Yuma Proving Ground, there are two operating landfills, one in Yuma, and one in Wellton. Waste 
disposed in this area totals about 239,000 tons per year, and is expected to remain about the same as a result of increasing populations balanced by new recycling programs. These landfills and the closest transfer stations are summarized, with their respective tipping fees, in Table B-2.

Table B- 2: Waste near Yuma Proving Ground

\begin{tabular}{||l|c|c|c|c|c|c||}
\hline \multicolumn{1}{|c|}{ Site } & $\begin{array}{c}\text { Collection } \\
\text { Location }\end{array}$ & $\begin{array}{c}\text { Miles from } \\
\text { Yuma Proving } \\
\text { Ground }\end{array}$ & $\begin{array}{c}\text { Tipping } \\
\text { Fee (\$) }\end{array}$ & $\begin{array}{c}\text { Assumed } \\
\text { Cost } \\
\text { Savings (\$) }\end{array}$ & $\begin{array}{c}\text { Available } \\
\text { MSW } \\
\text { (tons/year) }\end{array}$ & $\begin{array}{c}\text { Potential } \\
\text { Electricity } \\
\text { Generation } \\
\text { (MW) }\end{array}$ \\
\hline \hline $\begin{array}{l}\text { Yuma Proving } \\
\text { Ground }\end{array}$ & $\begin{array}{c}\text { Yuma } \\
\text { Proving } \\
\text { Ground }\end{array}$ & 0 & N/A & N/A & N/A & N/A \\
\hline $\begin{array}{l}\text { South Yuma } \\
\text { Landfill }\end{array}$ & Yuma & 30 & $\$ 25$ & $\$ 12.50$ & 46,264 & 5 \\
\hline $\begin{array}{l}\text { Copper Mountain } \\
\text { Landfill }\end{array}$ & Wellton & 30 & $\$ 30.25$ & $\$ 15.12$ & 192,721 & 21 \\
\hline \multicolumn{1}{|r|}{} & & TOTAL & $\mathbf{2 3 8 , 9 8 5}$ & $\mathbf{2 6}$ \\
\hline
\end{tabular}

The assumed cost savings for each site is discounted 50\% from the tipping fee, to account for any additional transportation needs and incentives to deliver waste to a new location.

Each landfill's waste could be an option for use as feedstock, either separately or in combination with other sources. Depending on contracts, plans, capacity needs, and economic issues at each landfill none or all waste may actually be available. Therefore, other options may need to be considered, including combinations of partial waste from more than one location.

The technologies considered for waste conversion include combustion, gasification, and plasma melting. Combustion releases more emissions than the other options, but the other technologies are newer to the market, especially for use with MSW. See the Findings section below for the economic analysis of using MSW for electricity generation.

\section{Landfill Gas}

Methane generated from decomposing waste is a combustible pollutant that must be controlled. It is typically vented or collected and flared to avoid buildup and danger of explosion. New greenhouse gas regulations are expected to require collection of landfill methane. Collected methane can be used as a fuel to generate heat or electricity.

Landfill gas is typically piped economically no more than 2 to 5 miles, although it has been piped up to 20 miles away. The on-site landfill at Yuma Proving Ground is the only landfill close enough for possible landfill gas utilization, because the other two landfills are both 30 miles from Yuma Proving Ground.

For a worthwhile landfill gas project, the landfill must have at least 1 million tons in place, be at least 30 feet deep, receive at least 25 inches of rain annually, and be lined. Because Yuma receives only about 3 inches of precipitation per year, utilizing landfill gas as a source of renewable energy is not feasible. 
Executive Order 13514 was recently signed into law that requires Federal facilities to report and reduce their greenhouse gas emissions by $20 \%$ by 2020, relative to a Fiscal Year 2008 baseline. As a result, more incentives could arise in the future that could make a landfill gas project more economic. However, because of the relatively small size of the Yuma Proving Ground landfill, it is likely that other, more cost-effective measures exist to achieve the greenhouse gas reduction requirements (such as waste reduction through increased recycling or composting). Furthermore, if the emissions from the landfill comprise a small percentage of the overall site emissions, it may be more beneficial for the site to focus greenhouse gas reduction efforts on other sources of emissions.

\section{Wastewater Treatment Plant (WWTP) Sludge}

WWTP sludge is what remains after wastewater is treated and the clean water is returned to the ground or other body of water. It has a high-energy content when dried, but the drying process is energy-intensive and necessary before transportation. Sludge is similar in substance to manure; it is a very watered-down substance that is best processed on-site, where methane is generated with anaerobic digestion. Therefore, only on-site sources of sludge are reasonable to use for energy generation.

There is a wastewater treatment plant on-site at Yuma Proving Ground. However, no data regarding the annual volume of wastewater processed or sludge produced was available prior to completing this analysis. According to the Water Environment Research Foundation (WERF), to produce $100 \mathrm{~kW}$ of electricity, an influent flow rate of 4.5 million gallons per day (MGD) is required. A flow rate of 45 MGD would then be necessary to generate $1 \mathrm{MW}$ of electricity. Given the population of Yuma Proving Ground and the surrounding area, it is very unlikely that the on-site WWTP meets this flow rate requirement. Therefore, WWTP sludge is not a feasible resource.

\section{Biomass and Waste-to-Energy: Economic and Other Analysis Parameters}

Data used in this analysis were obtained from local sources when possible, and the economic assumptions were generally conservative. Our assumptions are presented in the report. However, any significant changes to important assumptions may change outcomes-opportunities that are just barely economic in this report may no longer be economic if the values are changed significantly.

Biomass and WTE options were analyzed using Energy Conservation Investment Program (ECIP) and independent power producer (IPP) funding scenarios. Cost-effectiveness for ECIP projects is determined with savings-to-investment ratio (SIR) values, and the internal rate of return (IRR) shows whether the IPP scenario is cost-effective. The economic assumptions used to analyze each scenario, including available incentives, are listed in Table B-3. The assumptions that vary per scenario are listed below with the results. The average cost of electricity that Yuma Proving Ground would pay for the renewable energy was assumed to be $2.92 \$ / \mathrm{kWh}$. 
Table B- 3: Economic Assumptions, constant \$2007

\begin{tabular}{|c|c|}
\hline \multicolumn{2}{|l|}{ Economic Factors } \\
\hline Inflation & $1.8 \%$ \\
\hline Interest Rate & $10.0 \%$ \\
\hline Debt/Equity Ratio & N/A \\
\hline Real Discount Rate & $3.0 \%$ \\
\hline \multicolumn{2}{|l|}{ Tax Considerations } \\
\hline Federal Depreciation & MACRS \\
\hline Federal Tax Rate & $35 \%$ \\
\hline State Income Tax Rate & $7.0 \%$ \\
\hline State Sales Tax & $7.6 \%$ \\
\hline Property Tax Rate & $1.0 \%$ \\
\hline \multicolumn{2}{|l|}{ Incentives } \\
\hline Federal Production Tax Credit & $\$ 0.01 / \mathrm{kWh}$ \\
\hline State Production Tax Credit & $\$ 0.00 / \mathrm{kWh}$ \\
\hline Federal Energy Tax Credit & $0 \%$ \\
\hline State Energy Tax Credit & $0 \%$ \\
\hline Utility Rebate & $\$ 0 / \mathrm{kW}$ \\
\hline \multicolumn{2}{|l|}{ Technology } \\
\hline Plant Life & 30 years \\
\hline $\begin{array}{l}\text { Capacity Factor (basis net kW } \\
\text { output): Total System }\end{array}$ & $85 \%$ \\
\hline Real Escalation in Construction Cost & $0 \%$ \\
\hline $\begin{array}{l}\text { Misc. Depreciable Cost (last year of } \\
\text { construction) }\end{array}$ & $\$ 0$ \\
\hline $\begin{array}{l}\text { Sales Tax on Misc. Depreciation } \\
\text { Cost }\end{array}$ & $\$ 0$ \\
\hline Land Cost & $\$ 0 / \mathrm{kW}$ \\
\hline Startup Cost & $\$ 0 / \mathrm{kW}$ \\
\hline
\end{tabular}

\section{Findings: Biomass and Waste-to-Energy Opportunities}

There do not appear to be any feasible biomass-to-electricity projects on post greater than $1 \mathrm{MW}$. The availability of dedicated biomass crops, forest thinnings and logging slash, mill residue, other industrial waste, landfill gas, and WWTP sludge are all inadequate for a large biomass generation project. Other potentially available biomass fuels, including crop residue and animal waste, could not support economic electricity generation. Waste-to-energy using MSW is the best option for generating a more significant amount of electricity at Yuma Proving Ground. Project economics will depend on the availability and price of waste, and actual plant size, capital costs, and operating costs. 
As previously mentioned, all waste in the area was evaluated for economic feasibility as either a combustion, gasification, or plasma melting WTE project. The most cost-effective options are presented in Table B-4. Projects utilizing only waste from South Yuma Landfill showed highly unfavorable economics and thus were excluded from the results.

Table B- 4: MSW Waste-to-Energy Results

\begin{tabular}{|c|c|c|}
\hline Waste Source(s) & $\begin{array}{l}\text { Copper } \\
\text { Mountain } \\
\text { Landfill }\end{array}$ & All Waste \\
\hline Technology & Combustion & Combustion \\
\hline Plant Size & $21.2 \mathrm{MW}$ & $26.3 \mathrm{MW}$ \\
\hline Feedstock Amount & $\begin{array}{c}192,721 \\
\text { tons/yr }\end{array}$ & $\begin{array}{c}\text { 238,985 } \\
\text { tons/yr }\end{array}$ \\
\hline Total Plant Cost & $\$ 3,256.5 / \mathrm{kW}$ & $\$ 3,119.4 / \mathrm{kW}$ \\
\hline Capital Cost & $\$ 3,026.5 / \mathrm{kW}$ & $\$ 2,899.1 / \mathrm{kW}$ \\
\hline Sales Tax & $\$ 230.0 / \mathrm{kW}$ & $\$ 220.3 / \mathrm{kW}$ \\
\hline Fixed O\&M Cost & $\$ 96.3 / \mathrm{kW}$ & $\$ 92.3 / \mathrm{kW}$ \\
\hline Variable O\&M Cost & $-0.6 \mathrm{c} / \mathrm{kWh}$ & $-0.6 \nsubseteq / \mathrm{kWh}$ \\
\hline Feedstock Cost & $-\$ 15.13 /$ ton & $-\$ 14.62 /$ ton \\
\hline SIR & 0.6 & 0.6 \\
\hline Simple Payback & 20.6 years & 19.8 years \\
\hline $\begin{array}{l}\text { Internal Rate of } \\
\text { Return (IRR), No } \\
\text { Financing }\end{array}$ & $3.88 \%$ & $4.30 \%$ \\
\hline
\end{tabular}

These scenarios show that the most cost-effective option, using all waste in a combustion plant, gives a simple payback of 19.8 years. This analysis was completed assuming that all waste collected or processed at these facilities will be available, and assumptions were made about feedstock costs and available revenue from avoided tipping fees. These assumed amounts of waste or revenue may or may not be available, possibly resulting in more or less attractive options.

The size of this combustion plant, 26 MW, is over three times the average demand at Yuma Proving Ground, which would require involvement with local utilities to find a use for the supplemental generated electricity. Arizona is a deregulated state and selling electricity to local utilities is theoretically possible, but conversations with utility representatives indicated that net metering might be challenging in the area around Yuma Proving Ground. Given the unattractive economics, feedstock assumptions, and excessive size of this project, it is unlikely that a waste-to-energy plant would result in a cost-effective project. Thus, it is not recommended to pursue a waste-to-energy project at this time. 


\section{Biomass and Waste-to-Energy: Next steps}

Because no source of biomass or waste resulted in a cost-effective project, it is not recommended to pursue any biomass or waste-to-energy options at this time. Because of the climate and relative remoteness of the area surrounding Yuma Proving Ground, it is unlikely that feedstock amounts will increase significantly enough in the near future to make a biomass or waste-to-energy project economically feasible. However, it is possible that with rising costs of electricity and/or tipping fees, the economics of a waste-to-energy project could become more attractive and thus a feasible option for Yuma Proving Ground. Furthermore, a biomass project could become cost-effective if RECs are pursued. In such cases, assumptions regarding the amount of available feedstock, equipment capacities, and local cost data for equipment, feedstock, O\&M, and generated electricity would need to be checked. A site would need to be selected, and a developer secured before design and final economic calculations could be completed.

\section{Biomass and Waste-to-Energy Sources of Information}

Aabakken, J. “Power Technologies Energy Data Book.” National Renewable Energy Laboratory. Fourth Edition. NREL/TP-620-39728. Golden, CO, August 2006.

Arizona Department of Environmental Quality. "Recycling Program Report.” A.R.S. §49-832.C. FY 2002. http://www.azdeq.gov/function/forms/download/2002/recycle.pdf.

Arizona Metro. “Facts about Yuma”. http://www.azmetro.com/yumafacts.html

Bain, RL, WA Amos, M Downing, RL Perlack. "Biopower Technical Assessment: State of the Industry and Technology.” Golden CO, National Renewable Energy Laboratory. NREL/TP-510-33123. March 2003.

Burke, Dennis. "Dairy Waste Anaerobic Digestion Handbook.” Encyclopedia of Animal Science. Environmental Energy Company. June 2001. http://www.makingenergy.com/Dairy\%20Waste\%20Handbook.pdf.

De La Torre Ugarte, DG, ME Walsh, H Shapouri, SP Slinsky. "The Economic Impacts of Bioenergy Crop Production on U.S. Agriculture.” Knoxville, TN, University of Tennessee Agricultural Policy Analysis Center. July 2000.

Energy Information Administration. "Average Heat Content of Selected Biomass Fuels." http://www.eia.doe.gov/cneaf/solar.renewables/page/trends/table10.html. Accessed September 2007.

Environmental Protection Agency Landfill Methane Outreach Program. http://www.epa.gov/lmop/proj/index.htm. Accessed October 2007.

Gallagher, Paul, et al. "Biomass from Crop Residues: Cost and Supply Estimates.” United States Department of Agriculture, Office of the Chief Economist. February 2003.

http://www.usda.gov/oce/reports/energy/AER819.pdf.

Haq, Zia. “Biomass for Electricity Generation.” Energy Information Administration. July 2002. http://www.epa.gov/solar/pdf/haq_apr20.pdf.

IEA Energy Technology Essentials. "Biomass for Power Generation and CHP." http://www.iea.org/textbase/techno/essentials3.pdf. January 2007. 
Lamar, David, Integrated Environmental Technologies, LLC. Personal communications. October 2007. McDaniel, Edward, Engineer. ES Alternatives. Personal communications. April 2008.

Research Reports International. “The Use of Biomass for Power Generation in the U.S.” Evergreen, CO, July 2007.

Smith, Carl Benjamin, et al. "Lesser Known Energy Sources: A Study of Biogas and Tire Based Fuel.” Lockheed Martin. September 2007.

http://www.aeecenter.org/DivisionNewsletters/AREDI/Fall07/biogas-tires.pdf.

Soil Quality National Technology Development Team. “Crop Residue Removal for Biomass Energy Production: Effects on Soils and Recommendations.” National Resources Conservation Service. http://soils.usda.gov/sqi/management/files/sq_atn_19.pdf. August 2006.

Stone, Robert, et al. "Universal Soil Loss Equation (USLE).” Ministry of Agriculture, Food and Rural Affairs. http://www.omafra.gov.on.ca/english/engineer/facts/00-001.htm\#tab2. May 2000.

The Landfill Site. “Landfill Liner Leaks.” http://www.landfill-site.com/html/landfill_liner_leaks.html. Accessed October 2008.

United States Department of Agriculture Forest Service. "Forest Inventory \& Analysis Mapmaker Program on Timber Products Output Studies.” http://www.fia.fs.fed.us/program-features/tpo/. Accessed April 2008.

United States Department of Agriculture National Agricultural Statistics Service. http://www.nass.usda.gov/Data_and_Statistics/Quick_Stats/. Accessed April 2008.

United States Environmental Protection Agency. Turning a Liability into an Asset: A Landfill Gas-toEnergy Project Development Handbook. Landfill Methane Outreach Program. Washington DC, September 1996.

Water Environment Research Foundation. "Fact Sheet. Wastewater Sludge: A New Resource for Alternative Energy and Resource Recovery.” May 2008.

http://www.werf.org/AM/TemplateRedirect.cfm?template=/CM/ContentDisplay.cfm\&ContentID=9898

Water Environment Research Foundation. "State of Science Report: Energy and Resource Recovery from Sludge Executive Summary.” May 2008.

http://www.werf.org/AM/CustomSource/Downloads/uGetExecutiveSummary.cfm?FILE=ESOWSO3R07.pdf\&ContentFileID=7538

Walsh, Marie E., et al. "Biomass Feedstock Availability in the United States: 1999 State Level Analysis.” Oak Ridge National Laboratory. January 2000.

http://bioenergy.ornl.gov/resourcedata/index.html. 


\section{APPENDIX C}

\section{Analysis of Geothermal Plant Opportunities}




\section{Appendix C: Analysis of Geothermal Power Plant Opportunities}

\section{Geothermal Power Plant Technology}

Geothermal power plants use steam from hot water reservoirs found deep below the Earth's surface. The steam rotates a turbine that activates a generator, producing electricity. There are three commercial types of geothermal power plants used to generate electricity (dry steam, flash steam, and binary cycle), and several newer technologies are entering the marketplace (hot dry rock and engineered geothermal systems). The type of plant depends on the state of the fluid (whether it is steam, hot water, or mixed) and its temperature.

- Dry Steam power plants use underground steam piped directly from wells to the power plant, where it passes through separators to remove small particles before it is directed into a turbine/generator unit. There are only two known underground resources of steam in the United States: The Geysers in northern California and Yellowstone National Park in Wyoming. The only dry steam plants in the country are at The Geysers.

- Flash Steam power plants use geothermal resources that produce high-temperature hot water or a combination of steam and hot water. This very hot water (reservoirs greater than $360^{\circ} \mathrm{F}$ or $182^{\circ} \mathrm{C}$ ) flows up through wells in the ground under its own pressure. As it flows upward and the pressure decreases, some of the hot water boils (flashes) into steam. The steam is then separated from the water and used to power a turbine/generator. Any leftover water and condensed steam are injected back into the reservoir, making this a sustainable resource. Depending on the temperature resource, it may be possible to use a second flash tank, where more steam at a lower pressure is separated for generation (double flash plant).

- Binary Cycle power plants utilize a second fluid in a closed cycle to operate the turbine, instead of direct geothermal steam. These plants operate on water at lower temperatures of about $225^{\circ}-360^{\circ} \mathrm{F}\left(107^{\circ}-182^{\circ} \mathrm{C}\right)$. The heat from the hot water is used to boil a working fluid, usually an organic compound with a low boiling point. The working fluid is vaporized in a heat exchanger and used to turn a turbine. The water is then injected back into the ground to be reheated. The water and the working fluid are kept separated during the whole process, so there is minimal or no contamination. The advantage of the binary cycle plant is that it can operate with lower temperature water by using working fluids that have an even lower boiling point than water. Binary power plants are available in smaller scales such as 200 to $1,000 \mathrm{~kW}$.

- Hot Dry Rock (HDR) geothermal production utilizes high temperature rocks found deep (several kilometers) below the surface by pumping high-pressure water down a borehole into a heat zone. The water captures the heat of the rock by traveling through fractures until it is forced out a second borehole and used to generate electricity. Once the water has cooled, it is pumped back underground to heat up again. This process is most easily utilized in locations with natural geothermal systems with existing cracks or pore spaces.

- Engineered or Enhanced Geothermal Systems (EGS) are similar to HDR systems. In locations where there are few cracks and connected pore spaces, or little to no cracks or connectivity, cracks can be created or enhanced. The advantage of HDR or EGS is that geothermal resources can be captured for production in non-tectonically active regions. This 
technology is derived from the oil and gas industry, but it currently is very new and expensive for geothermal power production.

\section{Geothermal Energy Analysis Approach}

In the 2005 DoD Renewable Energy Assessment, the Navy's Geothermal Office was responsible for the DoD geothermal power assessment. That task was subcontracted to Innovative Technical Solutions, Inc. (ITSI). The Navy and ITSI ranked installations based on their assessment of potential. Funding limited the number of sites that could be inspected and assessed for the DoD study. ITSI visited some locations and collected information through site inspections (for indicators such as hot springs), field measurements, and review of temperature readings from water well drilling logs. This information was compiled in site reports and used to recommend further analysis, typically the drilling of test wells to measure temperature and assess subsurface conditions. Drilling test wells is the next in a progression of steps and is generally very expensive, on the order of \$1 million per well.

The utility-grade geothermal assessment included 18 installations identified by DoD. Of those installations, five sites were found to have high potential for utility-grade systems. Yuma Proving Ground was one of the "utility-scale" geothermal power projects evaluated in the DoD study. According to the report:

Yuma Proving Ground has little neotectonic or igneous activity, and local faults have slow slip rates. There are no apparent surface geothermal indicators and only moderate heat flow in this region. However, geothermometry and selected wells in the region suggest localized areas of geothermal potential. Yuma Proving Ground is herein considered to have low utility-grade geothermal potential although selected well data suggest further localized investigations are warranted.

This analysis utilized the information available from the DoD study, in addition to other readily available sources, to determine if the following conditions exist that demonstrate utility-grade geothermal potential:

- Existing power plant operation or developer activity

- One or more wells tested with temperatures in excess of $212^{\circ} \mathrm{F}\left(100^{\circ} \mathrm{C}\right)$ logged downhole (at depths less than 3,000 m)

- Demonstrated high fluid flow rates on the order of 1,000 gallons per minute (gpm) per MW

- Heat flow rates greater than $80 \mathrm{~mW} / \mathrm{m}^{2}$ (milliWatts per square meter)

- Other exploration data and information available $\left(>=212^{\circ} \mathrm{F}\left(100^{\circ} \mathrm{C}\right)\right.$ not proven)

Since the 2005 DoD geothermal assessment, additional research and development has been completed on other geothermal development techniques that may be applicable to additional installations. We attempt to interpret this new information when evaluating the economic viability.

\section{Geothermal Resource Characterization}

Geothermal resources include hot springs, geysers, and underground resources of pressurized water and steam accessible via wells, as well as dry steam, hot water, hot dry rocks, and low-temperature 
geothermal heat. A known geothermal resource area is an area in which the geology, nearby discoveries, competitive interests, or other indicators show that potential for extraction of geothermal steam or associated geothermal resources is sufficient to warrant consideration.

For commercial use, it is necessary to have a geothermal reservoir capable of providing hydrothermal (hot water and steam) resources with sufficiently high flow rates. Successful geothermal electrical power generation requires fluid flow rates equal to or greater than 1,000 gallons per minute (gpm) per MW. For example, $1.5 \mathrm{MW}$ of electricity at a reservoir temperature of $300^{\circ} \mathrm{F}\left(149^{\circ} \mathrm{C}\right)$ requires a flow rate of about 1,000 gpm, or about 1,029,000 barrels/month (McKenna 2006). Heat flow values above $80 \mathrm{~mW} / \mathrm{m}^{2}$ are considered characteristic of a feasible geothermal resource. Productive heat flows are generally greater than $150 \mathrm{~mW} / \mathrm{m}^{2}$ (Blackwell et al, 2003).

Yuma Proving Ground lies outside any known or potential geothermal resource area. Review of the Idaho National Lab’s (INL) California Geothermal Resource Map (Figure C-1) shows the closest known geothermal resource area is located to the west of Yuma, AZ in Imperial County, CA with well temperatures in excess of $212^{\circ} \mathrm{F}\left(100{ }^{\circ} \mathrm{C}\right)$. There are no known resources identified within the boundaries of Yuma Proving Ground. According to the 2004 Geothermal Map of the United States from Southern Methodist University (SMU) (Figure C-2), heat flows in and around Yuma Proving Ground are in the range of $85-89 \mathrm{~mW} / \mathrm{m}^{2}$. In addition, the map from the ITSI report shows two wells near Yuma Proving Ground - one with temperatures in excess of $120^{\circ} \mathrm{F}$ at $3 \mathrm{~km}$ and the other with temperatures less than $120^{\circ} \mathrm{F}$ at an unknown depth, which suggests a feasible, although not productive, geothermal resource.

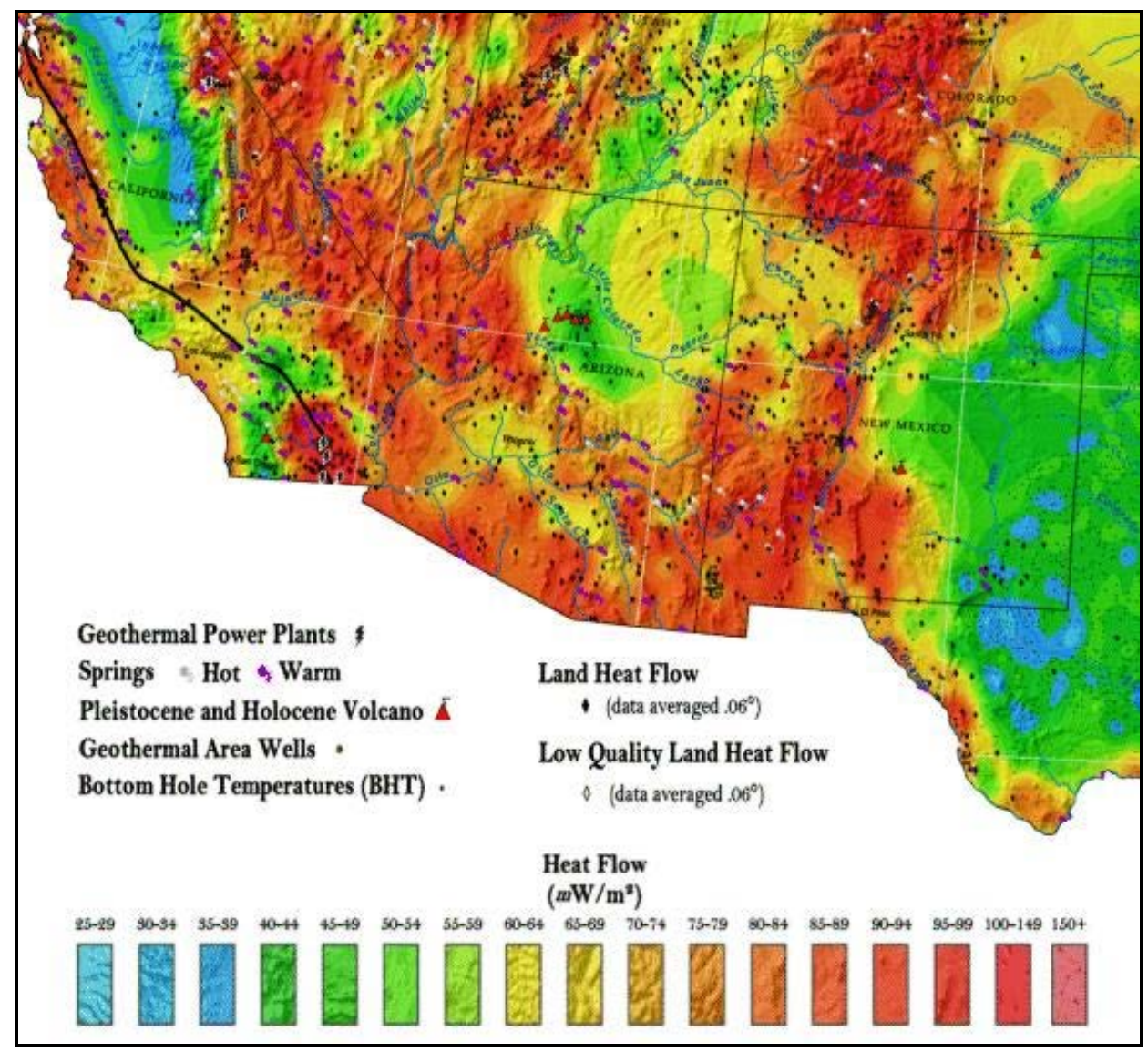

Figure C- 1: SMU Geothermal Map of the US 


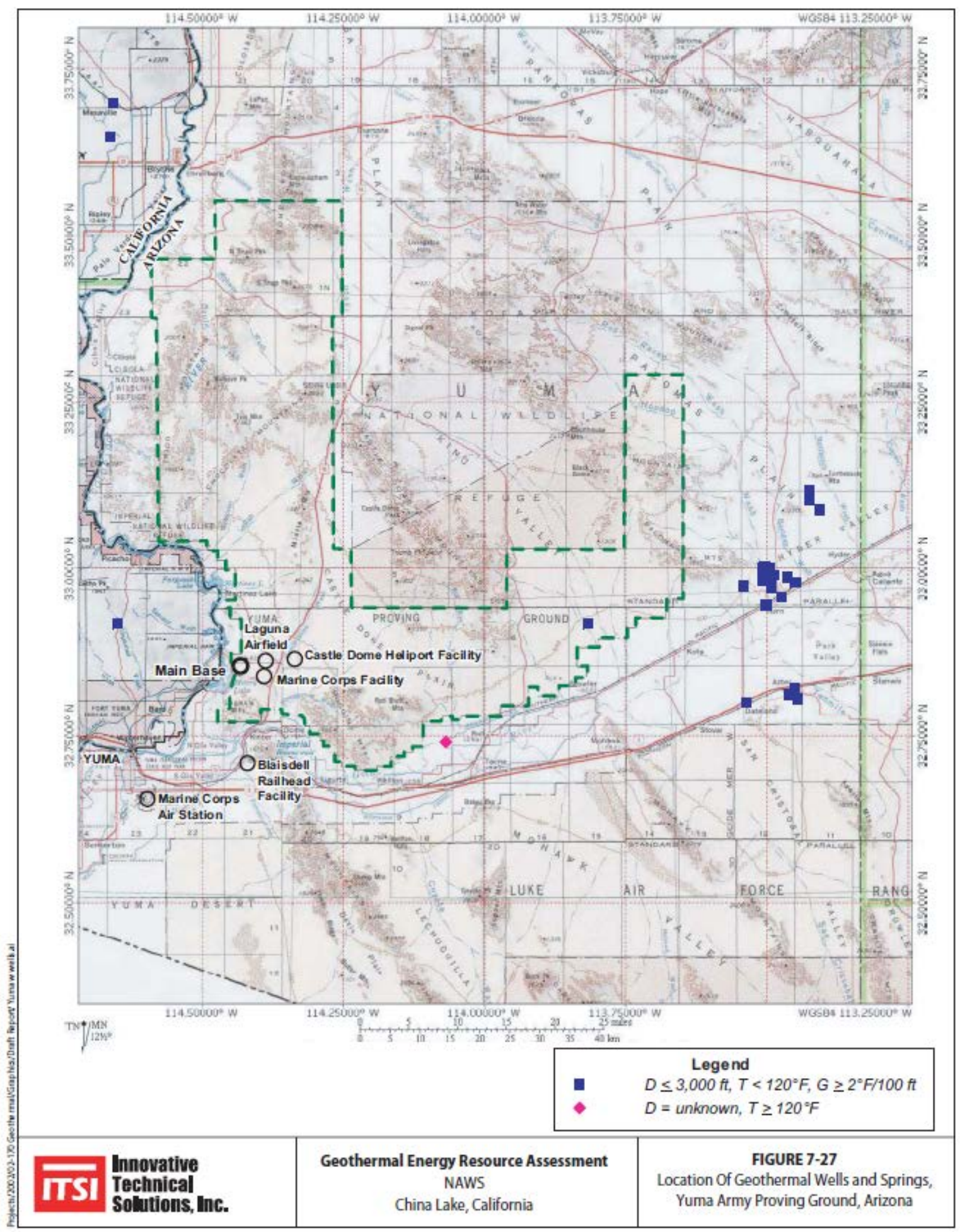

Figure C- 2: Geothermal Temperatures from the DOD Geothermal Assessment (ITSI 2003) 
Utility-grade geothermal energy requires temperatures in excess of $212^{\circ} \mathrm{F}\left(100{ }^{\circ} \mathrm{C}\right)$ at depths less than $3 \mathrm{~km}$. The geothermal temperature at depth $(3 \mathrm{~km})$ map for the Continental United States from Idaho National Laboratory (INL) shows the part of the installation near existing facilities and running along the Arizona/California border at $212-257^{\circ} \mathrm{F}\left(100-125^{\circ} \mathrm{C}\right)$. The majority of the installation located to the east of the facilities shows the temperature at depth to be $257-302{ }^{\circ} \mathrm{F}\left(125-150{ }^{\circ} \mathrm{C}\right)$. These temperatures are marginally sufficient at shallow depth for economic generation using current technology. Drilling is necessary to know the actual temperature at depth before proceeding with a project.

Geothermal electrical generation plants are currently operating in Alaska, California, Nevada, Utah, and Hawaii with proposed projects in Arizona, Oregon, Idaho, New Mexico, Texas, Washington, and Wyoming (GEA 2006). There are no geothermal power plants in Arizona at present. A project is currently under development a Clifton Hot Springs, with a projected potential of about 20 MW. Northern Arizona University is conducting preliminary studies on a potential project as well (Richter 2007).

\section{Geothermal Power Plants: Economic and Other Analysis Parameters}

This analysis included current Federal geothermal incentives - a 2.1 $\mathrm{\$} / \mathrm{kWh}$ renewable energy production credit and a 5-year accelerated depreciation. There is also a possibility that a geothermal project could benefit from the sales of renewable energy credits (RECs) to utilities needing to meet Arizona's Renewable Portfolio Standard requirements. However, based upon the previous APS RFP, DG RECs from geothermal electricity were valued less highly than any other renewable energy technology.

The analysis assumed that electricity transmission lines located on or near the potential Yuma Proving Ground geothermal development area would be available to transmit power without substantial additional investment.

For the economic evaluation of the geothermal resource potential, the on-peak electric rate of $2.9 \$ / \mathrm{kWh}$ was utilized. The economics were also run to determine the minimum price per $\mathrm{kWh}$ required to earn a sufficient internal rate of return (IRR) for independent power producers (IPP).

\section{Installed Costs of Technology}

Geothermal power costs are influenced by capital costs for land, drilling, and the physical plant. The analysis also needs to consider the cost of operation and maintenance (O\&M), the amount of power generated, and the market value of the power. Capital costs range from $\$ 1,500$ to $\$ 4,000$ per installed kW. Capital costs for flash steam plants tend to be less expensive than binary plants. Plant life spans are typically 30 to 45 years.

Capital costs include:

- Initial development work: land leasing, exploration, permitting, test well costs

- Infrastructure: roads, water supply, utilities

- Well field drilling: production wells in addition to already drilled confirmation wells

- Steam and brine gathering system: pipes and brine separation equipment

- Power plant: physical equipment for energy conversion, including substation 
- Interconnection: link of the power plant substation to the transmission corridor

- Soft costs: developers’ fees, overhead, financing costs, legal fees, etc.

Geothermal wells are drilled to depths of 200 to 1,500 meters for low- and medium-temperature systems. For high-temperature systems, wells are drilled 700 to 3,000 meters deep. Each well costs \$1 million to \$4 million to drill, and a geothermal field may consist of between 10 and 100 wells.

Operating plants at over 90\% capacity will result in higher O\&M costs. Larger plant size means lower per-kWh operating costs. Operating costs range from 0.4 to $2.6 \mathbb{\$} / \mathrm{kWh}$ for conventional geothermal power plants.

According to existing data, Yuma Proving Ground may have elevated temperatures at economic depths (less than 3,000 m) and sufficient heat flow rates for geothermal energy production. The economic analysis was run with the optimistic assumption of $302{ }^{\circ} \mathrm{C}\left(150{ }^{\circ} \mathrm{F}\right)$ at 3,000 meters based on the 2004 Geothermal Map of the United States from the Southern Methodist University (SMU) Geothermal Lab. See Table C-1 below for all other economic assumptions.

Table C- 1: Performance, Cost, and Economic Characteristics

\begin{tabular}{|c|c|}
\hline Assumed temperature at $3,000 \mathrm{~m}$ & $302^{\circ} \mathrm{F}\left(150^{\circ} \mathrm{C}\right)$ \\
\hline Capacity Factor & $96 \%$ \\
\hline Technology Type & Binary \\
\hline Project Size & $15 \mathrm{MW}$ \\
\hline Estimated Annual Energy Production & 126,144 MWh \\
\hline Average Cost of Energy & $2.92 \$ / k W h$ \\
\hline Total Capital Cost & $\$ 6261.4 / \mathrm{kW}$ \\
\hline
\end{tabular}

Further details on the analysis methodology and the economic and incentive parameters are documented in Appendix A of this report.

\section{Findings: Geothermal Power Plant Opportunities}

The resource analysis for Yuma Proving Ground found a low to medium potential for utility-grade geothermal electricity production, with no cost-effective projects identified. The biggest factor in the capital cost is the number of expensive wells required to produce adequate hot water and steam resources at sufficient flow rates. The depth of the wells and number of wells needed to get adequate geothermal resource for electricity generation at this location yielded a project that would cost more than the current rates paid by Yuma Proving Ground. The resource estimations need to be confirmed with actual well data and further geological studies. But given the high expense and risk to confirm this resource, this step would not be recommended at this time.

The ECIP analysis based upon electricity valued at $2.92 \$ / \mathrm{kWh}$ yielded a payback period of 330 years, with an SIR 0.0. (An SIR of 0.0 indicates there are no savings realized in the analysis. An SIR of 1.0 is generally required for ECIP projects.) Under the IPP scenario, the value of the energy generated would need to be $9.8 \$ / \mathrm{kWh}$ to achieve a $10 \%$ IRR (minimum IRR for IPP to be interested). Additionally, if the renewable energy credits (RECs) could be sold at a price of $6.88 \mathrm{c} / \mathrm{kWh}$, a project could be economical. The potential for REC sales is possible because Arizona utilities need to meet 
the Renewable Portfolio Standard, but the value is unknown. However, during the previous RFP for DG RECs, APS was willing to pay $2 \mathbb{\$} / \mathrm{kWh}$ over the course of a 20 year contract.

This assessment, which is focused on utility-scale electricity generation, did not examine the potential for direct-use applications of geothermal resources such as space heating, aquaculture, and industrial processes.

\section{Geothermal Power Plants: Next Steps}

The economic analysis for geothermal electricity at Yuma Proving Ground relied upon many assumptions. The resource data for this assessment is based on heat flow and temperature at depth maps from SMU and INL. Actual wells would need to be drilled to accurately determine the temperature at depth. In the future, updated resource assessments may be produced.

Higher utility rates in the future would make a geothermal project more economically feasible. Alternatively, if the RECs are sold at a price of $6.88 \leftarrow / \mathrm{kWh}$, a project could be economical. The potential for REC sales is possible because Arizona utilities need to meet the Renewable Portfolio Standard, but the value is unknown but expected to be low based upon past RFP for DG RECs. Additional State or Federal incentives could also bring the kWh price of a project down.

HDR or EGS have potential for the future, but those technologies are new and costly. Consideration could be given to the potential of developing geothermal reservoirs from co-produced hot waters from oil and gas production. A review of existing oil and gas well production data shows high water production from oil and gas wells. If this were to be pursued, the water flow rates for the areas around Yuma Proving Ground would need to be investigated further. It is possible that a nearby producer could be interested in collaborating with Yuma Proving Ground. If this scenario presents itself, the economics of a co-production project should be considered.

Because the geothermal resource near Yuma Proving Ground is marginal, no further action should be taken in pursuing a geothermal project unless the overall situation changes dramatically. Factors that could change the situation include:

- New data demonstrating higher temperatures at depths that can be harvested,

- An oil or gas producer found near the post with fluid production at elevated temperatures that could be utilized for co-production,

- A reduction in costs for the capture of geothermal energy utilizing newer technologies,

- A reduction in cost for drilling to deeper reservoirs of geothermal heat,

- A substantial increase in energy prices paid by Yuma Proving Ground, and/or

- A REC at a rate that would justify geothermal resource exploration.

\section{Geothermal Power Plant Sources of Information}

Allison, Lee. Arizona Geological Survey. Tucson, AZ, Personal communications. May 2009.

Blackwell, David D, et al. 2003. Geothermal Resource Analysis and Structure of Basin and Range Systems, Especially Dixie Valley Geothermal Filed, Nevada. Department of Geological Sciences 
Southern Methodist University. June 2003. http://www.osti.gov/energycitations/servlets/purl/813485smnwbs/native/813485.PDF.

Brasz, Joost J., Bruce P. Biederman, and Gwen Holdmann. Power Production from a Moderate Temperature Geothermal Resource. GRC Annual Meeting September 25-28, 2005. Reno, NV. http://www.yourownpower.com/Power/grc\%20paper.pdf.

Campbell, R.G., and M.M. Hatter. 1991. Design and operation of a geopressured geothermal hybrid cycle power plant: Final report vol. I, 180 p. and vol. II, 172. Eaton Operating Company, Inc. and United States Department of Energy, The Ben Holt Co.

Fleischmann, Daniel J. September 2006. Geothermal Resource Development Needs in Arizona. Geothermal Energy Association. http://www.geoenergy.org/publications/reports/Arizona\%20Geothermal\%20Report\%20Sept\%2025\%202006.pdf

GeothermEx, Inc. Public Interest Energy Research Report. New Geothermal Site Identification and Qualification. California Energy Commission. April 2004. http://www.geothermex.com/CECPIER_Report_New_Geothermal_Site_Identification_and_Qualification.pdf.

Hance, Cédric Nathanaël. Factors Affecting Costs of Geothermal Power Development. Geothermal Energy Association. August 2005. http://www.geo-

energy.org/publications/reports/Factors\%20Affecting\%20Cost\%20of\%20Geothermal\%20Power\%20Dev elopment\%20-\%20August\%202005.pdf.

Idaho National Laboratory (INL). 2005. Temperature at Depth Maps for the Continental United States. Estimated Temperature at 3 Kilometers. April 2005. http://geothermal.id.doe.gov/maps/.

Innovative Technical Solutions (ITSI). 2003. Geothermal Energy Resource Assessment on Military Lands. Prepared for NAWS China Lake. Contract No. N68936-02-R-023. October 2003. http://www.geothermal.org/GEO_0001.PDF.

McKenna, Jason R. 2006. U.S. Army Corps Engineer Research \& Development Center. Increasing Electrical Power Capacity for Military Applications. US Army Corps Engineer Research \& Development Center. http://www.smu.edu/geothermal/Oil\&Gas/Mckenna_Army\%20Corps.pdf.

MIT-led Interdisciplinary Panel. The Future of Geothermal Energy: Impact of Enhanced Geothermal Systems (EGS) on the United States in the 21st Century. DOE. 2006.

http://geothermal.inl.gov/publications/future_of_geothermal_energy.pdf.

Petty, Susan. Engineering Geothermal Systems in Oil \& Gas Reservoirs. Presentation at the Southern Methodist University (SMU) Geothermal Lab conference on Geothermal Energy Utilization Associated with Oil and Gas Development. June 12 and 13, 2007.

http://www.smu.edu/geothermal/Oil\&Gas/2007/Petty_Susan\%20Engineering\%20Geothermal\%20System s\%20in\%20Reservoirs.pdf.

Rafferty, Kevin. Geothermal Power Generation: A Primer on Low-temperature, Small-scale Applications. Geo-Heat Center. January 2000. http://geoheat.oit.edu/pdf/powergen.pdf.

Richter, A, 2007. Glitnir United States-Geothermal Energy Market Report. http://docs.glitnir.is/media/files/Glitnir_USGeothermalReport.pdf. 
Shibaki, Masashi. Geothermal Energy for Electric Power. A Renewable Energy Policy Project (REPP) Issue Brief. December 2003. http://www.crest.org/articles/static/1/binaries/Geothermal_Issue_Brief.pdf.

Southern Methodist University Geothermal Lab (SMU). 2004. Geothermal Map of the United States (heat flow map).

http://www.smu.edu/geothermal/heatflow/geothermal_all_us_clipped_150dpi_pagesize_legend.gif. 
Renewable Energy Opportunities at Yuma Proving Ground, AZ Pacific Northwest National Laboratory, June 2010 


\section{APPENDIX D}

\section{Analysis of Ground Source Heat Pump Opportunities}


58 Renewable Energy Opportunities at Yuma Proving Ground, AZ Pacific Northwest National Laboratory, June 2010 


\section{Appendix D: Analysis of Ground Source Heat Pump Opportunities}

\section{Ground Source Heat Pump Technology}

Ground source heat pumps (GSHPs) use the stable temperatures of the sub-surface ground and groundwater to improve the coefficient of performance of heating and cooling applications for buildings. Common GSHP configurations include open-loop, horizontal closed-loop, and vertical closed-loop.

- Open-loop systems use open wells or bodies of water as direct heat transfer mediums to provide cool temperatures in the summer and warm temperatures in the winter. Heat transfer is only needed once, at the building, because groundwater is used directly, and the limited drilling and trenching results in a lower first cost.

- Closed-loop systems use heat transfer fluid inside a sealed pipe to exchange heat with the earth. Closed-loop systems have lower pumping requirements and are more efficient than open-loop systems. However, soil type and moisture content is more critical to the performance of these systems, and the trenching and drilling significantly increases first cost. Horizontal loops require trenching, so that all the piping lies at the same depth in the ground.

- Vertical closed-loop GSHPs are deployed in vertical boreholes, and are the most efficient configuration.

GSHPs are applicable in almost any building with both heating and cooling. They can be used in buildings as small as 100 square feet, or up to 1 million square feet. Multiple GSHPs can be used in a single building to meet the load, or the same ground loop can be shared between buildings.

To install GSHPs at a building, the surrounding area will have certain prerequisites, depending on the type of GSHP. Open-loop GSHPs need a water source and sink. The source can be a well or open body of water that will not be significantly impacted by the extraction of the water. To replenish this water, the sink can be a secondary well, the open body of water used as the source, another body of water, or a storm drain. Water volume requirements depend on the size of GSHP installed, but typically between 1.5 and 3.0 gallons per minute are needed per cooling ton. This greatly affects the feasibility of open-loop systems in some areas, as do local codes and regulations. Many locales do not want to risk groundwater depletion or contamination.

Horizontal closed-loop GSHPs have a different limiting factor: sufficient land area. The heat transfer for these systems occurs in pipes laid in trenches that are between 100 and 400 feet long per cooling ton, spaced between 6 and 12 feet apart. The soil characteristics and number of pipes per trench determine the pipe length; more pipes (up to six) per trench save land space but require greater lengths of pipe per ton of cooling.

Where significant land area or water volumes are not available, vertical closed-loop GSHPs may be the only option. In these systems, the heat transfer pipes are placed vertically in the ground, at depths of between 75 and 300 feet. Some land area is still required, because the pipe wells need to be spaced at least 15 to 20 feet apart, and 200 to 600 feet of piping are needed per cooling ton. 


\section{Ground Source Heat Pump Analysis Approach}

For the purposes of this assessment, GSHPs were evaluated for various building sizes, vintages, and uses that are typically found on Army sites. Open-loop, horizontal closed-loop, and vertical closedloop configurations were analyzed for all building types.

Administration- and barracks-type buildings with varying building characteristics were entered into the Facility Energy Decision System (FEDS) building energy model to determine cost-effectiveness for GSHPs in a range of "typical” buildings. Site-specific TMY (typical meteorological year) weather data and soil/ground characteristics were used in the analysis, along with Yuma Proving Ground's current energy prices. The weather data used for this analysis came from the Yuma International Airport. Because of a lack of reliable data regarding the soil characteristics in the area, the following values were used in the calculations:

- Soil thermal diffusivity: 0.02

- Overburden depth: $100 \mathrm{ft}$

- Bedrock thermal conductivity: $1.4 \mathrm{Btu} /\left(\mathrm{hr} \cdot \mathrm{ft} \cdot{ }^{\circ} \mathrm{F}\right)$

The values are sufficient to provide an initial screening tool for potential projects but actual testing to evaluate soil characteristics will be necessary before actual project costs and returns can be determined.

In this assessment, FEDS was used to determine which GSHP configurations are cost-effective for each building type analyzed. This approach provides a first cut to determine whether GSHPs might be economically feasible at Yuma Proving Ground. It narrows the range of possibilities for potential projects, resulting in a list of building types that are worthwhile to investigate in more detail.

The model does not consider site limitations like land area or water source availability. The assumption is that there are sufficient thermal sources/sinks in place.

\section{Ground Source Heat Pump Resource Characterization}

The following building characteristics were used to represent a wide variety of typical administrative and barracks buildings found on an Army site.

- Size:

o $100,000 \mathrm{ft}^{2}$ (large)

o $\quad 10,000 \mathrm{ft}^{2}$ (medium)

o $500 \mathrm{ft}^{2}$ (small)

- Vintage (this affects many model assumptions, including the levels of insulation)

o 1945 (old)

o 1975 (mid-aged)

o 2000 (new)

- Heating type

o Fuel oil boiler with air handling units

o Fuel oil boiler with fan coil units

o Fuel oil furnace

o Electric furnace

- Cooling type 
o Single building chiller with air handling units

o Single building chiller with fan coil units

o Package AC / DX unit

o Window / wall unit

The building characteristics analyzed represent most of the buildings found typically on an Army site. Therefore, this assessment should adequately account for any buildings that are of primary retrofit interest.

In general, conditions favoring replacement of existing heating and cooling systems with GSHPs include:

- Replacing old equipment. Equipment at the end of its useful life that will soon be replaced provides further economic incentive for GSHP installations, particularly if existing ductwork can be reused.

- $\quad$ More extreme climates. Cold winters, hot summers, or large daily temperature swings allow GSHPs to operate more efficiently than other electric cooling and heating systems. The cost of heating operation is comparable to non-electric heating systems.

- High cost of non-electric fuels. If electricity is less than approximately 3.5 times as expensive per Btu than other fuels, GSHPs will generally be cost-effective. If no other fuel option is available and electric costs are high, GSHPs will be less expensive to operate than air-source heat pumps.

GSHPs are often not cost-effective in a building that:

- Does not have both cooling and heating. A building needs to be both heated and cooled to take advantage of the GSHP efficiency in both modes. However, most of the savings are realized in the heating mode, so buildings with no cooling can still benefit from GSHPs.

- Requires installation of new air distribution network. Installing an entirely new air distribution system in addition to the conditioning equipment generally adds too much cost for a GSHP retrofit

- Is newer. Newer buildings (less than about 4 years old) generally have fairly efficient equipment (or at least the performance has not yet degraded significantly). As a result, premature replacement with a GSHP is generally uneconomic. In addition, the building envelope tends to be better, lengthening payback duration.

- Is located in a mild climate. Buildings in fairly mild climates do not have the temperature extremes that make the ground loop advantageous. A standard air-source heat pump would probably suffice.

- Uses an air-source heat pump. An air-source heat pump has many of the benefits of a GSHP except in extreme temperature conditions. These extreme temperature conditions often are not sufficient to justify replacement. 
- Is connected to a central energy plant (CEP) (unless the CEP will be abandoned). Although central energy systems are often consider to be large energy wasters, on a building-bybuilding basis (which does not account for distribution losses) it is difficult to justify the installation of a GSHP. Centralized chiller plants can use larger, more efficient watercooled units and can stage several chillers to run closer to full load (which is the most efficient mode).

\section{Ground Source Heat Pumps: Economic and Other Analysis Parameters}

FEDS allows two primary financing options: appropriated funding (using Energy Conservation Investment Program, or ECIP, funds) and alternative financing (utility energy services contract (UESC) or energy saving performance contract (ESPC)). The parameters for alternative financing can be adjusted to match the options available to the site. For this assessment, a project life of 25 years and a third-party interest rate of $5 \%$ were used.

FEDS incorporates the site's electric rate schedule and energy costs to determine fuel costs and savings for GSHP retrofits. Yuma Proving Ground is served primarily through the Western Area Power Administration (WAPA) via the Wellington-Mohawk Irrigation and Drainage District (WMIDD), as well as receiving a small quantity of energy from Arizona Public Services (APS). Because Yuma Proving Ground's energy consumption consistently exceeds the amount allocated to it through their primary contracts, it is assumed that the introduction of GSHPs will impact the net amount of supplemental power that Yuma Proving Ground purchases from WMIDD (outlined in contract number 98-DSR-10865). This supplemental energy has a cost of $4.68 \mathrm{\$} / \mathrm{kWh}$.

In addition, it is likely that the bulk of electrical savings from the introduction of GSHPs would occur in the summer, when electricity consumption is at its highest. On the other hand, electricity consumption would increase in the winter because of fuel switching (from fossil fuels to electricity). The heating fuels that would potentially be displaced by GSHPs are fuel oil and propane gas. The prices for these fuel types tend to be highly volatile so an average value was determined by using billing data from the last 2 to 3 years to calculate an approximate average value.

- Costs of displaced fossil fuels

o Fuel Oil: \$14.00 per MMBtu

o Propane : $\$ 18.00$ per MMBtu

The average installed costs of GSHPs are shown in Table D-1. The difference in costs reflects economies of scale working in favor of larger installations. Where fewer or smaller units are being installed, the price increases comparatively with a similar technology. Costs are only shown for technologies that were found to be cost-effective in this analysis. 
Table D- 1: Average Installed Costs for GSHPs, \$/sf

\begin{tabular}{||c|c|c|c|c|}
\hline \hline \multirow{2}{*}{ Building Type and Size } & \multicolumn{4}{|c|}{ ECIP Funding } \\
\cline { 3 - 6 } & $\begin{array}{c}\text { Open-Loop } \\
\text { GSHP }\end{array}$ & $\begin{array}{c}\text { Horizontal } \\
\text { GSHP }\end{array}$ & $\begin{array}{c}\text { Vertical } \\
\text { GSHP }\end{array}$ \\
\hline \multirow{3}{*}{$\begin{array}{c}\text { Administration } \\
\text { Buildings }\end{array}$} & Small & n/a* & 26.35 & n/a \\
\cline { 2 - 6 } & Medium & n/a & n/a & n/a \\
\cline { 2 - 6 } & Large & n/a & n/a & n/a \\
\hline \multirow{3}{*}{ Barracks } & Small & n/a & 26.51 & n/a \\
\cline { 2 - 6 } & Medium & n/a & n/a & n/a \\
\cline { 2 - 6 } & Large & n/a & n/a & n/a \\
\hline \hline
\end{tabular}

*only systems with SIR greater than 1 were evaluated

\section{Findings: Ground Source Heat Pumps}

FEDS determined that GSHPs are generally not cost-effective at Yuma Proving Ground. This is mainly because of its cooling dominated climate. To take full advantage of the ground's constant temperature and to offset the high initial costs of GSHP systems, it is necessary to have balanced heating and cooling loads.

Despite Yuma Proving Ground's relatively unsuitable environment, the analysis determined a few instances where the installation of GSHPs would be cost-effective. This occurred when a project was funded via ECIP and when the project was applied to a small building that receives its cooling through an air-source chiller combined with an air distribution system within the building. Although not impossible, this combination of attributes is unlikely to occur in most buildings of this type.

Table D-2 lists the building configurations for which ECIP funded, horizontal-loop GSHP projects may be economical (no other ground loop configuration or funding mechanism was found to be costeffective): 
Table D- 2 : Yuma Proving Ground GSHP Opportunities Based on Existing Building Characteristics

\begin{tabular}{|c|c|c|c|c|c|c|c|}
\hline Use Type & Age & $\begin{array}{l}\text { Size } \\
\left(\mathbf{f t}^{2}\right)\end{array}$ & $\begin{array}{l}\text { Heating } \\
\text { Technology }\end{array}$ & $\begin{array}{c}\text { Cooling } \\
\text { Technology }\end{array}$ & $\begin{array}{c}\text { Simple } \\
\text { Payback } \\
\text { (Years) }\end{array}$ & SIR & $\begin{array}{c}\text { Installed } \\
\text { Capital Cost }\end{array}$ \\
\hline Administration & Old & $\begin{array}{l}500- \\
5,000 \\
\end{array}$ & Propane Boiler & AHU with Chiller & 13 & 1.1 & $\$ 17,799$ \\
\hline Administration & Old & $\begin{array}{c}500- \\
5,000 \\
\end{array}$ & Oil Boiler & AHU with Chiller & 13 & 1.1 & $\$ 17,791$ \\
\hline Administration & Old & $\begin{array}{c}500- \\
5,000\end{array}$ & Propane Furnace & AHU with Chiller & 14 & 1 & $\$ 17,788$ \\
\hline Administration & Old & $\begin{array}{l}500- \\
5,000\end{array}$ & Oil Furnace & AHU with Chiller & 14 & 1 & $\$ 17,788$ \\
\hline Administration & Mid-Aged & $\begin{array}{l}500- \\
5,000\end{array}$ & Propane Boiler & AHU with Chiller & 9.1 & 1.6 & $\$ 12,481$ \\
\hline Administration & Mid-Aged & $\begin{array}{l}500- \\
5,000\end{array}$ & Oil Boiler & AHU with Chiller & 9.1 & 1.6 & $\$ 12,475$ \\
\hline Administration & Mid-Aged & $\begin{array}{l}500- \\
5,000\end{array}$ & Propane Furnace & AHU with Chiller & 9.8 & 1.5 & $\$ 12,470$ \\
\hline Administration & Mid-Aged & $\begin{array}{l}500- \\
5,000\end{array}$ & Oil Furnace & AHU with Chiller & 9.8 & 1.5 & $\$ 12,470$ \\
\hline Administration & Mid-Aged & $\begin{array}{c}500- \\
5,000 \\
\end{array}$ & Electric Furnace & AHU with Chiller & 10.1 & 1.4 & $\$ 12,470$ \\
\hline Administration & New & $\begin{array}{l}500- \\
5,000 \\
\end{array}$ & Propane Boiler & AHU with Chiller & 7.5 & 2 & $\$ 10,187$ \\
\hline Administration & New & $\begin{array}{l}500- \\
5,000\end{array}$ & Oil Boiler & AHU with Chiller & 7.4 & 2 & $\$ 10,182$ \\
\hline Administration & New & $\begin{array}{l}500- \\
5,000\end{array}$ & Propane Furnace & AHU with Chiller & 8 & 1.8 & $\$ 10,177$ \\
\hline Administration & New & $\begin{array}{l}500- \\
5,000\end{array}$ & Oil Furnace & AHU with Chiller & 7.9 & 1.8 & $\$ 10,177$ \\
\hline Administration & New & $\begin{array}{l}500- \\
5,000\end{array}$ & Electric Furnace & AHU with Chiller & 8.2 & 1.8 & $\$ 10,177$ \\
\hline Barracks & Mid-Aged & $\begin{array}{l}500- \\
5,000\end{array}$ & Propane Boiler & AHU with Chiller & 10.1 & 1.4 & $\$ 13,165$ \\
\hline Barracks & Mid-Aged & $\begin{array}{l}500- \\
5,000 \\
\end{array}$ & Oil Boiler & AHU with Chiller & 10.1 & 1.4 & $\$ 13,159$ \\
\hline Barracks & Mid-Aged & $\begin{array}{c}500- \\
5,000 \\
\end{array}$ & Propane Furnace & AHU with Chiller & 10.8 & 1.3 & $\$ 13,155$ \\
\hline Barracks & Mid-Aged & $\begin{array}{l}500- \\
5,000\end{array}$ & Oil Furnace & AHU with Chiller & 10.7 & 1.4 & $\$ 13,155$ \\
\hline Barracks & Mid-Aged & $\begin{array}{l}500- \\
5,000 \\
\end{array}$ & Electric Furnace & AHU with Chiller & 11 & 1.3 & $\$ 13,155$ \\
\hline Barracks & New & $\begin{array}{l}500- \\
5,000\end{array}$ & Propane Boiler & AHU with Chiller & 10.4 & 1.4 & $\$ 13,356$ \\
\hline Barracks & New & $\begin{array}{c}500- \\
5,000\end{array}$ & Oil Boiler & AHU with Chiller & 10.3 & 1.4 & $\$ 13,350$ \\
\hline Barracks & New & $\begin{array}{l}500- \\
5,000 \\
\end{array}$ & Propane Furnace & AHU with Chiller & 11.1 & 1.3 & $\$ 13,346$ \\
\hline Barracks & New & $\begin{array}{l}500- \\
5,000\end{array}$ & Oil Furnace & AHU with Chiller & 10.9 & 1.3 & $\$ 13,346$ \\
\hline Barracks & New & $\begin{array}{c}500- \\
5,000 \\
\end{array}$ & Electric Furnace & AHU with Chiller & 11.3 & 1.3 & $\$ 13,346$ \\
\hline
\end{tabular}

Lastly, a preliminary analysis of the impact of a production based incentive on the economic feasibility of GSHP projects was executed by PNNL using the 2007 production based incentive values $(0.043-0.048 \$ / \mathrm{kWh})$ offered by APS during their previous RFP. The interaction between production credits and project feasibility is not straightforward because of the complex relationship between the technology and fuels being replaced, the expected heating and cooling loads, and the cost of energy. The analysis indicates that with the available incentives, GSHPs would continue to be uneconomic, although there was a slight improvement in the economics for the building types 
listed in the previous section. To take full advantage of available production incentives for GSHPs, careful analysis would have to be carried out on a project-by-project basis.

\section{Ground Source Heat Pumps: Next steps}

The total potential energy savings resulting from the GSHP retrofits for Yuma Proving Ground cannot be determined at this point because the results are not tied to specific buildings on the site. This assessment is intended to show where potential may exist, to proceed with a promising detailed investigation.

Yuma Proving Grounds may want to reevaluate GSHPs in certain buildings on-site. Site-specific soil conductivity data, failed heating and cooling equipment, and major renovations all present opportunities for further investigation into GSHP potential. Available incentives or increased savings from adjusted fuel costs may also result in cost-effective projects. Arizona's Renewable Portfolio Standard (RPS) recognizes GSHPs as a renewable resource, so development assistance or renewable energy credit sales may be available. Preliminary analysis into the impact of the RPS on the economic viability of GSHP projects was executed by PNNL using the 2007 values for the production based incentive offered by APS (the only utility for which REC sales would be applicable under the RPS). This analysis indicated that the current level of incentives available for GSHPs would not result in any other prototype buildings becoming cost-effective but did show a slight improvement in the economics of the potential projects listed in the previous section.

In addition, new construction is still an option; retrofit GSHP installations (what was analyzed here) are more expensive. When a new site is being excavated, test the soil to determine site-specific conductivity and other characteristics. GSHPs should always be considered for new construction.

\section{Ground Source Heat Pump Sources of Information}

Office of Ground Water. 1999. “Ground Water Atlas of the United States.” US Geological Survey. Reston, Virginia. http://pubs.usgs.gov/ha/ha730/ch_n/N-AKunconsolidated.html.

Federal Technology Alert. "Ground Source Heat Pumps Applied to Federal Facilities - Second Edition.” Federal Energy Management Program. DOE/EE-0245. March 2001.

http://www1.eere.energy.gov/femp/pdfs/FTA_gshp.pdf. 
Renewable Energy Opportunities at Yuma Proving Ground, AZ Pacific Northwest National Laboratory, June 2010 
APPENDIX E

\section{Analysis of Solar Opportunities}




\section{Appendix E: Analysis of Solar Opportunities}

\section{Solar Technology}

There is a wide range of solar technologies and applications available for energy generation. Solar technologies can be classified by the specific technique used for converting solar energy into useful energy for direct use as a substitute for a conventional energy source. Solar energy is unique in that the sun's energy, or insolation, can be captured to provide electrical energy, heating energy (solar thermal), or a combination of both.

\section{Solar Electric}

Solar electric collectors are either photovoltaic (PV) arrays or concentrating solar arrays. There are three major PV array subcategories, as follows:

* Flat Panel. Arrays of PV modules mounted on racks either at ground level or on rooftops at a fixed angle. Generally, this angle is equal to the location's latitude.

* Axis-Tracking. PV arrays can be mounted on an assembly that moves throughout the day and keeps the array positioned at an optimum angle to maximize the captured sunlight (Figure E1). An axis-tracking system can be either single- or dual-axis in nature. A single-axis tracking system typically has a fixed tilt that elevates the panel off the ground by an angle with respect to the north-south axis, and the

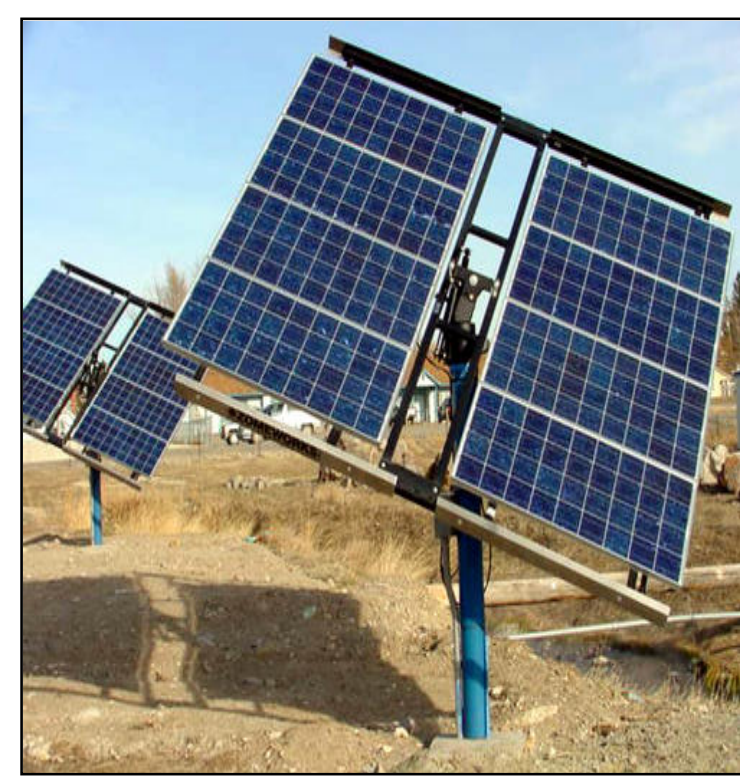

Figure E-1: Dual-Axis Tracking PV Array system is allowed to follow the sun's trajectory, the ecliptic, across the sky. Such a system can better optimize the insolation that strikes the panels. A dual-axis tracking system allows the panels to rotate along two axes, thereby truly maximizing the panel's ability to harvest solar energy. However, these systems are considerably more complex and impose additional operations and maintenance costs than flat panel assemblies.

* Integrated PV Panel. PV panels can also be integrated with building roofing material, which can provide a cleaner look than stand-alone panels. Integrated PV panels can come as replacements for standard shingles, metal standing-seam roofing, and membrane roofing for flat roofs (Figure E-2). The lack of tilt usually prevents the system from optimizing its electricity generation. However, the lower capital costs of these systems can make them more cost-effective than other PV

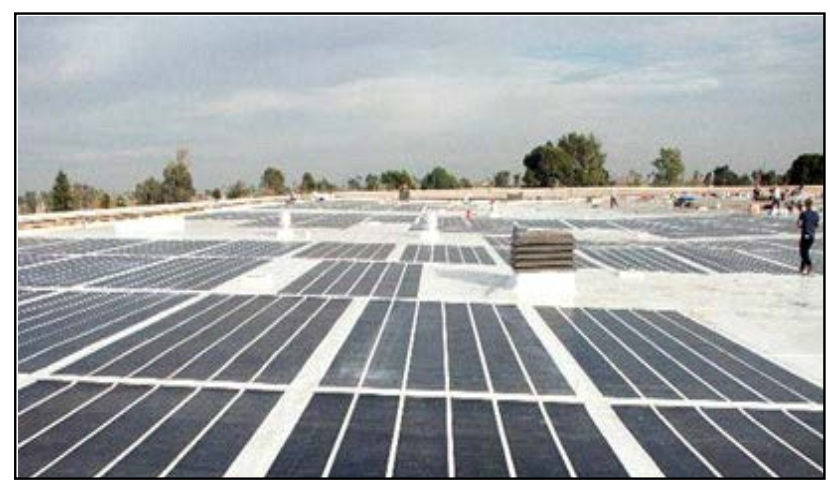

Figure E-2: Integrated PV on Rooftop systems. One problem with roof-mounted systems is that the panels can be easily obscured by snow or other detritus unless they are regularly cleaned. 
Concentrating solar power (CSP) systems use mirrors, lenses, and other optical devices to concentrate the sun's energy onto a receiver. The high temperatures generated by the focused sunlight can then be used for energy production. There are three primary configurations of thermal CSP systems:

* Solar Dish. A solar dish system employs an engine that is able to harvest thermal energy to generate electricity. These dualaxis tracking systems use dish-like concentrators to focus thermal energy on a point where a heat engine is mounted. Stirling engines are frequently used in solar dish applications. This engine is a mechanical device that uses heat flow to expand and contract a working gas that drives a piston and produces energy (Figure E-3). Most systems are on the order of several kilowatts to tens of kilowatts. In addition, turbine engines that operate on a Brayton cycle can use solar heat to cause gas expansion to produce power. Solar

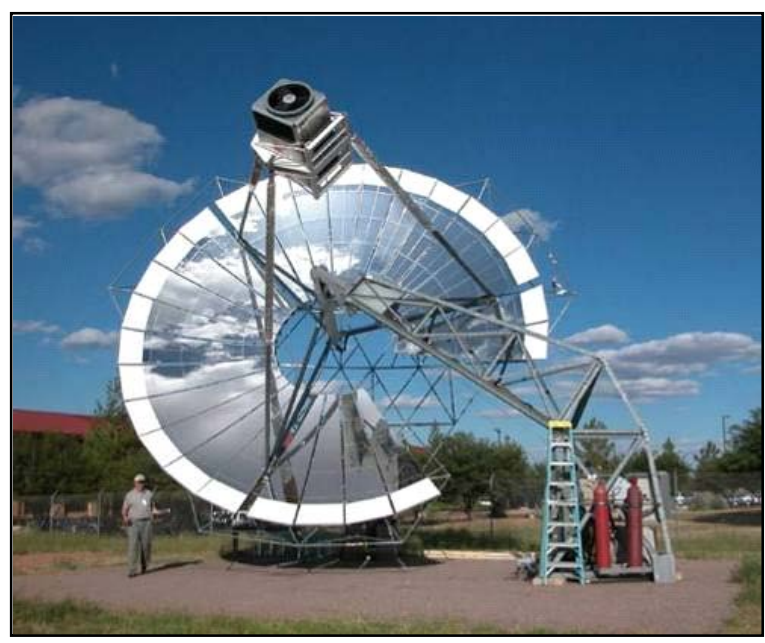

Figure E-3: Fort Huachuca Stirling Engine Solar Dish dishes that utilize the Brayton cycle can be modified to also run on a fuel such as natural gas. When operating as a hybrid system, the system’s capacity factor can approach 50\%. These hybrid systems are still experimental.

* Solar Power Tower. A solar power tower system uses very large arrays of mirrors, or heliostats, to concentrate the sun's energy on a central receiver tower to produce steam that drives a generator. Thermal storage allows the system to store excess thermal energy for use at dusk and into the evening. Most existing or planned commercial solar power tower plants are larger than $10 \mathrm{MW}$. Small-scale solar power towers on the order of $1 \mathrm{MW}$ have been constructed, but these are typically for research purposes and are not economically feasible.

* Solar Trough. When used for power generation, these large arrays concentrate the sun's energy onto a pipe containing a liquid that is used to generate steam that drives a generator. These systems always employ single-axis tracking mirrors or reflectors orientated along the north-south axis and are highly sensitive to the slope of the ground because of the need to pump the liquid through the collector tubes. Cogeneration and thermal storage are options for this technology as well. Solar trough plants are on the order of $40 \mathrm{MW}$ or larger.

Thermal CSP plants are still in various stages of development. In general, solar trough plants are the most advanced, while the solar dish and solar power tower systems are less mature. While thermal CSP plants are somewhat unproven compared to traditional PV plants, they have the potential to deliver large quantities of energy at a cost below that of PV. Thermal concentrating power systems were considered for this assessment because of available direct normal insolation is close to the 6.75 $\mathrm{kWh} / \mathrm{m}^{2} /$ day threshold typically cited for CSP viability. Direct normal insolation is a subset of the total insolation levels that excludes the indirect (diffuse) insolation that is reflected from clouds or the ground because this insolation cannot be concentrated. Based upon data from National Aeronautic and Space Administration's (NASA) Surface Meteorology and Surface Energy (SSE) 
Database, Yuma Proving Ground has an average direct normal insolation level of $6.66 \mathrm{kWh} / \mathrm{m}^{2} /$ day, which is slightly below the $6.75 \mathrm{kWh} / \mathrm{m}^{2} /$ day target.

Yuma Proving Ground is a relatively small installation with a small energy demand compared to most Army instillations. Consequently, most large-scale solar thermal technologies are oversized relative to Yuma Proving Ground's needs. Moreover, the Wellington-Mohawk Irrigation and Drainage District (WMIDD) is not obligated to purchase excess energy via a net metering arrangement. Given that the generating capacity of solar power tower and solar trough plants are several times larger than the maximum demand of Yuma Proving Ground, the lack of a compulsory net metering policy, and the need for utility cooperation, it is not recommended that this facility pursue large-scale solar thermal power plants at this time. Solar dishes, however, are smaller in scale and may be feasible at Yuma Proving Ground under the right conditions.

Lastly, concentrating PV (CPV) is beginning to gain attention as well. In a CPV system, mirrors and/or lens focus sunlight onto a small area of PV material. Typically, this PV material is more sophisticated and costs more than the PV material used in most conventional solar cells. However, these advanced PV cells are also more efficient and are capable of absorbing insolation levels equivalent to dozens to hundreds of suns. This technology is promising because it may lead to low cost solar energy because of reduced system materials cost. While there are a several commercial, small-scale CPV arrays and a handful of medium-scale utility demonstration projects, this technology is still too immature to consider for utilization at Yuma Proving Ground.

\section{Solar Thermal}

Rather than electricity as the end product, solar energy can also be used to directly heat air, water that is used for space heating, or water that is used for service hot water (SHW) or swimming pools. Solar thermal collectors can take many forms, including transpired solar collectors (TSCs, also known as solar walls), solar troughs for hot water heating, flat-plate collectors, and evacuated-tube collectors. These solar energy systems can be cost-competitive even when PV is not. Also, the Arizona RPS covers a wide range of solar technologies including solar space heating (e.g., solar walls), solar pool heating, solar water heating, solar cooling, and others. However, solar thermal projects do not count towards the EPAct mandate.

TSCs (Figure E-4) can be a cost-effective technique of using solar energy to preheat air for space heating or industrial processes. This heated air is drawn into a heating or ventilation system and can provide a portion of a building's heating demand. When an existing HVAC

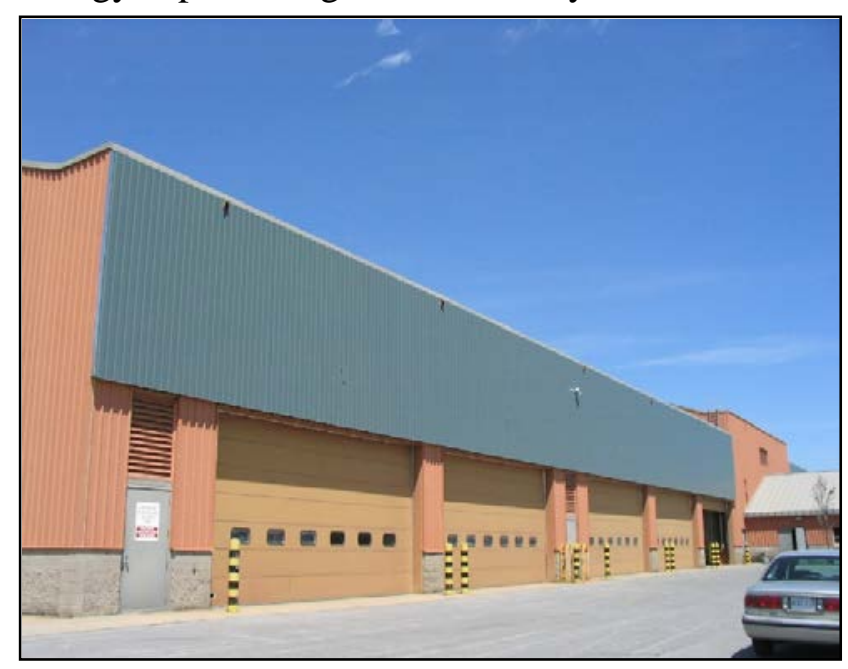

Figure E-4: Transpired Solar Collector at Fort Drum

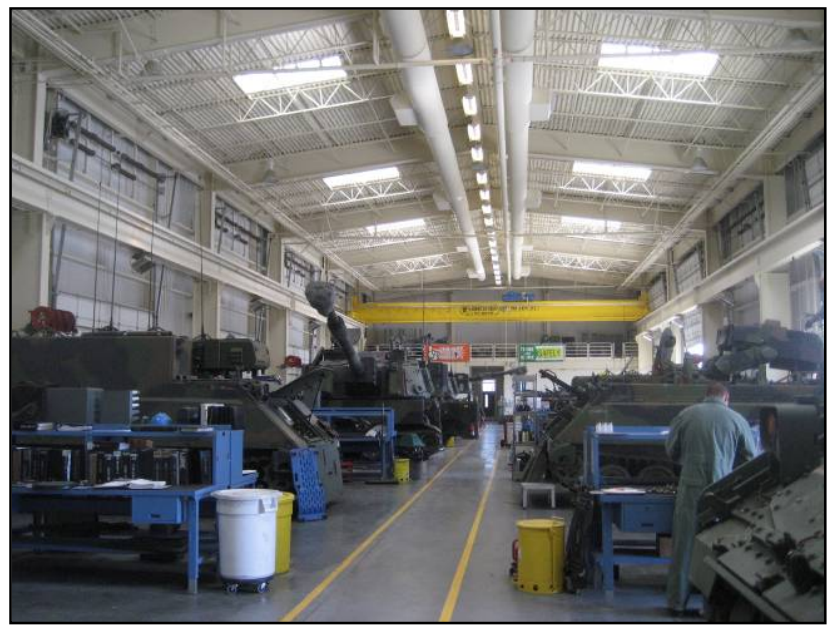

Figure E-5: Daylighting Fixtures at Yakima Training Center 
system is incapable of integrating with a TSC, it is common to install a network of cloth ducts that can distribute the solar heated air. When predicting the amount of heating load that a TSC can displace from the existing heating system, it is important to take into account the times of the year when the TSC is capable of producing heat, but no heat is actually needed for the building.

Daylighting fixtures (Figure E-5) are also becoming an increasingly important part of energy management. Modern versions of traditional skylights have better insulating properties and light dispersion. Light shelves, atriums, and solar tubes are other examples of daylighting fixtures (Figure E-5). Again, these are solar-based systems that can offset electricity consumption when properly implemented, but they do not generate electricity themselves. Although daylighting retrofits can be economic, daylighting is most cost-effective when implemented during a building's planning phase. Like the above-mentioned solar thermal technologies, daylighting technologies do not count towards the EPAct mandate.

Solar technologies can be further categorized by their scale. Large-scale solar projects can be massive in scope with hundreds of collectors and an energy output expressed in hundreds of kilowatts. Smaller-scale projects, often at the building level, are also possible and may be more desirable because of land area limitations, aesthetics considerations, or for energy security. Certain solar technologies, like PV, can be either large-scale or small-scale, while technologies like TSCs are only found at the building level. Thermal CSP projects are typically large scale.

\section{Existing Solar Projects}

There are several PV projects at Yuma Proving Ground including:

- A $450 \mathrm{~kW}$, utility-tied PV system

- A $225 \mathrm{~kW}$, remote, off grid facility for lighting

- A $105 \mathrm{~kW}$ facility for supporting remote testing, cameras, and instrumentation

- A large PV array for vehicle battery charging that is no longer in use

- A several hundred $\mathrm{kW}$ array that serves also functions as a cover over a parking lot

- Various smaller-scale PV projects.

In addition, Yuma Proving Ground has been the location for several test/research PV projects and has formed partnerships with utilities for PV installation.

\section{Solar Analysis Approach}

The analytic approach for the solar energy assessment consists of the following steps:

- Identify solar potential-Use established sources to determine seasonal and annual solar radiation for the site.

- $\quad$ Determine utility perspective-Obtain electric rate tariff information, evaluate state and local regulations, and identify grants, incentives, and other support.

- Identify potential development areas-Study existing electrical transmission system and identify installation-specific sites and potential users of generated energy.

- $\quad$ Determine applicable solar technology - Evaluate solar electric technologies including both large-scale (approximately $500 \mathrm{~kW}$ to 5+ MW) applications, such as an array of groundmounted PV panels, and small-scale (30 kW to $500 \mathrm{~kW}$ ) applications, such as roof-mounted PV systems. 
- Develop project economics-Determine project capital investment requirements, project operations and maintenance costs, and estimate economic value of expected electric production based on selected solar technology and market prices.

\section{Solar Resource Characterization}

The American Southwest typically experiences insolation levels on the order of 5 to over $6.5 \mathrm{kWh} / \mathrm{m}^{2} / \mathrm{day}$. From a resource perspective, Yuma Proving Ground is well positioned to take advantage of this relatively bountiful solar resource because it is located in an area of the Southwest with a particularly high resource (Figure E-6: note that this map displays global insolation and not direct normal insolation).

The solar resource potential was estimated using the solar potential estimates in the NASA's SSE database and Natural Resources Canada's RETScreen analysis software. The SSE data set is a continuous and consistent 10-year

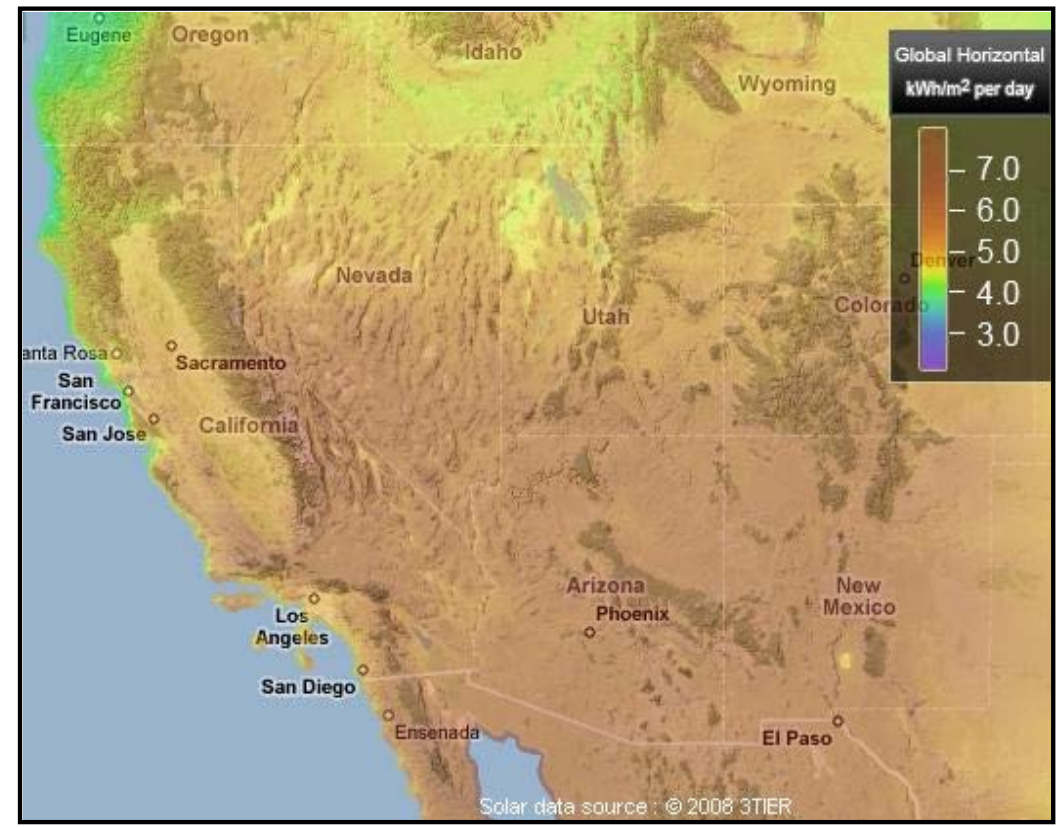

Figure E-6: Solar Insolation Levels for the South East Region, 3Tier FirstLook Solar Resource Map global climatology of insolation and meteorology data on a $1^{\circ}$ by $1^{\circ}$ grid system. Although the SSE data within a particular grid cell are not necessarily representative of a particular microclimate or point within the cell, the data are considered to be the average over the entire area of the cell. That estimate should be sufficiently accurate for preliminary feasibility studies of new renewable energy projects. In addition, the SSE database provides year-to-year variability in terms of 10-year maximums and minimums for a number of parameters.

In Table E-1, the average solar insolation data is shown for several different surface orientations including: a flat roof surface, a flat panel with a tilt equal to the latitude, a dual-axis tracking panel, and a flat, wall-mounted panel. Average monthly insolation values are provided in $\mathrm{kWh} / \mathrm{m}^{2} /$ day for the following conditions:

- Tilt 0 - Collector installed at a $0^{\circ}$ tilt (i.e., on a flat surface such as a roof)

- Tilt (lat-15) - A tilt of latitude minus $15^{\circ}$ would favor energy production in the summer when the sun is higher

- $\quad$ Tilt lat - Tilting a PV array at an angle equal to the latitude is a generally accepted way to optimize annual electricity production

- Tilt (lat+15) - A tilt of latitude plus $15^{\circ}$ would favor energy production in the winter when the sun is lower

- Tilt 90 - Collector installed against a vertical surface (i.e., wall)

- Tilt Optimal - Collector whose tilt angle is set an optimal angle for each month thereby increasing its insolation intensity 
- Optimal Angle - This is the optimal tilt angle, in degrees, for each month of the year between the plane of the array and the ground

- Dual-Axis Tracking - Collector capable of tracking the sun's zenith and azimuth angle over the course of the day thereby maximizing its insolation value.

Table E- 1: Monthly Averaged Insolation Incident on an Equator-Pointed Tilted Surface at Yuma Proving Ground (kWh/m²/day)

\begin{tabular}{|l|c|c|c|c|c|c|c|c|c|c|c|c|c|}
\hline & Jan & Feb & Mar & Apr & May & Jun & Jul & Aug & Sep & Oct & Nov & Dec & $\begin{array}{c}\text { Annual } \\
\text { Average }\end{array}$ \\
\hline Tilt 0 & 3.24 & 4.27 & 5.54 & 7.08 & 8.02 & 8.36 & 7.62 & 7.06 & 6.09 & 4.89 & 3.61 & 2.97 & 5.73 \\
\hline Tilt 18 & 4.29 & 5.18 & 6.23 & 7.39 & 7.86 & 7.96 & 7.36 & 7.17 & 6.65 & 5.86 & 4.71 & 4.03 & 6.23 \\
\hline Tilt 33 & 4.91 & 5.63 & 6.45 & 7.22 & 7.33 & 7.26 & 6.79 & 6.86 & 6.72 & 6.33 & 5.34 & 4.68 & 6.29 \\
\hline Tilt 48 & 5.24 & 5.78 & 6.32 & 6.66 & 6.41 & 6.18 & 5.88 & 6.20 & 6.44 & 6.44 & 5.67 & 5.05 & 6.02 \\
\hline Tilt 90 & 4.59 & 4.53 & 4.26 & 3.53 & 2.73 & 2.38 & 2.47 & 3.04 & 3.98 & 4.90 & 4.85 & 4.54 & 3.82 \\
\hline $\begin{array}{l}\text { Tilt } \\
\text { Optimal }\end{array}$ & 5.3 & 5.78 & 6.45 & 7.39 & 8.03 & 8.39 & 7.62 & 7.19 & 6.74 & 6.44 & 5.71 & 5.14 & 6.68 \\
\hline $\begin{array}{l}\text { Tilt } \\
\text { Angle } \\
\text { (degrees) }\end{array}$ & $57^{\circ}$ & $47^{\circ}$ & $35^{\circ}$ & $19^{\circ}$ & $3^{\circ}$ & $0^{\circ}$ & $0^{\circ}$ & $13^{\circ}$ & $29^{\circ}$ & $45^{\circ}$ & $55^{\circ}$ & $60^{\circ}$ & $30^{\circ}$ \\
\hline $\begin{array}{l}\text { Dual Axis } \\
\text { Tracking }\end{array}$ & 6.31 & 6.95 & 8.47 & 9.78 & 11.25 & 11.46 & 10.29 & 10.04 & 8.91 & 8.46 & 6.85 & 6.08 & 8.74 \\
\hline $\begin{array}{l}\text { Direct } \\
\text { Normal } \\
\text { Insolation }\end{array}$ & 5.43 & 5.78 & 6.88 & 7.68 & 8.24 & 8.43 & 7.38 & 6.36 & 6.45 & 6.06 & 5.87 & 5.33 & 6.66 \\
\hline
\end{tabular}

The solar resource data for Yuma Proving Ground shown in Table E-2, shows that a flat collector tilted at $33^{\circ}$ (Tilt lat) has an average yearly solar potential of $6.29 \mathrm{kWh}_{\mathrm{solar}} / \mathrm{m}^{2} /$ day. A dual-axis tracking PV array will receive $8.74 \mathrm{kWh}_{\text {solar }} / \mathrm{m}^{2} /$ day of incident solar radiation. Figure E-7 shows this incident solar radiation on a flat roof surface $\left(0^{\circ}\right.$ tilt), a fixed array (latitude tilt), a dual-axis tracking array, and a wall-mounted system ( $90^{\circ}$ tilt) at Yuma Proving Ground. 


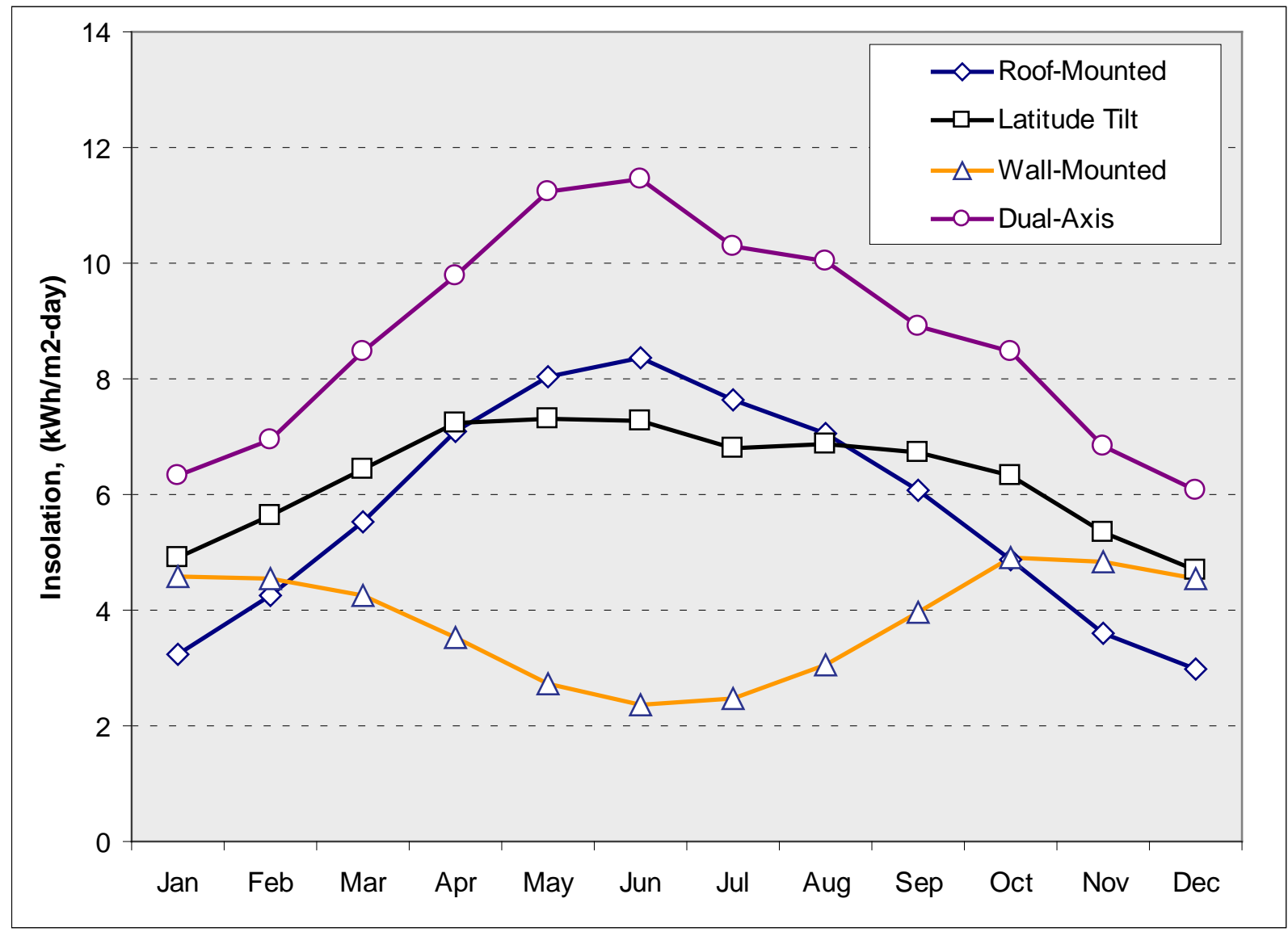

Figure E-7: Average Daily Insolation at Yuma Proving Ground

\section{Siting Considerations for PV and CSP Technologies}

Compared to most renewable energy technologies, PV panels and small-scale CSP systems have a fair degree of siting flexibility. As previously mentioned, an array can be mounted on the ground or upon existing buildings and structures. Potential site needs to be free of any objects, such as trees or buildings, which may cast a shadow on the array. Also, the system will require an inverter to convert the DC power output into AC power. Inverters can be located indoors or outdoors, although indoor locations will provide more shelter and help ensure inverter longevity and performance. Moreover, for larger-scale projects of $25 \mathrm{~kW}$ or more, it is common to use multiple inverters to optimize the system's efficiency as well as provide redundancy. If any projects of this scale were considered, space would need to be secured for the inverter bank.

A typical 1-kW PV array may range in size from 8 to $9 \mathrm{~m}^{2}$; however, a larger array requires access space as well as spacing between the rows of panels to avoid self-shading and will subsequently require a greater amount of space per installed $\mathrm{kW}$. For example, a 30-kW array would likely require $550 \mathrm{~m}^{2}$, and a $100-\mathrm{kW}$ array may require nearly $2000 \mathrm{~m}^{2}$, assuming that the PV array occupies $50 \%$ of the space. Panels mounted on slanted roofs can usually be more tightly grouped because of a decrease in self-shading potential. In addition, large arrays can produce considerable amounts of energy and require siting near existing high voltage power lines. Solar dish systems typically require $110 \mathrm{~m}^{2}$ per dish and can be sited in a wide variety of locations provided there are no shade-casting objects and there is access to power lines. 
Roof-integrated PV systems are ideal when there is only a minimal amount of available ground space or when a building's roof is in need of replacement. Although roof sited PV systems frequently require the installation of PV panels at non-optimized angles because of roof slopes and orientations, roof-integrated PV can be an attractive option because of its relatively low cost and its ability to securely generate energy for mission-critical buildings.

Yuma Proving Ground appears to have abundant open space for ground-mounted PV or CSP arrays. Possible sites that appear to have sufficient open space and are relativity free from shading include:

- In the surrounding space near the existing $450 \mathrm{~kW}$ array off a $12.47 \mathrm{kV}$ line

- In the several empty lots in the MTD ROC near a $12.47 \mathrm{kV}$ line that lead to substation B

- In the surrounding space near Building 2970 off a $34.5 \mathrm{kV}$ line

- Between Substation H and Building 3185 near a $12.47 \mathrm{kV}$ line

- In the large empty area due east of Building 3504 near a $12.47 \mathrm{kV}$ line

In general, there are additional spaces spread throughout Yuma Proving Ground that are also near high voltage lines. The terrain is generally flat and would require minimal grading. The primary disadvantages of these areas is their distance from the main post and testing areas, which will increase travel and construction time as well as potential mission impact. The abundance of available space near the cantonment area and the primary testing areas suggests that considering more remote areas will not be necessary.

\section{Findings: Solar Electric Production}

A flat collector tilted at an angle equal to the latitude $\left(33^{\circ}\right)$ has an average yearly solar potential of $6.29 \mathrm{kWh}_{\text {solar }} / \mathrm{m}^{2} /$ day at Yuma Proving Ground. Solar conversion is an inefficient process; typical PV cells have a conversion efficiency ranging from $10 \%$ to $16 \%$. Whereas solar potential is expressed in $\mathrm{kWh}_{\text {solar }} / \mathrm{m}^{2}$, PV array production is generally expressed as annual energy produced per rated $1 \mathrm{~kW}$ of PV array. Taking into account the annual solar potential and the efficiency of a typical PV system, each $\mathrm{kW}$ of installed PV would be expected to produce 1,790 $\mathrm{kWh}_{\text {electric }}$ at Yuma Proving Ground. The system would have a capacity factor of $20.4 \%$.

An axis-tracking PV array can produce $30 \%$ to $40 \%$ more energy than a stationary PV array, resulting in a higher output per unit surface area, and has a much flatter energy output profile during the day. The tracking racks increase the cost of installation by approximately $\$ 1$ to $\$ 2$ per installed watt. An axis-tracking array would produce 3,190 $\mathrm{kWh}_{\text {electric }}$ annually per $1 \mathrm{~kW}$ of installed PV capacity at Yuma Proving Ground. The system would have a capacity factor of $28.2 \%$.

Building-integrated solar products such as standing seam roofs and integrated roof-membrane PV should be considered for new construction and major renovations where cost savings can be leveraged. For example, if a roof needs to be replaced, the replacement would be an avoided cost for the solar project. An integrated roof-membrane PV product installed on a flat roof at Yuma Proving Ground would be expected to produce 2,090 kWhelectric annually per $1 \mathrm{~kW}$ of installed capacity. The system would have a capacity factor of $19.8 \%$. Satellite imagery shows that the five largest viable roofs on post have approximately 4,000 square meters of open roof area that could host approximately $297 \mathrm{~kW}$ of integrated roof-membrane PV material, which would produce approximately $515 \mathrm{MWh}_{\text {electric }}$ annually. 
Table E-2 lists the five largest, viable building rooftops on Yuma Proving Ground considered in this study. It was assumed that only $50 \%$ of the rooftop space would be available for PV modules because of commonly encountered roof obstructions such as HVAC systems or vents, the need to preserve access paths across the roof, and shading from nearby buildings, trees, and parapet walls.

Table E- 2: Roof-Integrated Membrane PV Analysis at Yuma Proving Ground

\begin{tabular}{||l|c|c|c||}
\hline \hline $\begin{array}{l}\text { Building } \\
\text { Number }\end{array}$ & $\begin{array}{c}\text { Viable Roof } \\
\left.\text { Area } \mathbf{( m}^{\mathbf{2}}\right)\end{array}$ & $\begin{array}{c}\text { Potential Installed } \\
\text { Capacity (kW) }\end{array}$ & $\begin{array}{c}\text { Energy Output } \\
\text { (MWh/yr) }\end{array}$ \\
\hline $\mathbf{3 4 9 0}$ & 1,462 & 110 & 190 \\
\hline $\mathbf{5 3 6}$ & 833 & 63 & 110 \\
\hline $\mathbf{3 2 9 4 / 3 2 9 6}$ & 798 & 60 & 105 \\
\hline $\mathbf{5 1 1}$ & 503 & 38 & 65 \\
\hline $\mathbf{5 1 9}$ & 374 & 26 & 45 \\
\hline \hline Total & $\mathbf{3 , 9 6 9}$ & $\mathbf{2 9 7}$ & $\mathbf{5 1 5}$ \\
\hline
\end{tabular}

The solar dish is the most efficient thermal CSP technology, but has the lowest capacity factor of the solar thermal technologies because of its lack of thermal storage capabilities. One $25 \mathrm{~kW}$ dish should produce about 45 MWh per year at Yuma Proving Ground and would have a capacity factor of 21\%. About $110 \mathrm{~m}^{2}$ of land is required per dish including some buffer area between dishes if multiple dishes were to be installed. If Yuma Proving Ground desired to deploy a small-scale thermal CSP plant, solar dishes would be the only feasible option. However, solar dishes are also an option for large-scale solar plants and have the flexibility of starting small and adding additional capacity over the years. In 2006, a Black \& Veatch study found that the solar dish technology is at a precommercial status because current systems have not demonstrated the level of reliability considered necessary for commercial systems (Stoddard et al. 2006). However, Southern California Edison has recently entered into a contract to develop a 500-MW Stirling engine solar dish array in Southern California, which suggests that under the right regulatory and economic conditions, the solar dish technology may be commercially feasible.

A summary of the solar electric information can be found in Table E-3.

Table E- 3: Solar Electric Production by System Type at Yuma Proving Ground

\begin{tabular}{|c|c|c|c|c|c|}
\hline System Type & $\begin{array}{l}\text { Assumed } \\
\text { PV Module } \\
\text { Efficiency }\end{array}$ & $\begin{array}{l}\text { Solar Insolation, } \\
\mathbf{k W h}_{\text {(solar) }} / \mathbf{m}^{2} / \mathbf{y r}\end{array}$ & $\begin{array}{c}\text { Electric } \\
\text { Production, } \\
\mathbf{k W h}_{\text {(electric) }} / \mathbf{y r}\end{array}$ & $\begin{array}{c}\text { Specific } \\
\text { Yield, } \\
\left(\mathbf{k W h} / \mathbf{m}^{2}\right)\end{array}$ & $\begin{array}{c}\text { Capacity } \\
\text { Factor }\end{array}$ \\
\hline $\begin{array}{c}1 \text { kW South-Facing, } \\
33^{\circ} \text { Tilt }\end{array}$ & $11.00 \%$ & 2,300 & 1,790 & 196.9 & $20.4 \%$ \\
\hline $\begin{array}{c}1 \mathrm{~kW} \text { Integrated Roof } \\
\text { Membrane }\end{array}$ & $7.60 \%$ & 2,090 & 1,739 & 132.1 & $19.8 \%$ \\
\hline $\begin{array}{c}1 \text { kW Dual-Axis } \\
\text { Tracking }\end{array}$ & $11.00 \%$ & 3,190 & 2,473 & 272.0 & $28.2 \%$ \\
\hline 25 kW Solar Dish & $25 \%$ & 2,460 & 45,000 & 576.9 & $20.5 \%$ \\
\hline
\end{tabular}




\section{Findings: Solar Project Economics}

Based on current average solar system costs and the projected performance for the various solar system configurations, life-cycle costs were developed for solar technologies at Yuma Proving Ground under two funding scenarios: appropriated, using Energy Conservation Investment Program (ECIP) funds and third party financing via an independent power producer (IPP). Cost-effectiveness for ECIP projects is determined with savings-to-investment ratio (SIR) values while the internal rate of return (IRR) shows whether the IPP scenario is cost-effective. Third-party financing utilizes a third party to develop, fund, and install the projects under a power purchase agreement (PPA) or other vehicle. The third party, being a private company or utility, could take advantage of tax credits for renewable energy projects and may also sell the renewable energy credits (RECs), which in turn lower the cost required to pay for the electricity. Building-integrated PV can also be developed by a third party to take advantage of government incentives.

Yuma Proving Ground's energy sourcing is primarily from WAPA via the WMIDD as well as some supplemental energy from Arizona Public Services (APS). However, the vast majority of the energy is from WMIDD. Solar PV arrays and solar dish arrays are generally no larger than several hundred kilowatts, and they are not capable of providing baseload power. Moreover, because solar system energy production peaks during the daytime and is larger in the summer than in the winter, it is likely that the energy produced by a solar system would offset the supplemental purchased energy from the WMIDD (under contract number 98-DSR-10865), which is valued at 4.686 this value was used when evaluating the project economics.

Despite the strong solar resource, none of the solar systems are cost-effective at this time if the 4.686 per $\mathrm{kWh}$ is displaced. The combination of low-cost energy and high system capital costs is the principle barrier to economically viable solar power generation at Yuma Proving Ground. The SIR and simple payback for the ECIP scenario, the cost of electricity at a $10 \%$ IRR for the third-party financing scenario, and the breakeven system cost are shown in Table E-4 for each technology. Note, the cost of electricity at a $10 \%$ (internal rate of return) IRR is the cost of electricity that would be required to yield a $10 \%$ IRR at the assumed system prices. The breakeven system cost is the system cost per $\mathrm{kW}$ that would be required to yield a $10 \%$ IRR at the current electric rate. 
Table E- 4: Economic Results for Solar Technologies at Yuma Proving Ground

\begin{tabular}{||l|c|c|c|c||}
\hline & $\begin{array}{c}\text { Ground-Mounted } \\
\text { Fixed-Tilt PV }\end{array}$ & $\begin{array}{c}\text { Ground-Mounted } \\
\text { Axis-Tracking PV }\end{array}$ & $\begin{array}{c}\text { Building-Integrated } \\
\text { Roof-Mounted PV }\end{array}$ & Solar Dish \\
\hline Analyzed System Size & Greater than $250 \mathrm{~kW}$ & Greater than $250 \mathrm{~kW}$ & Greater than $250 \mathrm{~kW}$ & $25 \mathrm{~kW}$ \\
\hline $\begin{array}{l}\text { Equipment Cost } \\
\text { Assumptions (\$/kW) }\end{array}$ & $\$ 6,450$ & $\$ 7,800$ & $\$ 5,550$ & $\$ 4,700$ \\
\hline SIR & 0.178 & 0.214 & 0.199 & 0.0 \\
\hline Simple Payback (yr) & 76.1 & 63.5 & 67.7 & 278 \\
\hline $\begin{array}{l}\text { Cost of Electricity at } \\
\mathbf{1 0 \%} \text { IRR (4/kWh) }\end{array}$ & 35.0 & 30.5 & 31.0 & 28.0 \\
\hline $\begin{array}{l}\text { Breakeven System Cost } \\
\text { at 10\% IRR (\$/kW) }\end{array}$ & $\$ 750$ & $\$ 1,090$ & $\$ 730$ & $\$ 164$ \\
\hline Variable O\&M (c/kWh) & - & - & $\$ 12$ & $\mathbf{4} 2.6$ \\
\hline Fixed O\&M (\$/net kW) & $\$ 12$ & $\$ 12$ & $\$ 25$ \\
\hline
\end{tabular}

In-depth REC Market Potential Analysis

Yuma Proving Ground has expressed interest in exploring the opportunity of using a third party to develop renewable energy infrastructure for the purposes of REC selling. This arrangement would be much like the existing arrangement with Fort Carson. Fort Carson was able to install a solar PV project with the help of REC sales at 22 $4 / \mathrm{kWh}$.

To take advantage of the REC sales as well as the State and Federal tax incentives, a PV array would likely have to be installed via a PPA arrangement. Parties interested in establishing such an arrangement have approached Yuma Proving Ground in the past. In addition, Yuma Proving Ground may be interested in soliciting potential renewable energy generation projects that take advantage the DG REC market in Arizona. Although the current APS RFP has lapsed, other RFPs may be offered in the future. Consequently, Yuma Proving Ground should consider preparing a "Notice of Opportunity" (NO) for developers that may be interested in developing renewable energy projects on Yuma Proving Ground lands contingent on release of a new RFP. However, Yuma Proving Ground should be aware that the net amount of energy APS provided during FY 08 was $930 \mathrm{MWh}$, which while sizeable, was small compared to the energy provided by WAPA, which was 46,900 MWh. 930 MWh might not be a sufficiently large quantity of energy to attract a developer. This is further bolstered by the fact that the previous APS RFP required that a project be sized to produce at least 1,500 MWh per year. While this does not stipulate what APS may require in the future, APS is likely to have a similar limit in future RFPs.

Notice of opportunities (NOs) have not been used by DOD for renewable energy project implementation, but they can be structured in a manner that allows sites to effectively respond to RFPs. In this case, a NO could be a procurement vehicle that is used within the government to provide potential project bidders with a sufficient advance notice of a procurement action to prepare an adequate renewable energy generation proposal. Potential bidders would be provided the land use "opportunity" but the "development" opportunity would be contingent on the utility RFP process and not the responsibility of the government. Because the utility RFP process may not be fully known, the use of the land would also be contingent upon that schedule and any associated conditions it may impose. It would also provide a "right" to use the land contingent upon winning a utility contract 
(and any conditions the installation may impose on resource type, project scale and design, etc.). Ideally, the land use "right" would be granted to multiple firms to optimize the odds of hosting a winning supplier.

By using a NO, Yuma Proving Ground could prepare itself in anticipation of another RFP. If and when the RFP occurs, Yuma Proving Ground and the commercial partners would be prepared for RFP submittal. Because of the open nature of the NO, the entire process would be open and competitive. Moreover, by making development rights contingent upon winning the contract, Yuma Proving Ground would not be burdened with determining what it believes will be the most attractive proposal for the utility. This is especially beneficial because installation staffs are not experts in evaluating renewable technologies or bidder strengths both because they lack the domain expertise and because the evaluation criteria used by the utility are unknown to them.

Because of the RPS's DG clause, APS must procure DG RECs. Therefore, although APS only serves $2 \%$ of Yuma Proving Ground's total electrical supply, a similar analysis as above was performed to determine the value of energy at a 10\% IRR for PV technologies. The breakeven cost of electricity ranged from $18.3 \$$ per $\mathrm{kWh}$ to $22.8 \$$ per $\mathrm{kWh}$. This breakeven analysis included an assumed REC value of $18 \$$ per $\mathrm{kWh}$. At the lower end of the range at 18.3\$ per $\mathrm{kWh}$, REC sales of $18 \$$ per $\mathrm{kWh}$ came short of breaking even by $0.3 \$$ per $\mathrm{kWh}$, a value close enough to zero to be within error. On the other hand, at the higher end of the range at 22.8థ per kWh, REC sales of 18థ per kWh came short of breaking even by $4.8 \nsubseteq$ per $\mathrm{kWh}$. In general, the analysis suggests that at best, REC sales to APS would result in a breakeven scenario from an economic standpoint, and would allow for the installation of renewable energy infrastructure.

Given the area's growth, it is reasonable to expect that APS will, at a minimum, need to expand its REC purchasing at a value close to the rate mentioned above. Note, based upon PNNL's analysis of the previous RPS language and the grid maps provided, only the portion of energy, in $\mathrm{kWh}$, (not power, in MW) that APS provides Yuma Proving Ground would be eligible for the RFP. In other words, the size of the system will be limited to the aggregate amount of energy that Yuma Proving Ground purchases from APS, and it would have to be located on the northern portion of the facility. Depending on the system efficiency, the use of tracking technology, and/or the panel tilt, the system may range in size between approximately $350 \mathrm{~kW}$ to $550 \mathrm{~kW}$. Locating the array in the southern portion of the site may be challenging because of the apparent lack of direct interconnects between the two areas. If a southern location is desired, either Yuma Proving Ground will need to wheel the generated energy over WMIDD lines, or it will need to connect to certain APS lines that are located in the areas surrounding some of the southern portions of the site and along a portion of highway 95. Because the WMIDD is not bound by the RPS, it is unlikely that they will announce an RFP for DG RECs. In the case of another RFP, Yuma Proving Ground should verify (or request bidders to verify) whether or not the RFP will accept proposals that are sized larger than the net amount of energy APS delivers to the site.

The SIR and simple payback for the ECIP scenario, the cost of electricity at a $10 \%$ IRR for the thirdparty financing scenario, and the breakeven system cost are shown in Table E-5 for each technology. 
Table E- 5: Economic Results for Solar Technologies at Yuma Proving Ground when Displacing APS Power

\begin{tabular}{||l|c|c|c||}
\hline & $\begin{array}{c}\text { Ground-Mounted } \\
\text { Fixed-Tilt PV }\end{array}$ & $\begin{array}{c}\text { Ground-Mounted } \\
\text { Axis-Tracking PV }\end{array}$ & $\begin{array}{c}\text { Building-Integrated } \\
\text { Roof-Mounted PV }\end{array}$ \\
\hline Analyzed System Size & Greater than $250 \mathrm{~kW}$ & Greater than $250 \mathrm{~kW}$ & Greater than 250 kW \\
\hline $\begin{array}{l}\text { Equipment Cost } \\
\text { Assumptions (\$/kW) }\end{array}$ & $\$ 6,450$ & $\$ 7,800$ & $\$ 5,550$ \\
\hline SIR & 0.178 & 0.214 & 0.199 \\
\hline Simple Payback (yr) & 76.1 & 63.50 & 67.8 \\
\hline $\begin{array}{l}\text { Cost of Electricity at } \\
\mathbf{1 0 \%} \text { IRR (\$/kWh) }\end{array}$ & 22.80 & 17.60 & 3,810 \\
\hline $\begin{array}{l}\text { Breakeven System Cost } \\
\text { at 10\% IRR (\$/kW) }\end{array}$ & 3,930 & 5,480 & - \\
\hline Variable O\&M (c/kWh) & - & - & $\$ 12$ \\
\hline Fixed O\&M (\$/net kW) & $\$ 12$ & $\$ 12$ & \\
\hline
\end{tabular}

Ultimately, if Yuma Proving Ground pursues PV development via a PPA, the value of the REC is only a secondary concern. Typical PPAs result in long term, fixed-price energy contracts that can span up to 20 years. The principle concern for Yuma Proving Ground should be the duration of the fixed price contract and the proposed cost of electricity the PPA would provide. Based upon information provided to Yuma Proving Ground and information included in the previous APS RFP (such as expected energy escalation rates), PNNL analyzed whether the net present value of a PPA contract at varying fixed rates would be in the best interest of Yuma Proving Ground. For this analysis, a PV array was sized to match the energy load provided by APS. This quantity of energy was then analyzed at three different utility rates (i.e., what Yuma Proving Ground currently pays for electricity) at three different fixed price energy rates (i.e., what Yuma Proving Ground would be offered in the PPA agreement). The three utility rates were $6.8 \$ / \mathrm{kWh}$ (the APS marginal cost rate), $2.9 \$ / \mathrm{kWh}$ (Yuma Proving Ground's blended energy rate), and $4.7 \mathrm{c} / \mathrm{kWh}$ (the cost of the more expensive "other power" energy). The three fixed price rates were $5 \mathrm{\$} / \mathrm{kWh}, 6 \mathrm{\$} / \mathrm{kWh}$, and $7 \mathrm{\$} / \mathrm{kWh}$, where 5 to $7 \mathbb{\$} / \mathrm{kWh}$ is a reasonable expected fixed price energy rate range for a PPA contract.

Based upon this analysis, even at $7 \mathrm{\$} / \mathrm{kWh}$, it is likely that it would be cost-effective for Yuma Proving Ground to offset the expensive APS energy. Displacing the lower cost $2.9 \$ / \mathrm{kWh}$ is never cost-effective even at the lowest fixed price energy rate. Lastly, displacing the more expensive 4.7 $\$ / \mathrm{kWh}$ might be cost-effective if the PPA provided Yuma Proving Ground a low rate such as $5 \$$ per kWh.

The underlying assumptions for this analysis assumed a 3.0\% discount rate, a 1.8\% general inflation rate, and a $0.5 \%$ annual electric inflation rate. The 3.0\% discount rate is a typical value used for net present value (NPV) calculation, while the $1.8 \%$ general inflation rate is based upon national statistics. Lastly, the $0.5 \%$ annual electric inflation rate is based upon commercial APS utility rates between 1995 and 2007. The details of this analysis and the underlying economic assumptions are detailed in Table E-6.

Lastly, note that solar thermal electrical power is also an eligible technology under Arizona's RPS and would likely qualify for future APS RFPs. 
Table E- 6: Economic Analysis for a Potential APS RFP

\begin{tabular}{|c|c|c|c|}
\hline Scenario: & \multicolumn{3}{|c|}{$\begin{array}{l}\text { Displacing } 100 \% \text { APS Energy: } \\
\text { APS Energy Rate: } 6.8 \text { } \mathrm{c} / \mathrm{kWh}\end{array}$} \\
\hline PPA 20 year Fixed Rate & 5 \&/kWh & 6 \$/kWh & 7 \$/kWh \\
\hline $\begin{array}{l}\text { Yuma Proving Ground Current } \\
\text { NPV (\$) }\end{array}$ & $\$ 835,422$ & $\$ 835,422$ & $\$ 835,422$ \\
\hline Proposal NPV (\$) & $\$ 587,239$ & $\$ 704,687$ & $\$ 822,134$ \\
\hline Cost-effective? & Yes & Yes & Maybe \\
\hline Scenario: & \multicolumn{3}{|c|}{$\begin{array}{c}\text { Displacing } 100 \% \text { WAPA Energy: } \\
\text { WAPA Energy Rate: } 2.9 \text { \$/kWh }\end{array}$} \\
\hline PPA 20 year Fixed Rate & $5 \mathrm{c} / \mathrm{kWh}$ & $6 \mathrm{c} / \mathrm{kWh}$ & $7 \mathrm{c} / \mathrm{kWh}$ \\
\hline $\begin{array}{c}\text { Yuma Proving Ground Current } \\
\text { NPV (\$) } \\
\end{array}$ & $\$ 358,740$ & $\$ 358,740$ & $\$ 358,740$ \\
\hline Proposal NPV (\$) & $\$ 587,239$ & $\$ 704,687$ & $\$ 822,134$ \\
\hline Cost-effective? & No & No & No \\
\hline Scenario: & \multicolumn{3}{|c|}{$\begin{array}{l}\text { Displacing } 50 \% \text { WAPA Energy: } \\
\text { WAPA Energy Rate: } 4.67 \text { \$/kWh }\end{array}$} \\
\hline PPA 20 year Fixed Rate & $5 \mathrm{c} / \mathrm{kWh}$ & $6 \mathrm{c} / \mathrm{kWh}$ & 7 \$/kWh \\
\hline $\begin{array}{l}\text { Yuma Proving Ground Current } \\
\text { NPV (\$) }\end{array}$ & $\$ \$ \$ 573,739$ & $\$ 573,739$ & $\$ \$ \$ 573,739$ \\
\hline Proposal NPV (\$) & $\$ 587,239$ & $\$ 704,687$ & $\$ 822,134$ \\
\hline Cost-effective? & Maybe & No & No \\
\hline \multicolumn{4}{|c|}{ Economic Assumptions: } \\
\hline \multicolumn{2}{|l|}{ Real Discount Rate } & \multicolumn{2}{|c|}{$3.0 \%$} \\
\hline \multicolumn{2}{|l|}{ Inflation Rate } & \multicolumn{2}{|c|}{$1.8 \%$} \\
\hline \multicolumn{2}{|c|}{ Annual Electric Inflation Rate } & \multicolumn{2}{|c|}{$0.5 \%$} \\
\hline
\end{tabular}

\section{Solar: Next Steps}

Yuma Proving Ground has a high solar energy resource. Unfortunately, present project capital costs and current electric rates are not showing independent solar energy projects to be cost-effective at Yuma Proving Ground at this time. However, because of the presence of the RPS with a DG requirement, under a somewhat narrow set of circumstances (i.e., a PPA arrangement that displaces APS energy and/or where the PPA offers low, fixed electricity rate), a PV array may be costeffective. Attempting to displace a large fraction of Yuma Proving Ground's WAPA electricity was not found to be cost-effective. Finally, displacing the smaller portion of the higher cost WAPA electricity (valued at $4.67 \mathrm{\$} / \mathrm{kWh}$ ) may be cost-effective if the PPA provides relatively low cost electricity. Yuma Proving Ground should monitor future RFPs and consider drafting a notice of opportunity to solicit potential projects. Given the complexities of the economic transactions and energy price speculation required to analyze proposals, Yuma Proving Ground should consider seeking out additional assistance when evaluating these proposals.

Lastly, Yuma Proving Ground should continue to monitor the market conditions affecting solar energy. Advances in PV technology are expected to produce less expensive solar cells, although 
rising demand may negate some of the potential price drop. Rising energy rates may do the most to tip the scales in favor of solar electric. Probably the most important factor in making solar electric work at a Federal installation is identifying key partners - a private developer, a utility, or both - that can provide funding, capture tax incentives, purchase or market RECs, enter into PPAs, and provide other project support.

\section{Solar Sources of Information}

APS. 2006. "UCPP Working Group - Conforming Project Incentive Matrix.”

http://www.aps.com/files/rfp/2008DE_APS_Distributed_Energy_Administration_Plan_Project_Incentive _Matrix.pdf. Accessed July 2009.

Department of Energy (DOE). 1997. "Renewable Energy Technology Characterizations - December 1997 - Solar Parabolic Trough.” http://www1.eere.energy.gov/ba /pba/pdfs/solar_trough.pdf. Access November 2008.

Department of Energy (DOE). 1997. "Renewable Energy Technology Characterizations - December 1997 - Solar Power Tower.” http://www1.eere.energy.gov/ba /pba/pdfs/solar_tower.pdf. Access November 2008.

Department of Energy (DOE). 1997. "Renewable Energy Technology Characterizations - December 1997 - Solar Dish Engine.” http://www1.eere.energy.gov/ba /pba/pdfs/solar_dish.pdf. Accessed November 2008.

Emerging Energy Research, LTD. November 2007. “Global Concentrating Solar Power Markets and Strategies, 2007-2020.”

Lawrence Berkeley National Laboratory, February 2009. “Tracing the Sun: The Installed Cost of Photovoltaics in the U.S. from 1998-2007.” Berkeley, CA.

Minister of Natural Resources Canada. 1997-2008. RETscreen International Software Package, Clean Energy Decision Support Centre. http://www.retscreen.net.

Sargent \& Lundy Consulting Group. 2003. "Assessment of Parabolic Trough and Power Tower Solar Technology Cost and Performance Forecasts.” Chicago, IL.

Stoddard L, J Abiecunas, and R O'Connell. 2006. “Economic, Energy, and Environmental Benefits of Concentrating Solar Power in California.” Black \& Veatch. National Renewable Energy Laboratory. Overland Park, KS. NREL/SR-550-39291. April 2006. 


\section{APPENDIX F}

\section{Analysis of Wind Opportunities}




\section{Appendix F: Analysis of Wind Opportunities}

\section{Wind Technology}

There is a vast wind resource in the United States. The American Wind Energy Association states that domestic wind resources, which are economically feasible in at least 46 states, could theoretically supply all of the nation's electricity needs. At the current time, however, less than $1 \%$ of the nation's power is generated from wind. This situation is changing. In 2005 and 2006, wind was the second largest source of new electricity generation in the United States (AWEA 2007). In 2007, wind energy projects accounted for $30 \%$ of all the new energy capacity installed nationally (AWEA 2008).

Wind projects, often referred to as wind farms, can be categorized by scale. Large, utilityscale projects tend to be $50 \mathrm{MW}$ and above, with the world's largest single wind farm being the 735-MW Horse Hollow Wind Energy Center in Texas. Smaller projects (under 50 MW) are referred to as community wind projects or distributed generation (DG) projects.

Community wind projects involve local ownership structures, often with corporate partners taking advantage of the Federal production tax credit. DG projects are designed to offset the owner's retail electricity purchases by producing power that is used on-site, with surplus sold to a commercial utility.

Wind turbines come in many different sizes and configurations. Wind turbines in the U.S. generally employ the Danish configuration - a horizontal-axis, three-bladed rotor, an upwind orientation, and an active yaw system to keep the rotor oriented into the wind.

Utility-scale turbines for bulk power production tend to be $660 \mathrm{~kW}$ to $3 \mathrm{MW}$ in size. Hub heights can range from 50 meters (164 feet) to 80 meters (262 feet). Industrial turbines for consumer and remote grid production are found in the range of $50 \mathrm{~kW}$ to $250 \mathrm{~kW}$. Hub heights range between 25 meters ( 80 feet) and 40 meters (131 feet). Residential-scale wind turbines are used for remote power, battery charging, or net-metering generation. These turbines tend to be 400 watts to $50 \mathrm{~kW}$. For turbines greater than $1 \mathrm{~kW}$, the hub heights range from 12 meters (40 feet) to 36 meters (120 feet).

The land required for a single utility-scale wind turbine is typically 3 acres, including access roads, turbine base, and other equipment. A wind turbine located on a ridgeline in hilly terrain will require less area than one on flat land, as little as 2 acres per MW. The proper spacing of turbines is essential to reduce wake interference and optimize the wind resource. In open flat terrain, a utility-scale wind plant will require a buffer space of about 60 acres per MW of installed capacity.

Although more difficult to finance and lacking in economies of scale, smaller wind generation projects offer some potential benefits over large-scale wind farms:

- A smaller project is often easier to permit and may be less likely to interfere with other land uses (including military missions).

- On-site power generation that is integrated into the site electrical system provides energy security.

- It may be possible to avoid building a costly substation if a suitably sized power interconnection is located near a promising site for wind turbines. 


\section{Wind Analysis Approach}

\section{DoD Assessment Approach}

The DoD Renewables Study relied upon wind resource maps developed by the National Renewable Energy Laboratory (NREL), maps developed by independent companies, and PNNL's Wind Energy Resource Atlas of the United States to identify the installations with best potential for commercial-scale wind farms. The DoD analysis used the highest resolution map available for each state to quantify the wind resource on the military land in that state. Over 70 Army and Air Force installations were reviewed with respect to both wind resource and compatibility with the installation's mission. About 20 installations with potential for projects were selected for follow-on detailed assessments. Yuma Proving Ground was eliminated from further consideration and not selected for one of these assessments because of mission conflicts, limited wind resource potential, and challenging terrain features. These issues will be discussed further in the Siting Considerations section.

\section{Updated Wind Analysis Approach}

For this updated analysis, PNNL used the following approach to analyze the economic potential for wind energy at Yuma Proving Ground. More detail on the financing scenarios, generic analytic approach, and economic and other parameters used in this analysis are documented in Appendix A of this report.

(1) Wind resource maps and past studies were analyzed.

(2) Existing on-site interconnection and transmission capacity and availability were evaluated.

(3) Local wind developer activity in the area was surveyed to assess potential interest in developing projects.

(4) Available turbine models were evaluated to establish cost and performance parameters.

(5) Total project cost was estimated, including project development, generation equipment, balance of plant construction, interconnection and transmission, operation and maintenance (O\&M), taxes, and tax credits and other policy incentives.

(6) Economic feasibility was determined utilizing different financing scenarios: independent power producer (IPP) and Energy Conservation Investment Program (ECIP).

(7) Project feasibility was determined and next steps recommended.

\section{Wind Resource Characterization}

According to industry standards developed as part of the Wind Energy Resource Atlas of the United States, there are seven main classes of wind power, as shown in Table F-1. 
Table F- 1: Classes of Wind Power Density at 50 Meters

\begin{tabular}{|c|c|c||}
\hline $\begin{array}{c}\text { Wind } \\
\text { Power } \\
\text { Class }\end{array}$ & $\begin{array}{c}\text { Wind Power } \\
\text { Density, } \\
\text { W/m } \mathbf{m}^{2}\end{array}$ & Speed, m/s (mph) \\
\hline $\mathbf{1}$ & $<200$ & $<5.6(12.5)$ \\
\hline $\mathbf{2}$ & $200-300$ & $5.6(12.5)-6.4(14.3)$ \\
\hline $\mathbf{3}$ & $300-400$ & $6.4(14.3)-7.0(15.7)$ \\
\hline $\mathbf{4}$ & $400-500$ & $7.0(15.7)-7.5(16.8)$ \\
\hline $\mathbf{5}$ & $500-600$ & $7.5(16.8)-8.0(17.9)$ \\
\hline $\mathbf{6}$ & $600-800$ & $8.0(17.9)-8.8(19.7)$ \\
\hline $\mathbf{7}$ & $>800$ & $>8.8(19.7)$ \\
\hline
\end{tabular}

A strong Class 3 resource, preferably Class 4, is generally required to achieve an economic project on a large, commercial scale. According to the DoE's Arizona Wind Resource Map, Yuma Proving Ground has on average a Class 2 wind resource. This indicates that the wind resource at Yuma Proving Ground may not be sufficient to support a large-scale wind energy project.

To determine an average wind speed estimate for Yuma Proving Ground, the windNAVIGATOR wind-mapping tool from AWS Truewind was used. At 80 meters above ground, a typical hub height for commercial-scale turbines, the highest average annual wind speed found on-site is approximately 6.0 m/s (AWS Truewind 2009), as shown in Figure F-2.

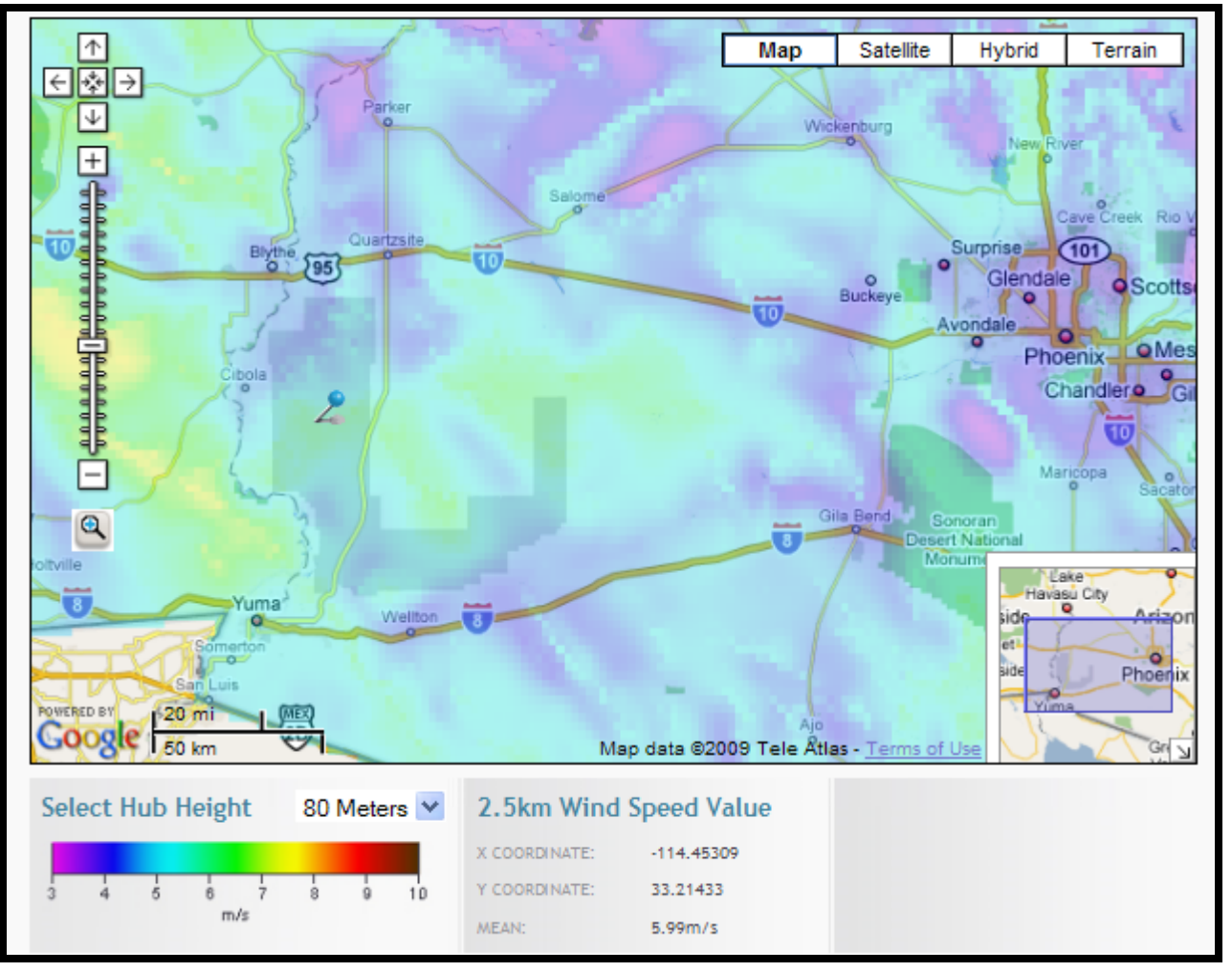

Figure F- 1: Highest Wind Speed on Yuma Proving Ground 
NASA's Langley Research Center Atmospheric Science Data Center was used as a reference comparison for Yuma Proving Ground's average wind speed. NASA Surface Meteorology and Solar Energy (SSE) provides data on a $1^{\circ}$ by $1^{\circ}$ grid system, based on wind speed data over a 10-year period from July 1983 to June 1993. According to this source, the annual average wind speed in the Yuma Proving Ground area is $4.81 \mathrm{~m} / \mathrm{s}$ at 50 meters (NASA 2008). Because this average wind speed is calculated for a large amount of land, the average is lower than what could be found at a given, specific location. The NASA SSE data also provides the monthly averaged air temperature at 10 meters above the surface of the Earth and the average atmospheric pressure. This information was utilized for calculating the wind energy's capacity factor.

Table F-2 summarizes Yuma Proving Ground’s wind resource.

Table F- 2: Summary of Wind Resource Data

\begin{tabular}{||c|l|l||}
\hline \multicolumn{1}{|c|}{ Location } & \multicolumn{1}{|c|}{ Source } & \multicolumn{1}{c|}{ Wind Speed } \\
\hline \multirow{3}{*}{ Yuma Proving Ground } & Wind Power Class & Class $2(5.6-6.4 \mathrm{~m} / \mathrm{s}$ at $50 \mathrm{~m})$ \\
\cline { 2 - 3 } & $\begin{array}{l}\text { windNAVITGATOR tool } \\
\text { from AWS Truewind }\end{array}$ & $6.0 \mathrm{~m} / \mathrm{s}$ at $80 \mathrm{~m}$ \\
\cline { 2 - 3 } & NASA SSE data & $4.81 \mathrm{~m} / \mathrm{s}$ at $50 \mathrm{~m}$ \\
\hline
\end{tabular}

\section{Siting Considerations}

The primary siting consideration for wind projects is transmission availability and the capacity of those lines. Projects need to be located within approximately 1 mile of existing transmission lines, or new lines will need to be constructed at considerable cost.

This analysis does not include any transmission costs and assumes that existing transmission lines are available to transmit power without substantial additional investment. It is also assumed that an on-site wind project would not trigger new standby or other fees from the local utility. But because wind is intermittent, the utility may have interconnection requirements to ensure grid stability and to ensure there is reliable power for the installation.

Another consideration is potential interference with airport operations. The Federal Aviation Administration (FAA) requires notice of proposed construction for a project that meets certain criteria so that it can determine if there would be adverse impacts to air navigation safety. One of the triggering criteria is whether the project would be located within 20,000 feet (3.8 miles) or less of an existing public or military airport. When selecting an area for a wind project, it would be best to avoid this potential interference issue by locating the project outside of the 20,000-foot range. Any wind project developed on-site would need to carefully consider this concern.

An additional FAA criterion triggering the notice of proposed construction is any construction or alteration of more than 200 feet (61 meters) in height above ground level. This criterion applies regardless of the distance from the proposed project to an airport. A determination of "No Hazard to Air Navigation" must be obtained from the FAA prior to constructing a wind project. 
As mentioned, Yuma Proving Ground was included at a preliminary level in the 2005 DoD

Renewables Study. Possible wind project locations were evaluated using range activity, road network access, transmission system access, and topography as criteria with the result being that only a few areas identified as having development potential. The potentially feasible, on-site project areas identified were the Castle Dome Area and land west of highway 95. The key benefit of these areas is transmission access. These areas are near both the existing 161$\mathrm{kV}$ WAPA-owned transmission line and a $69-\mathrm{kV}$ distribution line with substation. However, these areas also have a limited wind resource, challenging terrain, and may present mission conflicts with helicopter operations. This assessment should be revisited if mission activities or air operations have changed. For the purpose of conducting the economic assessment of this analysis, no specific location on-site was assumed.

\section{Wind: Economic and Other Analysis Parameters}

This assessment considered the current Federal wind incentives: a 2.1\$/kWh renewable energy production tax credit (PTC) and 5-year accelerated depreciation. State-specific incentives for Arizona are discussed in Appendix A.

During the original DoD renewable energy assessment in 2005, the installed cost of capital was approximately $\$ 1,400 / \mathrm{kW}$; at the current time, prices range from $\$ 1,700$ to $\$ 2,600 / \mathrm{kW}$ because of a worldwide turbine shortage and increased costs for components. The capital cost was assumed to be $\$ 2,212 / \mathrm{kW}$ (including incentives) for this economic assessment. Further details on the analysis methodology and the economic and incentive parameters are documented in Appendix A, and the assumptions used are listed in Table F-3.

Yuma Proving Ground has a low energy consumption rate because of the intermittent nature of the site's usage as well as its small on-site load. It also has two different electric rates. The average rate for the main charge is $\$ 0.0116 / \mathrm{kWh}$ and the "other power" charge rate is $\$ 0.04686 / \mathrm{kWh}$. The cost of electricity generated from wind energy cannot compete with the extremely low main charge rate and is unlikely to be competitive against the "other power" charge rate as well. Because of this and the assumption that a wind energy project would first offset energy purchased under the "other power" rate, the economic analysis examines the possibility of replacing this other power, and its associated charge rate, with wind energy.

Electricity consumption at this "other power" charge rate ranges from a high of about $2,500,000 \mathrm{kWh} /$ month to a low of about $230,000 \mathrm{kWh} / \mathrm{month}$. Based on the capacity factor calculations, detailed in Table F-3, it is estimated that one 1.5-MW turbine could produce $258,526 \mathrm{kWh} / \mathrm{month}$. This small project size was selected because it roughly matches the lowest monthly demand for the "other power" charge. Any more wind energy resource than the lowest monthly amount would have to compete against the other, low energy charges for that time period. 
Table F- 3: Performance, Cost, and Economic Characteristics

\begin{tabular}{|l|l|}
\hline Location & Yuma Proving Ground, Arizona \\
\hline Assumed Average Wind Speed & $6.0 \mathrm{~m} / \mathrm{s}$ at $80 \mathrm{~m}$ \\
\hline Capacity Factor & $24 \%$ \\
\hline Turbine Type & $1.5 \mathrm{MW}, 77 \mathrm{~m}$ rotor, $80 \mathrm{~m}$ hub \\
\hline Project Size & 1 turbine, $1.5 \mathrm{MW}$ total \\
\hline Estimated Annual Energy Production & $3,102,319 \mathrm{kWh} / \mathrm{yr}$ \\
\hline Energy Charge & $\$ 0.04686 / \mathrm{kWh}$ \\
\hline Total Capital Cost & $\$ 2,212 / \mathrm{kW}$ \\
\hline Fixed O\&M Cost & $\$ 60 / \mathrm{kW}$ \\
\hline 5-year accelerated depreciation & Included \\
\hline Federal 2.04/kWh PTC & Included \\
\hline RECs & Not Included \\
\hline Transmission Costs & Not Included \\
\hline
\end{tabular}

\section{Findings: Wind}

The various energy cost scenarios were evaluated for ECIP eligibility and IPP project potential. To qualify for ECIP funding, a project must achieve a savings-to-investment ratio (SIR) of 1.0, and its payback is also examined. For the IPP evaluation, the commercial cost of energy was calculated to obtain an internal rate of return (IRR) of $10 \%$. This was used as the minimum IRR required to attract the interest of a wind power project developer. Table F4 lists the results of these analyses.

Table F- 4: Economic Assessment of Wind Power

\begin{tabular}{|c|c|c|c|c||}
\hline $\begin{array}{c}\text { Financing } \\
\text { Scenario }\end{array}$ & $\begin{array}{c}\text { Energy } \\
\text { Cost } \\
(\mathbf{(} / \mathbf{k W h})\end{array}$ & IRR & ECIP SIR & $\begin{array}{c}\text { Simple Payback } \\
\text { (years) }\end{array}$ \\
\hline ECIP & 4.686 & $-8.9 \%$ & 0.17 & 69 \\
\hline IPP & 14.9 & $10 \%$ & n/a & n/a \\
\hline
\end{tabular}

Yuma Proving Ground's combination of a low cost of energy and a low wind resource results in an uneconomic wind energy project. For a potential wind energy project to achieve a $10 \%$ return, the electricity would have to be sold at $14.9 \$ / \mathrm{kWh}$, an unlikely rate.

\section{Wind: Next Steps}

As a result of the poor wind resource and unfavorable economics, Yuma Proving Ground should not pursue a large-scale wind power project.

However, several factors could change this conclusion. If the energy rates were to drastically increase, a wind project could become more economically attractive. Yuma Proving Ground currently enjoys low-cost power. The economic analysis of this report used the energy charge of $4.686 \$ / \mathrm{kWh}$. To reach a $10 \%$ IRR with the $6.0 \mathrm{~m} / \mathrm{s}$ wind speed, the energy rate would have to increase to $14.9 \$ / \mathrm{kWh}$. This is a huge rate increase and unlikely to happen, 
but adding the REC value to the rate may be one way to make up the difference. In this case, it would require a REC value of $10.214 \mathbb{\$} / \mathrm{kWh}$. Because of Arizona's RPS, this is a possibility, although the demand in the market and current pricing is not known.

The dictate of this assessment is to evaluate projects $1 \mathrm{MW}$ and larger in size. To facilitate this, the wind energy assessments are based on using the industry's current standard size wind turbine of $1.5 \mathrm{MW}$.

While Yuma Proving Ground does not have the wind resource to support a wind project, other installations with similar wind resources have implemented small-scale wind projects. For example, Fort Huachuca in Arizona has a wind energy project in place and a couple in development. There is a small $10-\mathrm{kW}$ wind turbine in Fort Huachuca's West Range that was installed in 2002. It has generated 1,400 to 5,200 kWh per year, with a maximum capacity factor of only $6 \%$. This extremely low capacity factor demonstrates the poor wind resource of the area. There are also plans to install a 50-kW Multiaxis Turbosystem (MAT), a new technology, from Mass Megawatts Wind Power using an ESPC contract. Fort Huachuca has also received ECIP funding for an $850-\mathrm{kW}$ wind turbine.

Information was not available on the economics of these projects, but it would be beneficial for Yuma Proving Ground to learn more about them if Yuma Proving Ground is interested in a small-scale wind project. Learning what, if any, incentives or other methods to reduce costs were used would be valuable.

To check the economics of a small-scale wind project at Yuma Proving Ground, a 100-kW project was considered. The installed cost for projects this size are approximately $\$ 4,500 / \mathrm{kW}$. Because of this high cost and Yuma Proving Ground's poor wind resource, a small-scale project would still not be economic.

While a wind project at Yuma Proving Ground is not recommended and would only contribute a small amount of electricity, it could provide other benefits. Installing a wind turbine can immediately bring attention from the local community to a site's commitment to renewable energy, if for no other reason than wind energy has become synonymous with "going green." Other considerations are that the cost of wind power is not dependent upon the cost of fossil fuels, and a wind project may provide a small level of energy security.

\section{References}

AWS Truewind. 2009. “windNAVIGATOR.” http://navigator.awstruewind.com/. Accessed May 2009.

American Wind Energy Association. 2007. "Wind Power Today." http://www.awea.org/pubs/factsheets/WindPowerToday_2007.pdf.

American Wind Energy Association. 2008. "Wind Power Outlook." http://www.awea.org/pubs/documents/Outlook_2008.pdf.

Federal Aviation Administration. 2007. Advisory Circular (AC 70/7460-1K) Obstruction Marking and Lighting. Effective: February 2, 2007.

http://www.airweb.faa.gov/Regulatory_and_Guidance_Library/rgAdvisoryCircular.nsf/0/b993dc dfc37fcdc486257251005c4e21/\$FILE/AC70_7460_1K.pdf. 
Global Energy Concepts, LLC. 2004. “U.S. Department of Defense Renewable Energy Assessment: Report of Wind Energy Potential On and Near Military Installations.” Prepared for NREL. Lowell, MA.

NASA Langley Research Center. 2008. "Surface meteorology and Solar Energy.” Atmospheric Science Data Center. http://eosweb.larc.nasa.gov/sse/. Accessed April 2009.

Pacific Northwest Laboratory. 1986. Wind Energy Resource Atlas of the United States. Prepared for Solar Technical Information Program \& Solar Energy Research Institute. Golden, Colorado. http://rredc.nrel.gov/wind/pubs/atlas/atlas_index.html.

Department of Energy and National Renewable Energy Laboratory. Arizona Wind Resource Map. http://www.windpoweringamerica.gov/images/windmaps/az_50m_800.jpg 


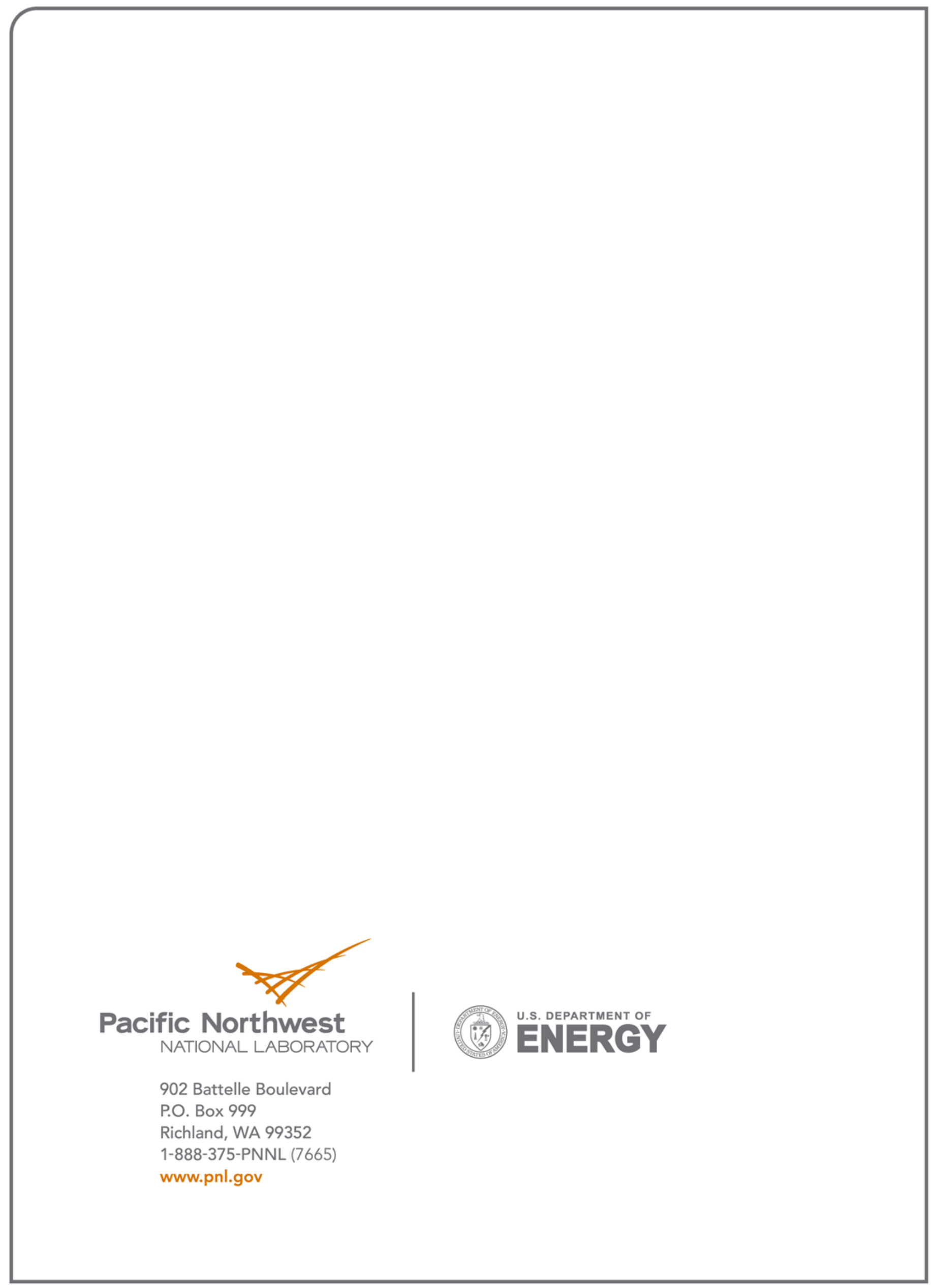

